\title{
West Virginia Title I Elementary School Principals' Perceptions of the Barriers that Interfere with the Delivery of Educational Services for Foster Children: The Lost At-Risk Children
}

\author{
Janie C. DeVaul
}

West Virginia University

Follow this and additional works at: https://researchrepository.wvu.edu/etd

\section{Recommended Citation}

DeVaul, Janie C., "West Virginia Title I Elementary School Principals' Perceptions of the Barriers that Interfere with the Delivery of Educational Services for Foster Children: The Lost At-Risk Children" (2014). Graduate Theses, Dissertations, and Problem Reports. 501.

https://researchrepository.wvu.edu/etd/501

This Dissertation is protected by copyright and/or related rights. It has been brought to you by the The Research Repository @ WVU with permission from the rights-holder(s). You are free to use this Dissertation in any way that is permitted by the copyright and related rights legislation that applies to your use. For other uses you must obtain permission from the rights-holder(s) directly, unless additional rights are indicated by a Creative Commons license in the record and/ or on the work itself. This Dissertation has been accepted for inclusion in WVU Graduate Theses, Dissertations, and Problem Reports collection by an authorized administrator of The Research Repository @ WVU.

For more information, please contact researchrepository@mail.wvu.edu. 
West Virginia Title I Elementary School Principals' Perceptions of the Barriers that Interfere with the Delivery of Educational Services for Foster Children:

The Lost At-Risk Children

\author{
Janie C. DeVaul
}

Dissertation submitted to the College of Education and Human Services at

West Virginia University

in partial fulfillment of the requirements for the degree of

Doctor of Education

In

Educational Leadership Studies

\author{
Helen M. Hazi, Ph.D., Chair \\ Charline BarnesRowland, Ed.D. \\ Marsha Carr-Lambert, Ed.D. \\ Neal Shambaugh, Ph.D. \\ Richard Walls, Ph.D. \\ Department of Educational Leadership Studies
}

Morgantown, West Virginia

May 29, 2014

Key Words: Foster Children, At-Risk, Caring Leadership 


\begin{abstract}
West Virginia Title I Elementary School Principals' Perceptions of the Barriers that Interfere with the Delivery of Educational Services for Foster Children:

The Lost At-Risk Children

Janie C. DeVaul
\end{abstract}

Foster children are now considered the most at-risk children in American society. Concern for meeting foster children's educational needs falls with the social services domain, however, it is the school system that is responsible for ensuring that all children receive an appropriate education. The schools have programs and policies in place to help the subgroup of identified at-risk students, but foster children are not part of that subgroup. Schools may be overlooking the needs of the foster child because they do not know them as students with special needs. These special needs are not all academics, but they impact the academic process.

Research shows that these children perform poorly in reading, math, and vocabulary, they fail or repeat grades, they struggle to perform at grade level, and many need special education services.

While there has been some research done involving teachers' understanding and perceptions of working with students in foster care, very little has been done with school principals. School principals are held accountable for the academic success of all students. It is challenging for them to meet the needs of foster children when they don't have an understanding of how to do so.

The purpose of this study is to examine the West Virginia Title I elementary school principals' perceptions of the barriers that interfere with the delivery of educational services for foster children.

The findings from this study identify what WV Title elementary school principals perceive to be barriers in educating foster children. School principals can better meet the needs of foster children if they are educated and trained in how to work with this student population. It also provides recommendations to address the barriers identified in order to help foster children succeed academically. 


\section{Acknowledgements}

The last chapter has been written, but just for this story. A new beginning for me starts now. I have had lots of new beginnings in my life and each one has changed me- formed me into the person I am today. I am looking forward to this new beginning, just like I always have because I know I will always become someone different—someone better. But I can't move on without saying thank you to people who have crossed my path in life and made a difference.

I want to express my sincere appreciation to Dr. Helen Hazi, my academic advisor and my chair. We have travelled many miles together academically, and I could not have gotten to where I am today without her expertise, dedication, patience, and especially her belief in me. I want to thank my other committee members, Dr. Charline BarnesRowland, Dr. Marsha CarrLambert, and Dr. Neal Shambaugh. Your contributions were valuable to my success. I want to thank Dr. Walls, who spent hours and hours with me going over numbers and statistics. He was very patient with me. I want to thank Keith Burdette, a fellow colleague who gave me guidance and support. He also directed me to Larry White. I would like say thank you to Larry White, who stepped in to help me wrap my mind around SPSS!

I am blessed with a wonderful family who has been very supportive and encouraging when I needed it most. I want to thank my husband, Bob, who has always believed in me and pushed me to be all that I could be. I want to say a special thank you to my five wonderful children and their spouses, Kristin, JD \& Tiffany, Bobby \& Kristin, Mary and Daniel. I want them to know I am so proud of all of them and what they have accomplished in their short years on this earth. I want to give a special dedication to my first grandchild born on Christmas day 2013. Kingston Lee DeVaul holds a special place in my heart. What the future holds for him is yet to be seen! 
I want to thank God for all of the blessings He has given to me. None of this would be possible without Him. He has always been there for me, even when I didn't have the courage or the strength to call on Him.

It's a new hour, a new beginning and I am ready to embrace it. 


\section{Table of Contents}

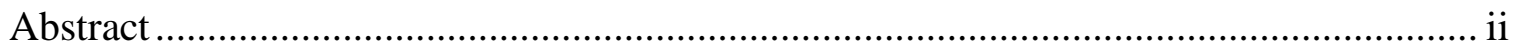

Acknowledgements ................................................................................................ ii

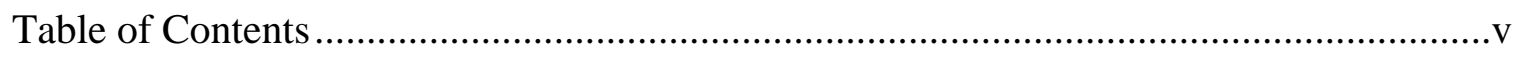

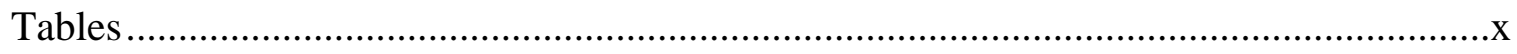

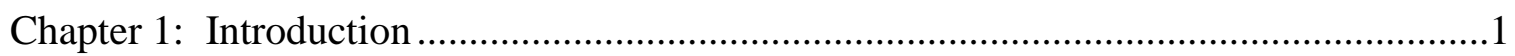

Introduction to the Study ……………………………..........................................

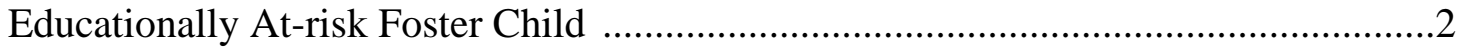

Justification for Research.......................................................................................

Purpose of Study \& Research Questions ..................................................................

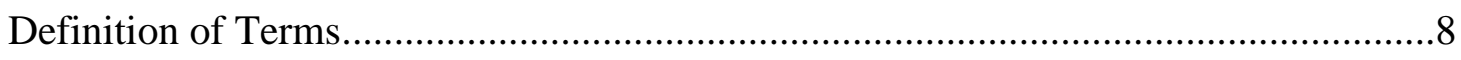

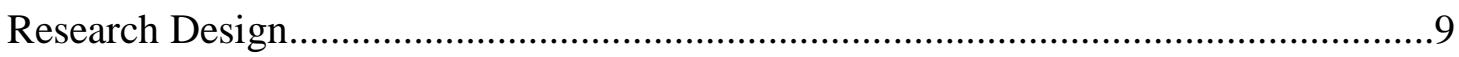

Limitations and Assumptions .............................................................................

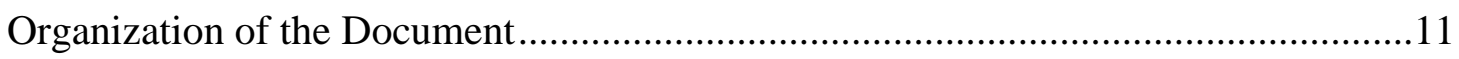

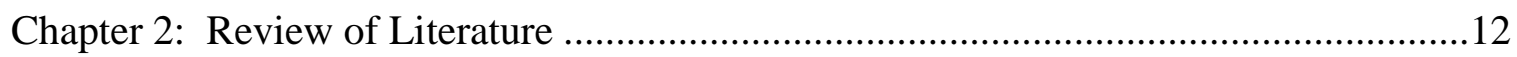

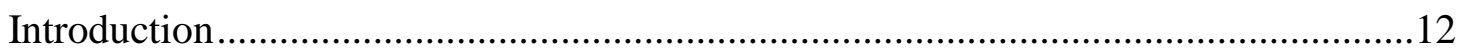

Federal and West Virginia Law ...........................................................................15

Barriers in Educating Foster Children .....................................................................17

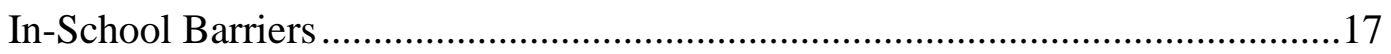

School Personnel..................................................................................18

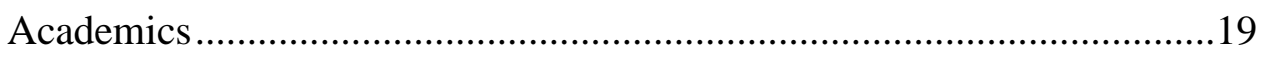

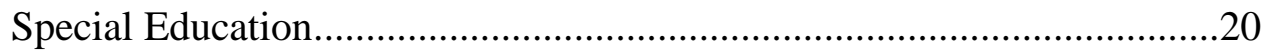

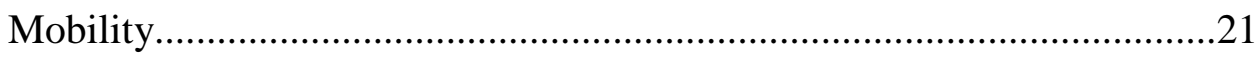

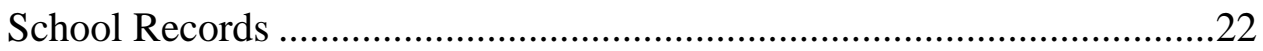




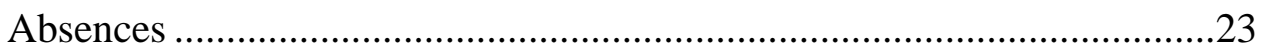

Behavior, Suspensions, \& Expulsions ......................................................23

Outside School Barriers .......................................................................................25

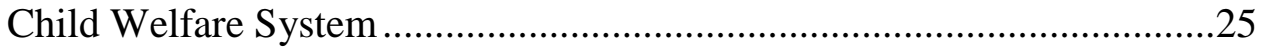

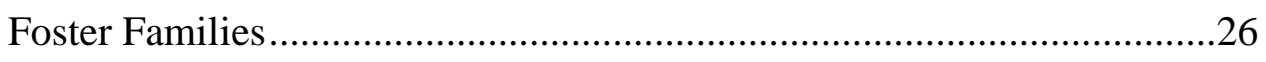

Absences of Advocates ..........................................................................27

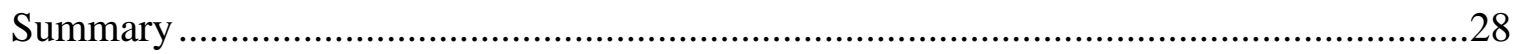

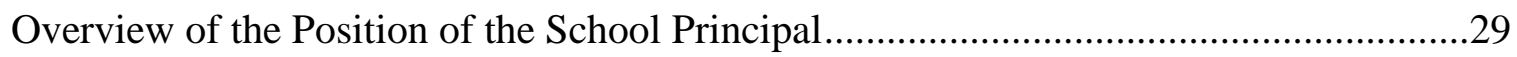

The Changing Roles of Principals ............................................................................29

Searching for the Roots of Care in Leadership ................................................................

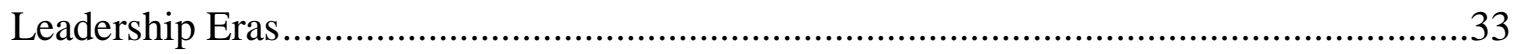

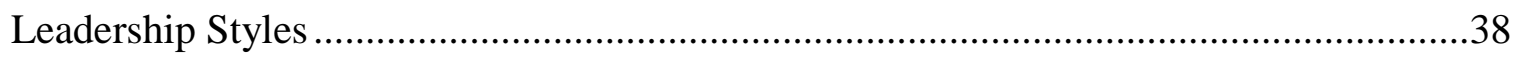

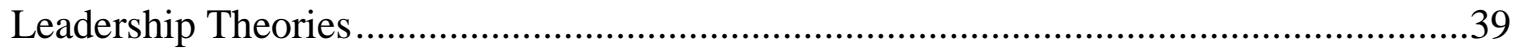

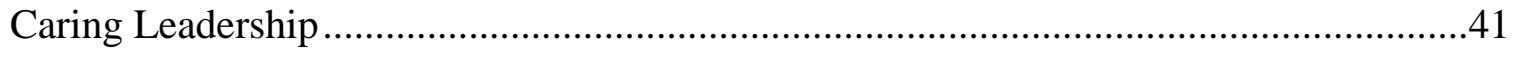

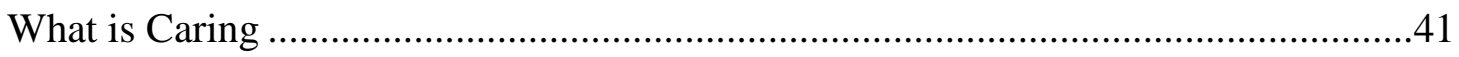

Caring Leadership ..............................................................................................42

Developing Relationships Through Caring Leadership................................................44

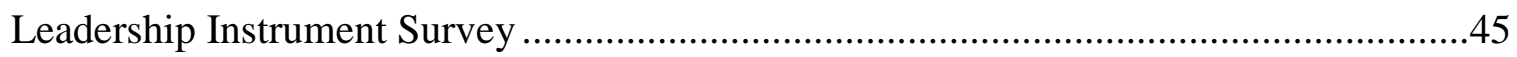

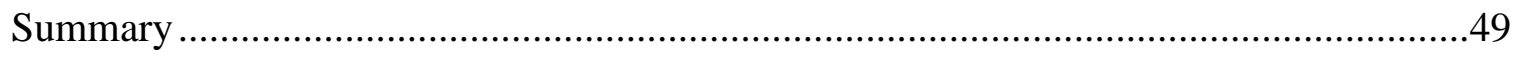

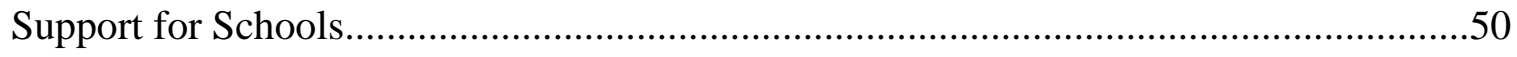

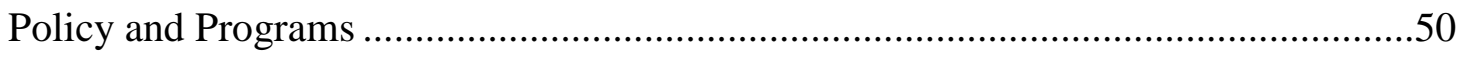

Collaboration Between Agencies..........................................................................

Specialized Training for School Personnel...............................................................52 


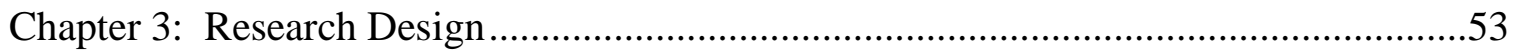

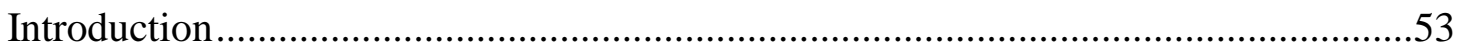

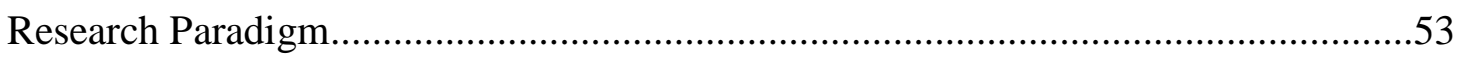

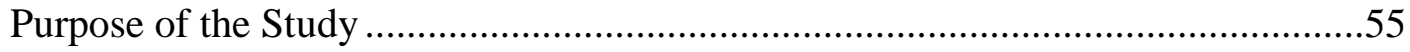

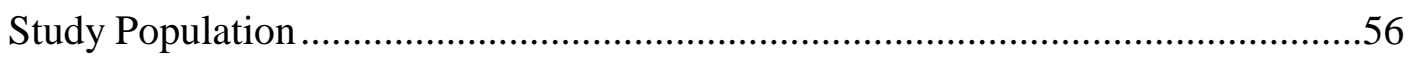

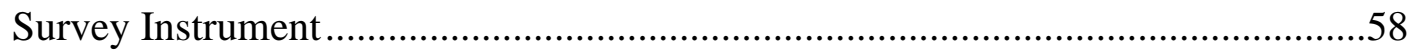

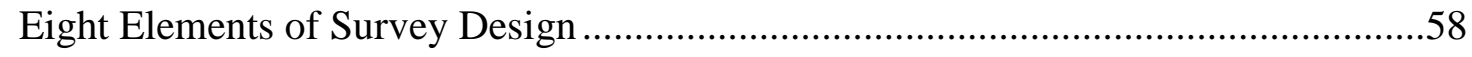

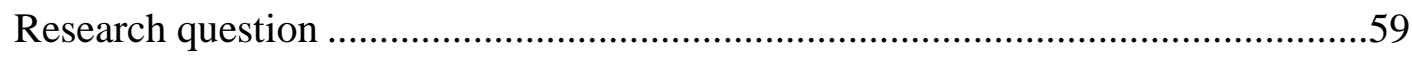

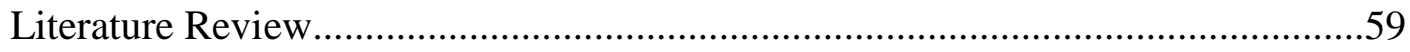

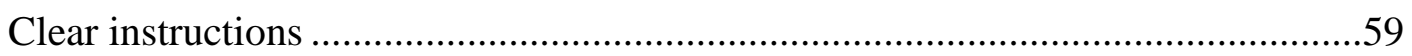

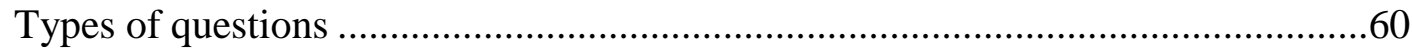

General principles for writing questions ...........................................................6

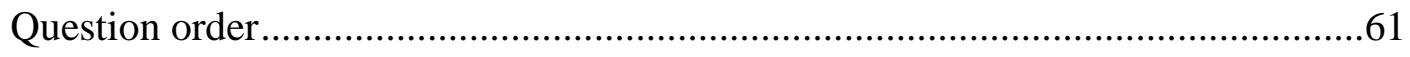

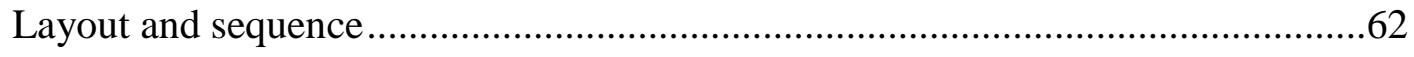

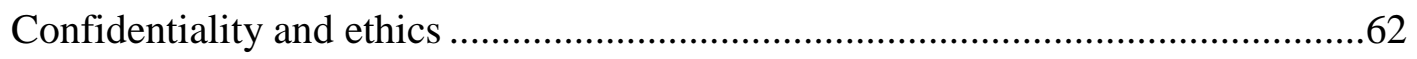

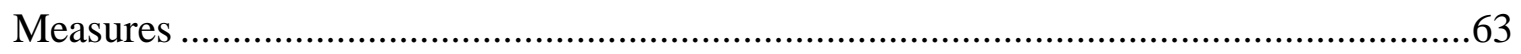

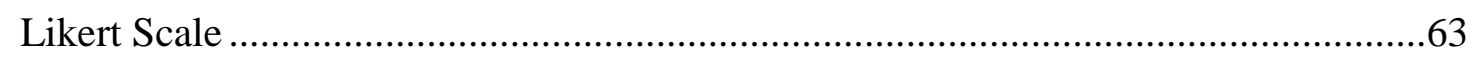

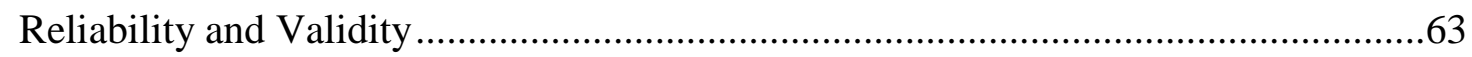

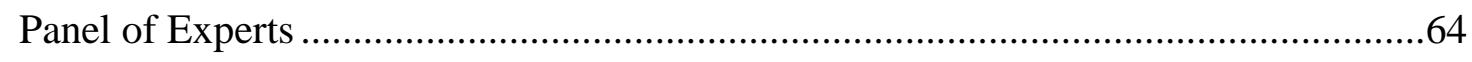

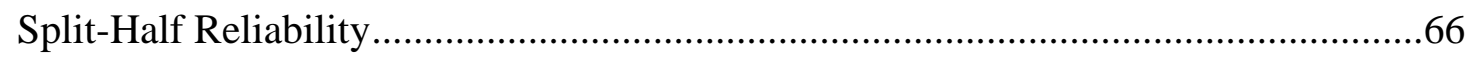

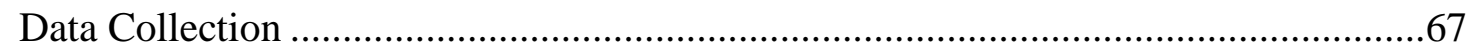

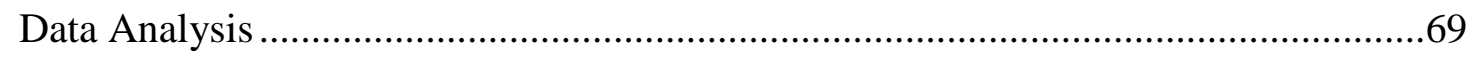

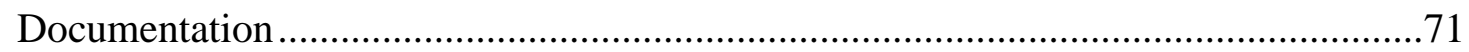


Structured Interview..........................................................................................

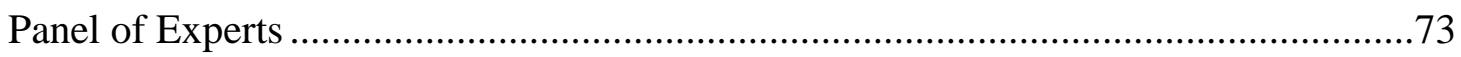

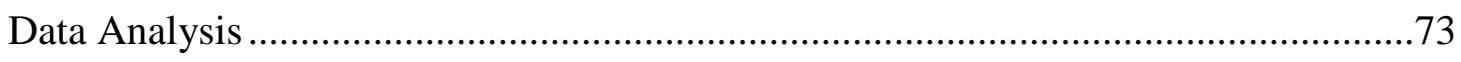

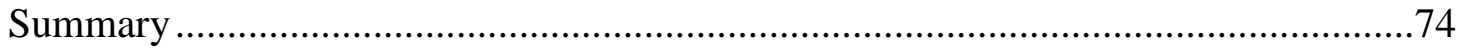

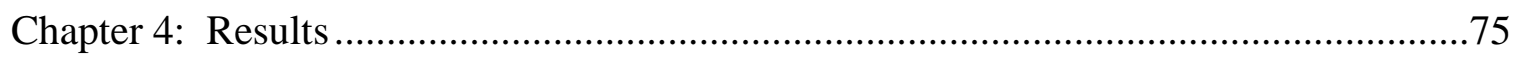

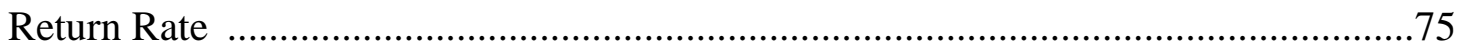

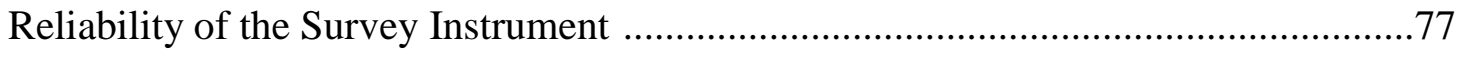

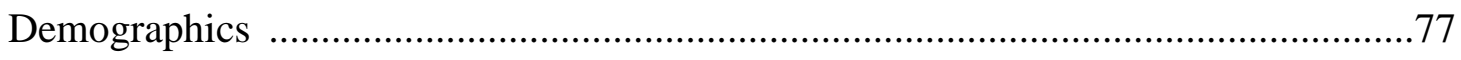

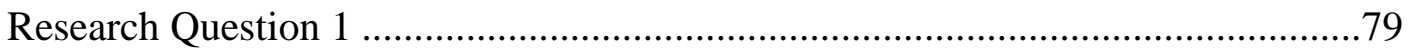

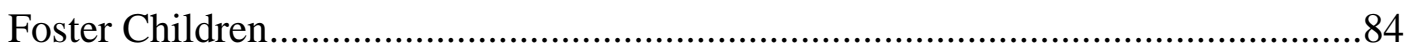

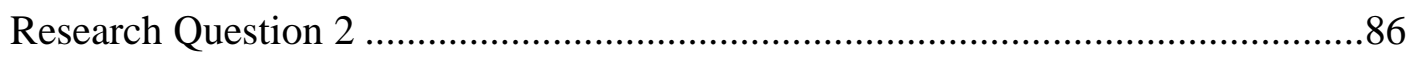

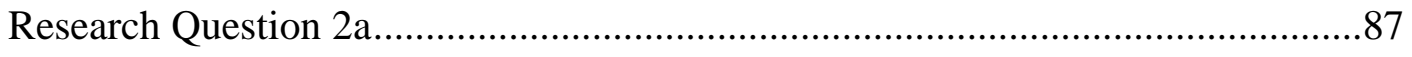

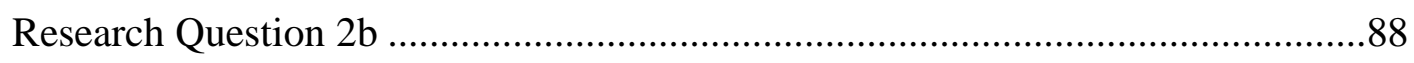

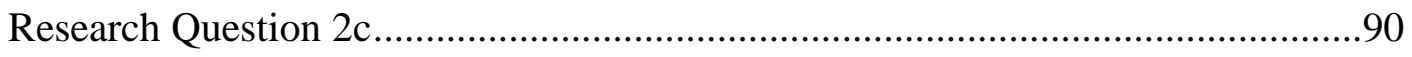

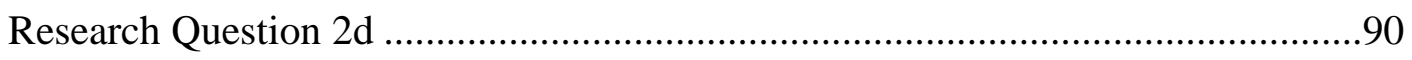

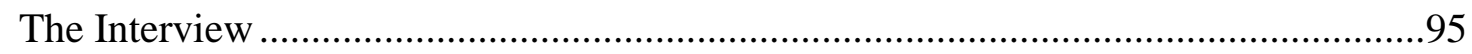

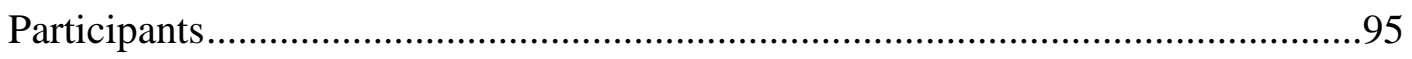

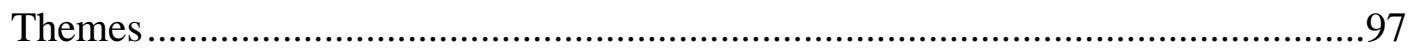

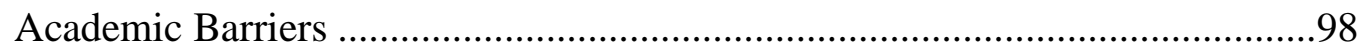

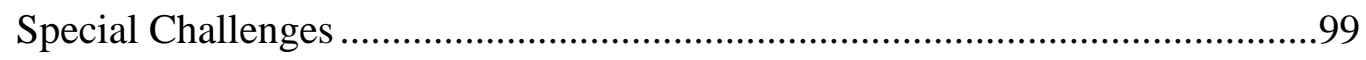

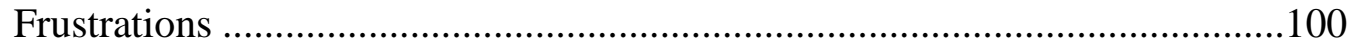

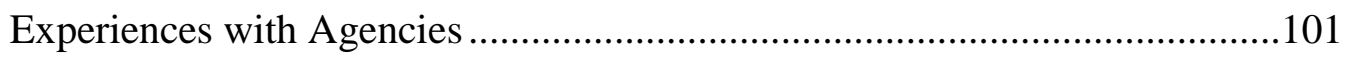

Strategies or Interventions When Working with Foster Children ....................102

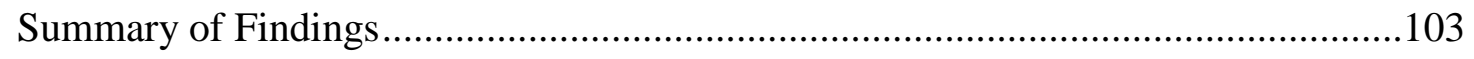




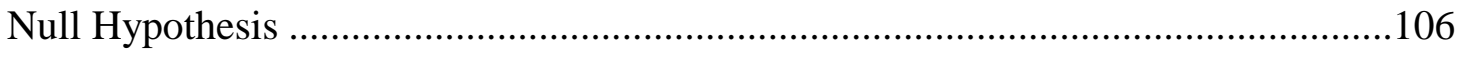

Chapter 5: Conclusions, Discussions, \& Recommendations ..............................................107

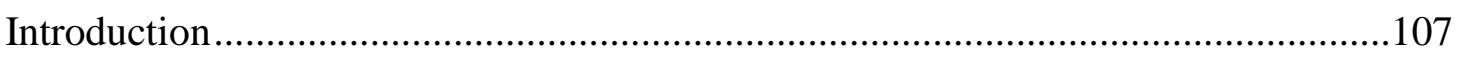

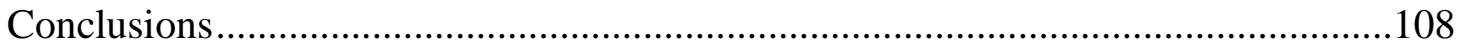

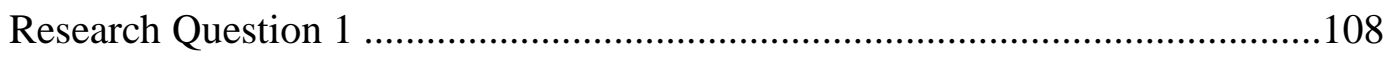

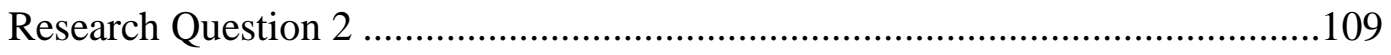

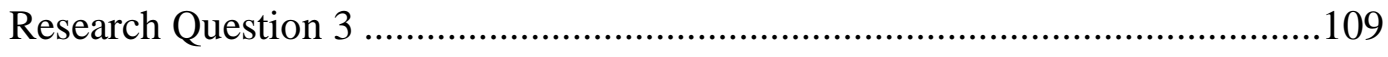

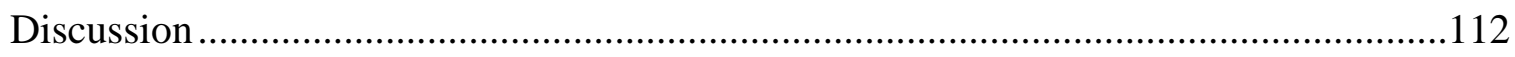

The Non-Participator …………………………………....................................112

Foster Children Do Not Function Well in School at any age .....................................112

There is a Lack of Coordination Between Child Welfare \& the School System........113

Number of Foster Children Reported ..............................................................113

Survey Respondents Identified Barriers that Fell in the Category of In-School

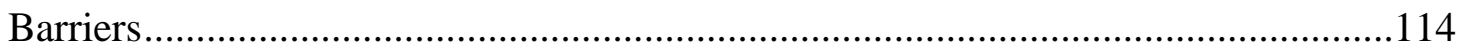

Survey Respondents Indicated the Needs of Foster Children are the Same as

Low SES

Principal Having a Caring Leadership Role …………….........................................115

Recommendations for Practice ………………………….....................................115

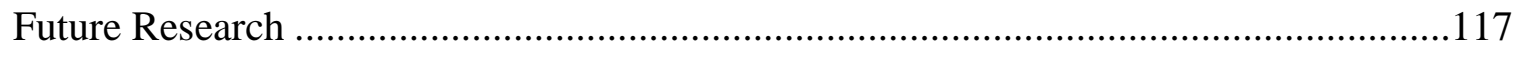

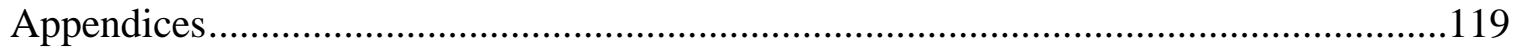

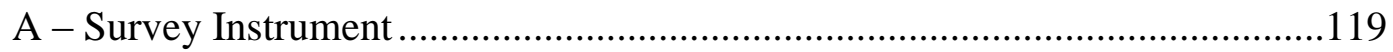

B - Survey Matrix Displaying the Relationship Between the Literature and the Survey

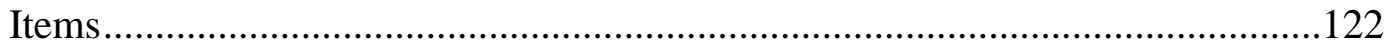


$\mathrm{C}$ - Introduction and Closing for Interview ……………..............................126

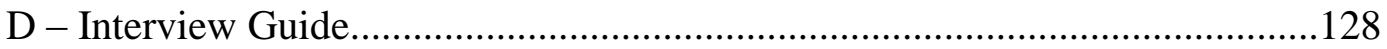

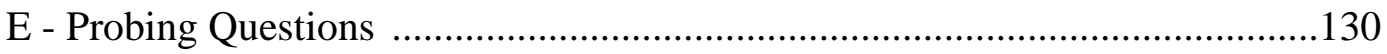

F - Matrix Displaying the Relationship Between the Literature and the Interview

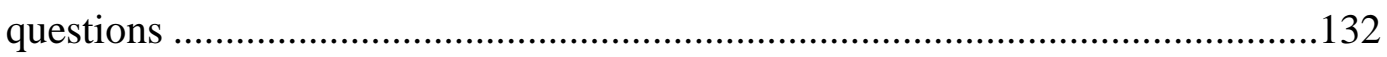

$\mathrm{G}$ - Concept Map Displaying the In-school Barriers.........................................135

H- Concept Map Displaying the Out-school Barriers ..........................................136

I- Directions to Panel of Experts Reviewing the Proposed Survey Instrument ..137

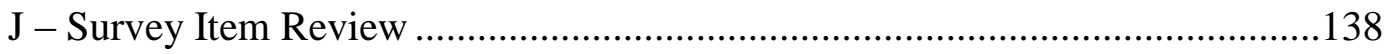

K- Superintendent Notification Letter............................................................143

L- Letter of Invitation to Participate in Survey .....................................................145

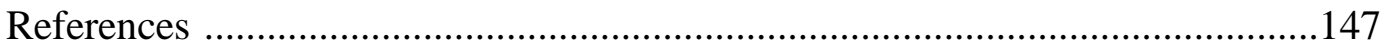


List of Tables

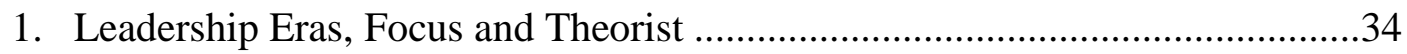

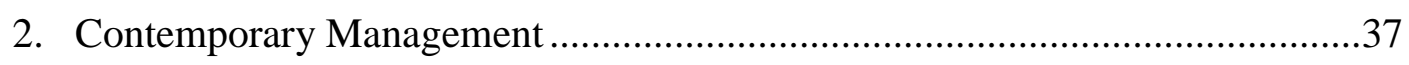

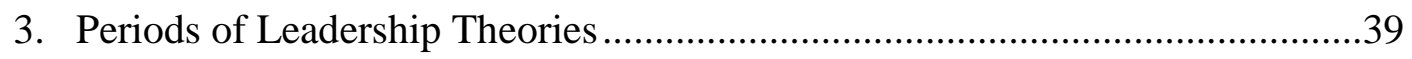

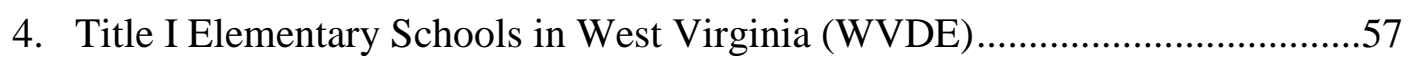

5. Comparison of Demographic Information of Early Respondents and Late

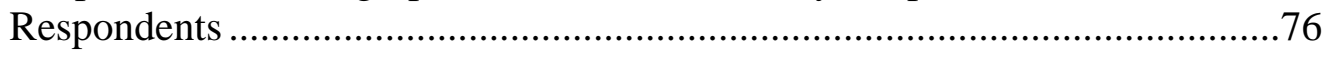

6. Number of Years Respondents Have Served as Administrators and Served at

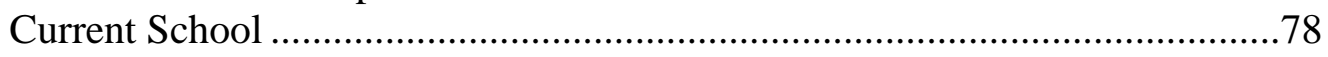

7. Number and Percent of Respondents and Gender of Respondents from the

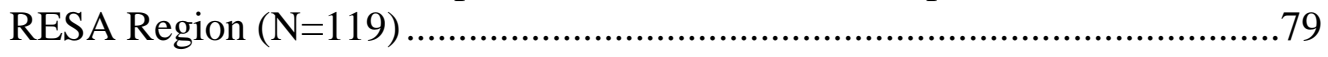

8. Mean Ratings and Standard Deviations (SD) for Each of the 24 Barriers ........81

9. Number of Foster Children Enrolled in Schools in Each of the Eight RESA

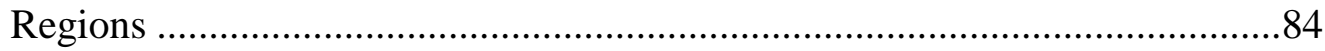

10. How Principals Find Out That Students in Their School are Part of the Foster

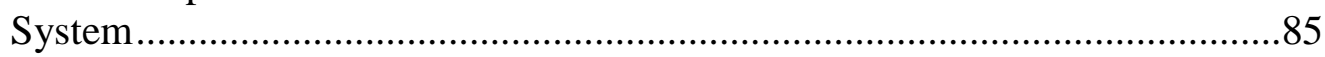

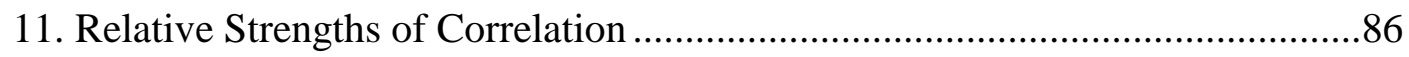

12. Correlation of Principals' Years of Experience as a Principal and Their Perceptions of the 24 Barriers

13. Correlations of Principals' Years as Principal at that School and Their Perceptions of the 24 Barriers.

14. Correlations of Principals' Gender and Their Perceptions of the 24

Barriers

15. Correlations of Principals' RESA Region and Their Perceptions of the 24 Barriers.

16. Interventions to Address the Identified Barriers and Themes 116 


\section{Chapter 1}

\section{Introduction}

If past trends continue in the educational domain for children placed in foster care, they could, according to Chisholm (2010) remain one of the most "educationally vulnerable populations in America” (p. 1). According to Children's Rights (2013) “on any given day, there are approximately 400,000 children in out-of-home care" (para. 1). Foster care is when a child is cared for by a person or people who are not their family members. These are children who have been removed from their homes because of abuse, neglect or reasons that interfere with the biological families to provide adequate care (Child Trends, 2011). "The removal of a child from biological parents requires a substantiation of maltreatment, not just an exposure to it" (Bruskas, 2008, p. 70). Foster children historically come from poor families; from troubled families who deal with problems, such as poverty, homelessness, substance abuse, and lack of family supports (Barbell \& Freundlich, 2001; Zetlin, Weinberg, \& Kimm, 2005). While foster care is supposed to be a temporary condition, many children remain in the system permanently. Most of these children end up in multiple foster homes, which "heightens their risk of academic challenges" (Child Trends, 2011, para. 2).

Social expectations and "standards for acceptable family functioning" (Barbell \& Feundlich, 2001, p. v.) has an impact on the public's awareness and reaction to child abuse (Barbell \& Freundlich, 2001). With this awareness comes an obligation to report the abuse. As families are confronted with poverty, homelessness, substance abuse, and declining informal and extended family supports child abuse and neglect increase and the reports to Child Welfare increase. 
During the 1960s the number of reports of child abuse and neglect grew tremendously. This time period saw a steady increase in the number of children being placed in foster care homes (Barbell \& Freundlich, 2001). When the Adoption Assistance and Child Welfare Act of 1980 came into existence, the number of foster children dropped. But during the late 1980s the numbers once again began to increase at a quicker pace than ever before. Berrick (1998) noted that an increase in the number of children being placed in foster care is due, in large part, "because of substance abuse by parents" (para. 4). According to Barbell \& Freundlich (2001) this trend of growth in foster care continues, with children having characteristics that make them difficult to place and sometimes to treat. Information from the Data Snapshop (2011) indicated that there were 424,000 children in foster care in the United States.

Foster care has evolved over the years and as it has, a very complex child welfare system also has developed. Within this system there are challenges, such as, growing caseloads that have complex needs, lack of appropriate resources for children, high staff turnover, and difficulty in recruiting foster parents (Chipungu \& Bent-Goodley, 2004).

\section{Educationally At-risk Foster Children}

While research identifies foster children as one of the most at-risk, educationally vulnerable populations in school (Finkelstein, Wamsley, \& Miranda, 2002; Kools \& Kennedy, 2003; Lips, 2007; Stone, D’Andrade, \& Austin, 2007; Zetlin, 2006; Zetlin \& Weinberg, 2004; Zetlin, Weinberg, \& Kimm, 2003; Zetlin, Weinberg, \& Shea, 2006), “no one acknowledges primary responsibility for the educational progress of foster children" (Finkelstein, Wamsley, \& Miranda, 2002, p. 3).

Gustavsson \& MacEachron (2010, p. 276) note that "a consistent pattern in empirical literature since the 1990s is that the educational needs of these children are poorly addressed and 
they remain at elevated risk of negative educational outcomes". According to Altshuler (1997), foster children struggle to succeed in school and there is a large percentage that will experience school failure. Research tells us that $30 \%$ perform below level, $50 \%$ are held back in school, $46 \%$ do not complete high school, and less than $3 \%$ go on to four year colleges (Zetlin, 2006). School is forgotten when the goal is to protect the child from abuse and neglect or trying to find them a new home (Reaching Every Child, 2005).

The signing of No Child Left Behind Act (USDE, 2002) sparked the beginning of an “educational policy era marked by accountability and an emphasis on increasing student achievement" (Brooks \& Miles, 2006, p. 26). According to Thurlow (2000) many states have adopted school reforms that are designed to make school learning environments more rigorous. While these efforts are affecting many dimensions of school life, there are concerns that students identified as at-risk are being left behind (DiPaola \& Walther-Thomas, 2003). NCLB identifies many categories of at-risk students, such as, low-income students, students with disabilities, homeless students, and students of racial and ethnic subgroups, in order to provide supplemental educational services for them through federal programs, such as Title I.

Title I (USDE, Title I, Part A, 2014) is a federal program that provides funds to schools that have a high number of students that are identified as disadvantaged. The criteria that is used for this is the poverty level of parents, which is indicated by the child being eligible for free and reduced priced lunches. An article in The Charleston Gazette (2013) notes that the federal poverty threshold is $\$ 23,550$ for a family of four. Data show that in 2012 nearly one in 10 West Virginia families were living in poverty. School districts rank schools in order of the poverty level, and the schools with the highest poverty level receive the federal funds first. The funding is used for greater instructional intensity and more opportunities for students to learn. 
The West Virginia Department of Education uses the guidelines set forth in the McKinney-Vento Homeless Assistance Act. The McKinney-Vento Act (USDE Homeless Education, 2001) is instrumental in identifying the homeless student population. The McKinneyVento Act defines "homeless" as follows:

- Individuals who lack a fixed, regular, and adequate nighttime residence;

- Children and youth who are sharing the housing of other persons due to loss of housing, economic hardship, or similar reason; are living in motels, hotels, trailer parks, or camping grounds due to the lack of alternative adequate accommodations; are living in emergency or transitional shelters, are abandoned in hospitals, or are awaiting foster care place;

- Children and youths who have a primary nighttime residence that is a public or private place not designed for or ordinarily used as a regular sleeping accommodation for human beings;

- Children and youths who are living in cars, parks, public spaces, abandoned buildings, substandard housing, bus or train stations, or similar settings. (p. 2, Part C)

The McKinney-Vento Act awards grants to the 50 states, based on each state's share of Title I funds. The West Virginia Department of Education uses the grants to support an Office for Coordination of Education of Homeless Children and Youths (WVDE, 2014). All school districts in West Virginia are to have liaisons that help identify homeless youth and help them receive the services and supports needed to help them enroll in school.

In contrast, foster children are more difficult to identify due to the fact that there is a lack of a common identifier. The at-risk foster children are not recognized as a category under the No 
Child Left Behind Act (USDE, 2002). Principals find out that students in their schools are part of foster care in the following ways: foster parent/legal guardian, Child Welfare, family member/relative/family friend, the student him/herself, counselor/teacher/colleague, appearance of cumulative records/documentation, or law enforcement. However, not all foster children are identified and they become lost as they are passing through the school system.

According to Zetlin, et al. (2003) children placed in foster care are at a tremendous risk educationally. Joftus (2007) notes that even though the foster child is considered an at-risk, vulnerable population, they are not given opportunities that other at-risk groups receive. Stone (2007) indicates that the educational progress for foster children is poor due to overlooking their special needs. Gustavsson \& MacEachron, (2010) note that youth in foster care are at risk for negative educational outcomes.

According to Palladino (2006) school principals are unaware of the presence of foster children in their schools and their needs as learners. Research indicates that the school principal does not recognize the foster child because there is a lack of awareness, expectations, educational strategies, and exposure to fully understand the foster child's plight (Reaching Every Child, 2005). It is challenging for school principals to meet the needs of foster children when, according to Weinberg, Zetlin, \& Shea (2006), they have little or no understanding of the foster child's plight in the foster care system. Zetlin, Weinberg, \& Kimm (2003) have noted that when schools are not adequately involved and informed about a child's foster care situation, the curricula, pacing and teaching methods can't be adjusted to meet the needs of the child. Due to confidentiality mandates this risk expands when both child welfare agencies and school districts feel the need to limit what is discussed in reference to the foster child. Thus, it is difficult to 
address the educational needs of the at-risk foster child. The foster child's educational and emotional needs get lost in the shuffle.

Much attention has been given to understanding the characteristics of children in foster care, but not much has been done in examining the academic barriers facing these children (Ferguson, 1999). Because there is limited research in this area, there are no state or district guidelines in place to guide the school principal in addressing the educational needs of children in foster care.

\section{Justification for Research}

This study examines West Virginia Title I elementary school principals’ perceptions of barriers that interfere with the delivery of educational services to foster children in public schools. School principals can better meet the needs of the foster child if they have an understanding of the barriers that impede the academic success of the child (Cormier, 1994). Principals will have the opportunity to indicate what they perceive to be barriers in their school and barriers out-side of the school environment that interferes with the ability to deliver educational services to foster children.

This research is important because greater insights will be available to determine what strategies, interventions, or programs are needed in order for school principals to provide necessary supports for foster children to be academically successful in the public school setting. This research is also important to determine how school principals can be supported when working with a student population that is part of the complex Child Welfare System.

In West Virginia the number of children in foster care increased by $25 \%$ or more between

the years of 2000 and 2009 (Child Trends, 2011). According to the West Virginia Department of Health \& Human Resources (2005): 
National trends reflect events that are occurring in West Virginia. West Virginia has experienced rising incidents of child abuse and neglect, growing numbers of adjudicated delinquents, and increases in the number of children who are mentally or physically disabled. These factors have caused the number of children removed from their homes and placed into foster care to increase sharply (para. 11).

An article in the West Virginia Gazette (2005), noted that only one-half of the 3000 foster children in West Virginia will stay in the same school for the school year. It is also noted that a “perpetual air of distrust, lack of communication and understanding of all parties" (Eyre, 2005, p. 1C) exists in the schooling of foster children in West Virginia. Priscilla Haden, a state school board member is quoted as saying, "It seems to me these are lost children in West Virginia" (Eyre, 2005, p. 1C).

\section{Purpose of Study \& Research Question}

The purpose of this study is to examine West Virginia Title I elementary school principals' perceptions of barriers that interfere with the delivery of educational services for foster children in public schools.

A quantitative design was used with questions number one and two because of its ability to interpret data and provide a description or picture of a situation. If participants agree to be interviewed, a qualitative design was used with the third question.

The study was guided by the following research questions:

1. What barriers do principals in West Virginia Title I elementary schools perceive exist for foster children? 
2. Is there a relationship between the principals' perception of the barriers and (2a) years of experience as a principal; (2b) years as principal at that school; (2c) gender; and (2d) region?

3. What experiences have principals in West Virginia Title I elementary schools had with foster children?

\section{Definition of Terms}

At-risk: A probability that a student will fail academically or drop out of school (Cormier, 1994).

Barrier: Something that prevents progress or makes it difficult for someone to achieve something (MacMillian Dictionary, 2013).

Child Welfare System: An agency or public system whose mission is to protect children who have been abused or neglected and reduce the risk of endangerment (Zetlin, 2006).

Foster Care: Planned services for a child which includes placement of child in the temporary care of a family other than their own biological family as a result of abuse and/or neglect within the family (Emerson \& Lovitt, 2003).

Foster Child: Abused or neglected children, who must be removed from their biological parents' custody and placed in foster care (Emerson \& Lovitt, 2003).

Homeless Population: Individual who doesn't have permanent housing and may live on the streets, stays in a shelter, or may live in an abandoned building or vehicle. Individuals who are forced to leave their homes and stay with friends or extended family members are also considered to be part of the homeless population.

Principal: A person holding appropriate and valid administrative certification who, under the supervision of the superintendent and in accordance with the rules and regulations of 
the county board of education, assumes administrative and instructional supervisory responsibility for the planning, management, operation and evaluation of the total educational program of the school or schools to which he or she is assigned (WV Code, 2012).

Title I: Title I provides federal funding to schools that have at least $40 \%$ of their children in the school attendance area coming from homes that are low-income homes. The proportion of low income families is measured by the percent of students receiving free and reduced-priced lunches.

\section{Research Design}

This study is quantitative in nature and addresses the methods used to determine West Virginia Title I elementary school principals' perceptions of barriers, if any, that interfere with the delivery of educational services for foster children in their school.

The researcher feels the most suitable research method is a survey. A survey developed by the researcher based on the literature review is the instrument that was used to gather the data for this study. There are eight categories of factors (school personnel, academics, records, special education, behavior, social, Child Welfare System, and foster families) on the survey that gathered the perceptions of Title I elementary school principals. The researcher gathered data through a formal, written set of closed-ended questions, in electronic form. Using a Likert scale with end points of "strongly disagree" to "strongly agree", the respondents selected the categories that best describe their reaction to whatever is being rated. Because there is no previous instrument, validity for this instrument was determined through a panel of experts.

If participants agreed on the survey to be interviewed the researcher used a qualitative phenomenology design for the third question. Qualitative research is about finding out not just what people think, but why they think it. Data for the qualitative design was gathered using an 
interview format that asked open-ended questions to gain in-depth responses about the school principal's experiences, opinions, perceptions, feelings and knowledge of foster children (Creswell, 2004). Through the collection of data in a second phase, the researcher hoped to gather a more in-depth understanding of the experiences school principals' had with foster children. It is a method of discovering how a person interprets something through their own experiences.

The data from the qualitative design were analyzed by coding or categorizing the information. To bring meaning to the data, the researcher identified themes, ideas and patterns from the interviews (Patton, 1990).

\section{Limitations and Assumptions}

One limitation of the study is that it will be restricted to West Virginia Elementary Schools that have Title I services in the building. The researcher identified these schools because they service a low SES population of students, and research indicates that many foster children are placed in homes that are identified as low SES environments.

Other limitations of the research include:

- The survey may not yield sufficient participation

- The interview process is heavily dependent on the skills of the researcher

- School administrators may not feel comfortable responding to such a sensitive topic

- School administrators may not have enough background in the area to respond to the topic

- Not a guarantee of honest responses

\section{Organization of the Document}


This document is organized into five chapters. Chapter One provides an overview of the study with an introduction to the topic, statement of the problem, study purpose, research questions, limitations and definitions of terms.

Chapter Two is review of the literature looking at barriers in educating foster children, position of the school principal, and caring leadership.

Chapter Three presents the research design to be used in this study. The chapter includes the research design, purpose of the study, the study population and the survey instrument. It also gives an overview of reliability and validity, discusses the panel of experts, pilot study, and how the data was collected and analyzed.

Chapter Four is the data analysis and reports the findings from the data collected.

Chapter Five has the conclusions from the study, any discussions and recommendations from the study. 


\section{Chapter Two \\ Review of the Literature}

\section{Introduction}

In this research, the definition of at-risk refers to a student who will most likely fail academically or drop out of school (Cormier, 1994). According to research foster children are one of the most academically at-risk populations in the education system (Ellerman, 2007; Lips, 2007; Zetlin, 2006; Zetlin, Weinberg \& Kimm, 2003; Zetlin, Weinberg \& Shea, 2006). A study done by Vera Institute of Justice (1999-2002), notes that "foster children face unique challenges and obstacles beyond those faced by even their most economically disadvantaged non-foster peers" (p. 1).

Beginning in the 1960s policy makers identified the failure of schools to teach students who were educationally disadvantaged, or considered to be "at-risk." Educators and the general public also began to recognize and express concern over children who were identified as "atrisk." While definitions of at-risk children vary among educators, Rush \& Vitale (1994) indicated eight significant factors that could place a child in the category of at-risk: (1) poverty, (2) behavior, (3) ethnicity (4) language development, (5) disability, (6) coping skills, (7) attendance, and (8) family configurations (e.g., living in a single parent home, limited education of parents). A child is also identified as at-risk if they are considered to be homeless. However, there is one unidentified lost subgroup not recognized, foster children.

Frerer, Sosenko, Pellegrin, Zakharenkov, Horowitz and Patton (2011) indicate that "students in foster care not only fall behind the general student population; they fall behind other at-risk student populations" (p. 3). However, foster children have other special needs that are not always academic, but impact academic progress. According to Keating (2000) children in foster 
care come to school with "impaired learning readiness, with serious issues of grief and loss, and usually with less than age-and grade-appropriate academic and social skills" (p. 17).

Research and studies done in this area indicate that the educational needs of foster children are not being met (Zetlin, Weinberg, \& Kimm, 2003). According to national statistics there are approximately 500,000 children in foster care (U.S. Department of Health \& Human Services, 2008). There are approximately $70 \%$ of children in foster care who are school age (Emerson \& Lovitt, 2003), and according to Lips (2007), research shows that academic problems begin early for foster children. Black (2006) stresses the urgency of serious school problems faced by foster children. When compared with their peers who have not been in foster care, foster children are more likely to be retained a grade level and do not stay in the same school for an extended amount of time (Zetlin, Weinberg, \& Kimm, 2003). Foster children also tend to be placed in special education classes more often than other students (Washington State Institute for Public Policy, 2008).

There are an estimated 420,000 children who are entering schools where the educational professionals lack knowledge of how to meet the challenges of the foster child's many needs (Cormier, 1994; Ellermann, 2007; Emerson \& Lovitt, 2003; Finkelstein, et.al., 2002; Schwartz, 1999). There has been much research conducted that focuses on the characteristics of children in foster care, but very limited research gathered on foster children in school (Ferguson, 1999). Foster children are victims of educational neglect prior to and during their foster care experiences and school principals seldom understand the plight of foster children. This brings to surface a growing concern among educators and child welfare experts that many foster children will get left behind academically. 
According to Fletcher-Campbell (1997) the need to identify a successful model for addressing the educational needs of foster children has not yet been explored. One of the challenges facing a school principal is to create and nurture an environment that will support learning for foster children. School principals have a difficult time identifying students who are part of the welfare system for many reasons, including "organizational bureaucracy and differing cultures among systems" and "ineffective communication between agencies, or confusion among agencies' roles" (National Center for Mental Health Promotion and Youth Violence Prevention, 2010, para. 4). Schools have a difficult time making informed decisions regarding classroom and academic placements, safety issues and disciplinary boundaries for foster children due to the lack of information shared about the child (Vacca, 2008).

School principals are responsible for establishing a positive and productive learning environment for all students, with a focus on at-risk students, many of whom are in foster care. In order for them to positively influence the educational outcome of foster children, they need more guidance in how to overcome the barriers of transforming schools into institutions that focus on helping foster children succeed (Kellam, 2000). Gaining an understanding of the barriers that foster children face on a daily basis could help school principals improve the educational opportunities for children who are in foster care (Lips, 2007).

This chapter is divided into five major sections. Section one includes a brief review of Federal and West Virginia policies that impact foster children. Section two, Barriers to Educating Foster Children, has two parts: (a) barriers within the school environment that interfere with the academic success of foster children, and (b) barriers outside the school that interfere with the academic success of foster children. Section three will look at the role of the school principal. Section four examines searching for roots in caring leadership, including, (a) 
leadership eras, (b) leadership styles, and (c) leadership theories. Section five will include caring and caring leadership, and developing relationships through caring leadership.

Federal and West Virginia Law

Federal laws have had a major impact on foster care for children over the years. Starting in the 1900s laws, such as, Child Abuse Prevention and Treatment Act of 1974, the Adoption Assistance and Child Welfare Act of 1980, Child Abuse, Domestic Violence, Adoption and Family Services Act of 1992, the Adoption and Safe Families Act of 1997, and the Foster Care Independence Act of 1999 addressed concerns about child protection, child welfare and adoption. Congress continued to implement a number of laws that would have an impact on child protection and child welfare services, such as, Keeping Children and Families Safe Act of 2003, the Fair Access Foster Care Act of 2005, and the Safe and Timely Interstate Placement of Foster Children Act of 2006 (Allen \& Bissell, 2004).

Foster care has evolved to where it is focused on keeping the children safe, not educating them. Federal and state laws echo this concept. Research in the 1960 s revealed that foster placement was often permanent instead of temporary; frequent moves caused instability in the lives of children; children from poor families were disproportionately represented in foster care; and there was concern over the negative impact of separation on children from their families. In the early 1960s the Aid to Families with Dependent Children expanded and federal funding for foster care was provided. This allowed for care to children who were not safe with their families (Allen \& Bissell, 2004). According to Herman (2012) "the result was an explosion in out-ofhome family placements. Foster care is now the main form of assistance provided to poor children in the United States who cannot remain in their own homes because of neglect or abuse" (para. 6). 
According to Julianelle (2008) one of the purposes of the McKinney-Vento Homeless Assistance Act was to "increase school stability of youth who are awaiting foster care placement" (p. 2). Even though the law mandates that school districts designate a homeless liaison and ensure that "eligible students are identified, enrolled and receiving the support that they need to succeed in school" (p. 2), the funding for schools nationwide "results in only $6 \%$ of school districts" receiving the financial help.

While the primary responsibility for child welfare is that of the state, and each state has its own framework to address the needs of foster children, it must comply with specific federal requirements. Over the past several decades, federal legislation has shaped the delivery of child welfare services, such as housing, health care, welfare, social security benefits, taxes and foster care reimbursement. None of the acts have significantly addressed or involved the educational inadequacy of the foster child. Educational leaders are in a unique position to identify, prioritize and support practices that address barriers to learning and teaching and to develop and sustain appropriate staff development and trainings to address the academic needs of foster children. These practices can improve learning opportunities for foster children by expanding their educational options (California Child Welfare Co-Investment Partnership, 2011).

West Virginia's Chapter 24 Foster Care Policy provides the legal basis and practices and procedures necessary to provide foster care services. According to the West Virginia Department of Health and Human Resources Bureau for Children and Families (2005): Under §49-2-1 of the West Virginia State Code, the Department of Health and Human Resources is empowered to administer a foster care program for dependent and neglected children. This allows the Department to accept custody of children and place them outside of their families of origin in order to protect and care for them. When 
children are in foster care, the Department assumes part or all of the responsibility for children that ordinarily rests with the parents. (p. 16)

\section{Barriers in Educating Foster Children}

The situation surrounding the education of foster children is a complex one. Stone, D'Andre, \& Austin (2007) assert that child welfare advocates and policy makers alike express concern that the educational needs of children in foster care are not being met by both the welfare system and the educational system. Concerns for meeting the educational needs of foster children falls within the social services domain of child well-being, but it is the school system that is clearly responsible for ensuring that all children receive an appropriate education.

School principals are leaders of instruction and managers of school climate who play a crucial role in empowering their teachers to be effective instructors for all students. They are forced to work within the constraints of the foster care system, while struggling to improve the serious deficiencies associated with foster children. Educating foster children is a multi-faceted problem which makes it necessary to examine policies, practices, and specific barriers inside and outside the school environment.

In-school barriers. Education is important in the life of a foster child. The school experience can affect the quality of the foster child's life day-to-day. School principals need a clear understanding about the effectiveness of our current educational system serving children in foster care (Finkelstein, et al, 2002; Lips, 2007; Stone, et al., 2007; Zetlin, et al., 2003; Zetlin, et al., 2004; Zetlin, 2006; Zetlin, et al., 2006). Stability is essential for educational achievement of foster children. A review of literature has indicates the importance of supporting education for foster children (Altshuler, 1997); however, research has not identified barriers that school principals have experienced when working with foster children in their schools. This study is 
focuses on seven in-school barriers which consist of: (a) school personnel, (b) academics, (c) special education, (d) mobility, (e) school records, (f) absences, and (g) behavior, suspensions \& expulsions.

School personnel. Cormier (1994) indicates that educators have a vast background of experience, but they are not given preparation that adequately prepares them to cope with or to teach children in foster care. Because of a lack of clear understanding of this diverse population, foster children tend to struggle academically (Cormier, 1994). Because of their lack of training and understanding, school principals may unintentionally give foster children the feeling of being an outsider (Vacca, 2004). School personnel may have low expectations because they have misconceptions about foster children (Powers \& Stotland, 2002).

While studies indicate the importance of helping foster children succeed in school, Palladino (2006) notes that teachers indicated that they cannot help foster children in their class if school principals do not give them the information they need about a foster child. School principals cannot convey the information requested when they fail to understand the academic barriers facing at-risk foster children (Avery, 2001).

Some studies have revealed that school personnel lack knowledge of the special needs of foster children. School personnel may not understand that foster children have a history of family chaos and turmoil, emotional and physical neglect, along with physical and sexual abuse (Gustavsson, 1991). They do not realize that foster children suffer, either from physical abuse, grief from separation from family, or the confusion of several moves. One major aspect that is missing from the foster child's life is that sense of belonging. They have been removed from their home and families, have moved from school to school, and have no lasting friendships or relationships (Reynolds, 2011). 
Foster children go into schools and classrooms where principals and teachers may have a preconceived notion that foster children are not smart enough to profit from their efforts. Educators don't bother to take any time with the foster child because they figure they won't be there long enough for them to make any difference (Powers \& Stotland, 2002). School personnel that try to get involved in the foster child's life often lack the full picture of what the child's educational needs are. Unfortunately, the foster parents are mostly concerned about the child's behavior and caseworkers focus on the crisis that has affected the child (Finkelstein, et.al, 2002).

Academics. Research indicates that foster children do not function well in school at any age, and they are academically at-risk for school failure (Avery, 2001; Christian, 2003; Pears, Fisher \& Bronz, 2007). There are multiple risks factors that contribute to the poor educational outcome for foster children (Finkelstein, et.al, 2002; Stone, 2007; Zetlin, 2006). Kindergarten is a key developmental milestone for children. Most foster children begin kindergarten lacking the social and academic skills needed for success. Because of this, they are more likely to experience academic failure and display behavior problems across their school years (Antoine \& Fisher, 2005; Avery, 2001).

Foster children have weaker cognitive abilities, lower academic achievement and classroom performance (Atshuler, 1997). Because of this, children in foster care perform poorly across a range of subjects, including reading, vocabulary, and math. Many foster children enter the school system significantly below grade level in reading and math (Emerson \& Lovitt, 2003; Ferguson, 1999; Sawyer \& Dubowitz, 1994). Foster children generally have lower tests scores on standardized tests and lower school grades than their peers (Aldgate, Colton, Ghate, \& Heath, 1992; Courtney, Terao, \& Bost, 2004; Crozier \& Barth, 2005; Kendall-Tackett \& Eckenrode, 1996; Kurtz, Gaudin, Howing, \& Wodarski, 1993). Because foster children struggle 
academically many of them end up repeating grades in schools (Atshuler, 2003; Emerson \& Lovitt, 2003; Jacobson, 2008; Paulson, 2005).

Special education. There is both over-identification and misidentification for foster children in special education. According to Lips (2007), "as many as $30 \%$ to $40 \%$ of all children in foster care are also in special education, a percentage that is well above the average for the general population" (para. 19). Many foster children may be in need of special services, but special education may not be the appropriate program that will meet their needs. These children might benefit more if they were placed in the regular classroom setting with a focus on their needs, not their special education needs.

Caseworkers don't always have a complete understanding of the educational system and how it works. Because of this lack of understanding, foster children who are in need of special education services do not always get identified (McNaught, 2005). Some foster children may be inadequately monitored causing some to miss the opportunity to receive special education services that would allow them to be successful in school (Vesecky, Woodard, \& Levine, 2005). Foster children who are in need of special services may be at a disadvantage because of not being identified.

Foster children may receive special education placement without ever having the proper interventions implemented. The lack of these interventions could contribute to certain behaviors (Christian, 2004; Jacobson, 2008; Runyan \& Gould, 1985). Under the Individuals with Disabilities Education Act (IDEA), if a child has an Individualized Education Plan (IEP) there are timelines and regulations that a school must follow. Children in foster care may lack a consistent and knowledgeable adult who can advocate on their behalf for special education. The IEP is also part of the missing documents that do not easily follow the foster child. When a 
school doesn't have this legal document to follow, the wait time is academically detrimental to a foster child who is already noted as having overall academic deficiencies.

Many foster parents are unprepared to work through the complexities of the special education system. Many foster children are being poorly served due to lack of parental advocacy, multiple placements in homes and school transfers (Zetlin, Weinberg, \& Shea, 2006).

Mobility. School mobility has been shown to have a significant negative impact on children's academic outcomes and educational success (Schwartz, 1999). The instability caused by frequent school changes and disruptions have harmful, long-term effects on foster children, resulting in academic failure (Schwartz, 1999). Mobile students earn significantly lower test scores on standardized tests (Hofstetter, 1999).

The longer children stay in foster care, the more likely they are to experience multiple placements. Multiple moves sever relationships, interrupt the education process, delay medical care, and cause confusion for the child (The Pew Commission, 2003). Because of frequent home changes, foster children have to adjust to a new school, new teachers and different rules and expectations (Reynolds, 2011). They have to develop new relationships, which according to Gilligan (1999) can include family, peers, care setting, school and even leisure time interests and activities. They can be placed in cities and counties far removed from their original home.

According to Powers \& Stotland (2002) 50\% of foster children change schools at least 4 times after beginning their formal education, with many of them changing schools one or two times during an academic school year. Because of the frequent changes in schools (Avery, 2001), many children may not be immediately enrolled in school when they are placed in a new home (Weinberg, Zetlin, \& Shea, 2006). Multiple moves result in broken relationships, delayed academic progress, repetition of grades, delays in enrollment and transfers of records (The Pew 
Commission, 2003). According to the Child Welfare League of America (CWLA, 2007), "school changes are a significant problem for children in foster care" (p. 2). Changes in schools occur "when children are initially removed from home or when they move from one foster care placement to another" (p. 2). According to CWLA, "the rate of school mobility for children in foster care is greater than their non-foster care peers" (p. 2). On average a foster child could attend up to nine different schools before they reach the age of 18 . It takes a foster child four to six months to recover academically from the disruption of changing schools.

School records. Too many times foster children enter schools without accurate, proper records or any background information. Because of this process, foster children could miss up to a month of school waiting for their school records to be transferred. Schools have no information about behavioral and academic difficulties (Finkelstein, et.al, 2002; Gustavsson, 1991). Many times Child Protective Services don't have adequate school records, they don't keep track of credits and they don't have educational data on foster children.

Because of the lack of information, school principals know very little about the foster child that comes into the school. They can't make informed decisions regarding classroom and academic placement, safety issues and disciplinary boundaries. The services children receive often tend to be fragmented or inadequate (Schwartz, 1999). While there are many people who are involved in the foster child's education, no one appears to be held accountable for the end results.

Unwillingness to share records could be due to Family Educational Rights and Privacy Act (FERPA), which is a federal law that protects the privacy of student education records. While it guides the disclosure and presentation of special education needs, issues regarding 
student achievement of foster children are often in question because school personnel can't get a whole picture of the child's background (Reynolds, 2011).

Absences. Foster children have poorer attendance records than other students. Foster children experience disruptions in their school stability for various reasons. Many children miss days or even months of school before even being placed in foster care due to parental substance abuse, eviction of the biological family, becoming homeless, moving from home to home, lack of clean clothes to wear and the parent or child's need to hide the physical marks of child abuse (National Center for Mental Health Promotion and Youth Violence Prevention, 2010).

Absenteeism continues throughout the foster care placement for many reasons. Foster children are pulled from school regularly for appointments that are scheduled during school hours because of the business hours of various services. Foster children have to miss school because of mandatory court appearances. Foster children also have regular appointments for check-ups, treatments, and progress charting, as well as, counseling and doctor appointments. Foster children also are required to have regular visitations with their biological family. Some of these visits may require travel time if the child is placed out of county. If the child's parent is jailed on charges, these visits may involve lengthy travel time to get to the prison or jail. Because of these and other reasons, foster children experience a high absence and truancy rate in schools.

Behavior, suspensions and expulsions. Foster children display an array of behaviors, just as any child would display. But there are certain behaviors that are more prevalent with foster children. The foster child's dysfunctional behaviors would most likely not exist if it weren't for the losses they have endured, along with the abuse. Most foster children have experienced trauma through physical abuse, neglect, emotional abuse, sexual exploitation, and 
other stresses (Vacca, 2004). Because of this many foster children develop behavioral, physical and emotional disorders that they bring into the classroom (Avery, 2001; Christian, 2007; Conger \& Finkelstein, 2003).

Because of the constant state of instability and insecurity experienced by foster children (Gustavsson, 1991) they tend to have increased aggressiveness, manipulation and acting-out behavior. These children may display withdrawal, temper tantrums, aggressive behavior and poor impulse control which disrupt the learning process in the classroom (Pears, Fisher \& Bronz, 2007). They also display behaviors such as reclusive tendencies, anxiety, and overly submissive behaviors (Atshuler, 1997). Finkelstein, et al. (2002) noted that foster children also tend to either be shy or aggressive. They lack the necessary social skills to cope with situations (Pears, Fisher, \& Bronz, 2007; Vacca, 2004). According to Vacca (2004) and Gustavsson (1991) the foster child feels rejected by peers and adults, has trouble with developing relationships, tends to reenact their abuse, and provoke others to abuse them. They either become a bully or victim (Schwartz, 1999). The feeling of insecurity leads to children defying authority by refusing to listen and doing the opposite of what is asked of them.

The psychosocial effects of child abuse accompany foster children. They struggle with issues that arise from abandonment and grief (Kools \& Kennedy, 2003). Foster children struggle with the foster care status (Gustavsson, 1991). They have feelings of anger, guilt, helplessness, shame and worthlessness. Foster children struggle with identifying emotions such as anger, sadness and happiness (Barahal, Waterman, \& Martin, 1981; Camras, Grow, \& Ribordy, 1983). They struggle with chronic depression, confused identity and an inability to relate to others (Costin \& Rapp, 1984). Foster children also suffer impaired communication abilities and language delays, and engage in self-mutilation (Glastone, 1981; Green, 1978, \& Kinard, 1982). 
Many times foster children rarely receive the services needed to address their unique needs (Kelly, 2002). As a result, they are labeled as behavioral problems. Instead of addressing the behavior problem and offering services, the child is penalized. Foster children are subjected to disciplinary actions, such as, suspensions and expulsions. Foster children are suspended, expelled, and subject to other school disciplinary actions at a very high rate (Smithgall, Gladde, Yang, \& George, 2005).

Outside School Barriers. The outside-school barriers include: (a) child welfare system, (b) foster families, and (c) advocate.

Child welfare system. According to Bruskas (2008), "historically, child welfare has not been held accountable for performance outcomes related to children in foster care" (p. 72). The Casey National Alumni Study (2003) noted that "foster care is a service that is often required when children are seriously abused or neglected" (p. 5). Children in these conditions are removed from the homes and placed in foster care. Foster care is thought of as a temporary situation to assist families suffering through a crisis. The Child Welfare Information Gateway (2011) notes that "reunification is the most common goal for children in out-of-home care" (p. 2). While it is designed as a temporary arrangement, many kids remain in the system permanently.

A state's child welfare system is a complex system that is comprised of rigid policies and procedures. The child welfare system is concerned about protecting children who have been physically or sexually abused or neglected (Finkelstein,et.al, 2002) and to reduce the risk of endangerment for the child (Zetlin \& Weinberg, 2004).

According to Harden (1998) foster children face difficulties within the welfare system that could compromise their development. The Child Welfare system has organizational 
challenges that tend to undermine their ability to provide appropriate case management, services and supports to children and their families (Bass, Shields, \& Behman, 2004). The system is overloaded by a high number of children, the reduction of foster homes, and not monitoring cases due to lack of personnel. Because of worker turnover and high caseloads, it is unlikely that a foster child would have the same caseworker for any length of time (Gustavsson, 1991).

A quality education is lacking for foster children due to an overburdened child welfare system and an education system without a framework for the education professional to understand the unmet needs of foster children (Christian, 2004). Education is an overlooked, low priority in the social welfare agenda of protective services (Blome, 1997). Education often takes a backseat to family, mental health and legal issues surrounding the foster child (Zetlin, Weinberg, \& Kimm, 2003).

There is a lack of cooperation between social workers and educators, and a level of mistrust between both agencies due to differences in perceptions (Conger \& Finkelstein, 2003; Stone, et.al, 2007). Beyond the lack of cooperation there is a lack of coordination. There is often times a fundamental lack of understanding how the other system works. Both child welfare and schools have comparable challenges, but one of the greatest challenges is that child welfare agencies, schools, and other service providers typically do not coordinate their efforts or share information about the children in their systems. Vera Institute (1999-2002) notes that, "if the systems responsible for the well-being of foster children -child welfare, education and the courts - do not place a strong emphasis on the education of foster children, education will fall through the cracks" (p. 3).

Foster families. The foster family often does not have legal guardianship of the foster child. They work with the Child Protective Services to advocate for the child's needs (Reynolds, 
2011). The foster family is responsible for the care and support of the children placed in its care. There are issues of confidentiality that foster parents cannot breach. The Federal Child and Family Services Review (2001) noted that foster parents were often more involved and knowledgeable about children's educational needs than child welfare workers. However, Finkelstein, et.al, (2002) noted that foster parents worried more about the child's behavior and not about education.

Support services that address the needs of foster children and their foster parents are limited. A lack of adequate training, support services and compensation contribute to a shortage of qualified foster parents. Foster families tend to have lower incomes than that of a traditional family or to be unemployed (Jacobson, 2008). Most foster parents often have less than a high school education (Jacobson, 2008). Educational achievement of caregivers is highly related to children's educational success (Emerson \& Lovitt, 2003).

Many educators blame foster families for the difficulties that the foster child experiences in school. They feel that the foster family doesn't take responsibility for the child's behavioral problems, doesn't academics seriously, and are not providing a structured environment for the child to study (Finkelstein, et.al, 2002).

Absence of advocates. Vera Institute (1999-2002) notes that "children in foster care generally do not have an adult who is their educational advocate (p. 4)" even though there are many adults in the foster child's life. They also lack a person who can offer encouragement to them to achieve their educational inspirations. According to the study done by Vera Institute, (1999-2002), children in foster care don't usually have an advocate who identifies nor monitors his or her educational needs. The study also indicates that they lack an adult who knows their way around the school system; helps with the registration and transfer process; monitors grade 
and attendance reports; and makes sure that the child is properly tested, placed in the right grade, and is receiving all the necessary services.

\section{Summary}

During the 1960s laws at the federal level began to focus on the increasing number of foster children in the United States, and it was also during this time that researchers began looking at foster care. Research about foster care has evolved from focusing first on the safety needs of the foster child to the academic needs of the foster child. As the academics became a focus for research, foster children and teachers were more frequently the subject of the studies. However, school principals are still neglected in the research. Even though there have been relevant studies about the academic challenges facing foster children, there is a gap in knowledge in reference to the challenges faced by school principals in identifying and working with this student population. According to the Southern Regional Education Board (SREB, 2009), the burden of school success and individual student achievement are the school principal's to carry.

The plight of foster children is challenging when you consider that they enter the welfare system due to neglect, abuse, or separation from family, experience hardship during care, and lack a constant adult to pursue their educational needs. School principals lack the knowledge, skills and background necessary to tackle these issues and ensure academic success for foster children in their schools (Cormier, 1994; Finkelstein, et al., 2002; Stone, et al., 2007; Zetlin, 2006). School principals need to have an understanding from where these children are coming (Noble, 1997; Schwartz, 1999) and they must become "foster child aware" in order to understand the barriers of educating a child in foster care (Cormier, 1994). They need to be aware and understand the roadblocks that foster children encounter that other at-risk children do not (Cormier, 1994; Finkelstein, et.al, 2002). 


\section{Overview of the Position of the School Principal}

Research done by Hine (2003) notes that the Schools and Staffing Survey of 1999-2000 showed that there were approximately 110,000 principals in the United States. Of those principals, 76\% were working in the public schools. Hine (2003) also noted that school principals comprise a small group when compared to the numbers of teachers in the United States. Also, in this small grouping of principals, elementary school principals make up the majority of public school principals.

Hine (2003) also went on to say that "the age of the principals appears to be increasingly older, on average, and that the average age of entry into the principalship has increased" (p. 274). According to the Rand Corporation (n.d.), the average principal "is in his or her late 40s" (p. 15). There is also a small portion of the public school principals who are over the age of 55 .

Hine (2003) has also noted that "over 99\% of principals in the public schools have had teaching experience" and "that most public school principals have an average of 14 years teaching experience" (p. 272).

Education literature also indicates that there has been significant attention given to the gender composition of school principals. The Rand Corporation (n.d.) notes that "the proportion of female principals is low relative to that of female teachers" (p. 19). Women still tend to be the elementary school principal with men being dominating the secondary school setting. It is also noted that there is a very small proportion of school principals who are members of an ethnic/racial minority.

\section{The Changing Role of the School Principal}

Historically, social and cultural forces have shaped the school principal's role in schools. This role has expanded and become more complex over the years. The school principal was at 
one time the head teacher who assumed the position of controlling the school in addition to teaching the students in his or her care. The role expanded as schools became larger and the school principal became more involved in the areas of management and supervision (Matthews \& Crow, 2003).

School principals were originally expected to keep order in the school, oversee discipline and ensure that students were receiving an education. Over the years, significant attention has been given to how school principals are to function. Goldring and Greenfield (2002) indicate that the image of the school principal has transformed from a "position that was grounded in philosophy and religion in the 1800s, to a highly prescriptive manager concerned with efficiency and focused on functional administrative tasks in the mid-1900s, to a behavioral science perspective in the mid to late twentieth century" (p. 1).

Research shows that schools and school systems have evolved and changed as they are influenced by social, cultural, and political events of the time period. The influences from the decades have inspired different models and methods of leadership roles and styles (Cohen, 1981; Yukl, 1989).

Ideally schools should enrich and enhance the educational opportunities for all children, including foster children. In reality the school principal is strapped with complex sets of regulations and practices which create multiple problems for foster children (Sawyer \& Dubowitz, 1994). While key challenges for improving educational outcomes for foster children are still being addressed, the leadership role of the school principal will continue to emerge and change (Educating Children in Foster Care, 2008).

The school principal is the one person who is responsible for and empowered to oversee the entire workings of the school. He or she plays a critical role in the life and activities of 
school. How the school principal's role mattered and what comprised this role has evolved in response to the dominant themes in the policy context and the academic deliberations of their time (Murphy, 1992). The role is a complex one and over the years it has changed from (a) school manager, to (b) school instructional leader, and to (c) school reform leader.

According to Mydland (2011) "during the 1950s and 1960s most one-room school houses went out of use due to consolidations, demands for better education and better means of transportation" (p. 17). When schools grew from one-room schoolhouses into multiple grades and classrooms, someone was needed to manage the more complex environment. Originally teachers, called principal teachers, would continue to teach and manage the needs of their schools (Coffin, 2008). At this time, school principals were only expected to be experts on teaching and learning.

As the schools continued to grow, principal teachers evolved into full time administrators, giving up the teaching because of the management demands placed on them. The role expanded to include management of the school, minor administrative duties, discipline, school maintenance, financial operations, student scheduling, personnel supervision, public relations, school policy, and coordination of the instructional program (Beck \& Murphy, 1993; Coffin, 2008).

A change in the duties and responsibilities of principals came during the latter part of the twentieth century. In the 1980s school principals were shifting their role from managers to instructional leaders (Phillips, 1996). Schools were feeling the pressure of being held more accountable for the performance of their students on state assessments. Legislators mandated that school principals improve the instructional programs in their schools and therefore, school 
principals became responsible for the teaching and learning in their schools. It was their job to monitor instruction and to help teachers improve their teaching (Phillips, 1996).

As schools faced the pressure of improving teaching and learning, the duties and responsibilities of school principals changed again. The 1990s saw the role of school principal shift with more focus on goal-setting, planning, financial management, marketing, public relations, and compliance with accountability. School principals shouldered the responsibility for leading school reform that would increase student achievement.

Searching for the roots of care in leadership. According to Begley (2006), "leadership by definition refers to practices that extend beyond the usual procedural context of organizational management" (p. 570). The concept of school leadership is always evolving and even overlapping at times. According to King (2006), the image of the school leader has changed from that of a manager focused on efficiency and administrative tasks in the 1990s to an administrator with unprecedented responsibilities, challenges, and tasks. Research has shown that various leadership styles have emerged and that leadership styles continue to change as the needs of society change (D’Ambrosio, n.d.).

According to Spears (2010) there is a movement away from the more traditional autocratic and hierarchical models of leadership in education. Begley (2006) indicates that the "traditional dualistic portrayal of management and leadership practices" (p. 570) are obsolete for today's school leaders. There is a shift towards leadership that helps develop relationships and caring behavior. Begley (2006) notes that leadership today needs to be "an integrated image of leadership and management... a form of leadership that acknowledges and accommodates, in an integrative way, the legitimate needs of individuals" (p. 570). This research focuses on caring leadership and this section includes an exploration of the roots of caring in leadership. 
Leadership for today must become something more relevant to meet the unique needs of foster children in the schools. The following section will look at (a) leadership eras, (b) leadership styles, (c) leadership theories, (d) the principal's role, and (e) caring leadership.

\section{Leadership Eras}

There are six leadership eras, and each of the eras left a mark on the role of leadership. During the Scientific Era the focus was on efficiency and increasing production (Martin \& Jenkins, 2008) while the Human Relations Era focused on people and relationships with people. The Social Systems Era saw schools as open-systems, where they constantly interacted with their environments (Lunenburg, 2010). The Contingency/Situational Era focused on leadership adapting to the needs and structure of the organization. The Transformational and Enlightened Leadership Era focused on moving schools from old routines into a new age that would address the needs of the times. Table 1 gives an overview of the leadership eras and the theorists who contributed to them: 


\section{Table 1}

Leadership Eras, Focus and Theorist

\begin{tabular}{|c|c|c|}
\hline Years/Era & Focus & Theorist \\
\hline \multicolumn{3}{|l|}{$1910-1935$} \\
\hline \multirow[t]{3}{*}{ Scientific Management } & Define goals & Fredrick Taylor \\
\hline & Coordinate labors to meet goals & \\
\hline & Increase productivity & \\
\hline \multirow[t]{3}{*}{ Administrative Theory } & Focus on job \& work & Henri Fayol \\
\hline & One supervisor & \\
\hline & Control & \\
\hline \multirow[t]{3}{*}{ Bureaucratic Organization } & Formal rules & Max Weber \\
\hline & Division of labor & \\
\hline & Formal hierarchical structure & \\
\hline \multicolumn{3}{|l|}{$1935-1950$} \\
\hline \multirow[t]{3}{*}{ Human Relations } & Interrelatedness & Mary Parker \\
\hline & Teaching done by leading & Follett \\
\hline & Organizations exist to serve people & \\
\hline \multirow[t]{3}{*}{ Hawthorne Experiments } & Man motivated by social needs & George Mayo \\
\hline & Work group influences behavior & \\
\hline & Need for social relationships on the job & \\
\hline \multirow[t]{3}{*}{$\begin{array}{l}\text { Maslow's Hierarchy of } \\
\text { Needs }\end{array}$} & $\begin{array}{l}\text { Human needs arranged in hierarchical } \\
\text { order }\end{array}$ & Abraham Maslow \\
\hline & Basic needs/higher order needs & \\
\hline & $\begin{array}{l}\text { Motivators determined by placement } \\
\text { on pyramid of need }\end{array}$ & \\
\hline \multirow[t]{2}{*}{ Theory X \& Theory Y } & $\begin{array}{l}\text { Theory X manager views employees } \\
\text { in negative way }\end{array}$ & Douglas McGregor \\
\hline & Theory Y manager views employees & \\
\hline \multicolumn{3}{|l|}{ 1950-1965 } \\
\hline Social Systems & $\begin{array}{l}\text { Human behavior requires consideration } \\
\text { of entire situation }\end{array}$ & Kurt Lewin \\
\hline \multirow[t]{2}{*}{ Force Field Analysis } & Individual seen as product of nature & Jacob Getzels \& \\
\hline & Organizations seen as social system & EgonGuba \\
\hline Organizational Behavior & Organizational roles \& expectations & \\
\hline
\end{tabular}


Table 1 Continued

1963-1980

Contingency/Situational

Grid System

Situational Leadership

1980-1995

Transactional leadership

Transformational leadership

1995-Present

Transformational \&

Enlightened Leadership
Leadership style relates to how the leader achieves production through people

Leader should adapt his style to the situation Leader should rely on relationship behavior, not task behavior

Transactions between leader \& workers are in the form of money, praise or other rewards

McGregor Burns
Robert Blake \& Jane Mouton

Pat Hersey \& Kenneth Blanchard

Strong relationship with workers

Share in vision, goals \& principles

Instructional leaders

Improve professional practices

Work with curriculum \& instructional

reform

Encourage teacher growth

Share instructional leadership with

teachers

Involve teachers in educational decisions

Note. Adapted from G. Martin \& S. Jenkins, 2008; and F. Dembowski, 2006.

From the $19^{\text {th }}$ century up to the late $20^{\text {th }}$ century the Scientific Management, Bureaucratic Management, and Administrative principles were sometimes referred to as the Classical Perspective of management practices. The leadership theory of this time period was leaderdominant. The focus was on procedures, techniques, methods and practices. The organizational rules were in place for control, how to deal with specific behavior, and problems concerning personnel management (Witt, 2007). The scientific management perspective suggested that schools should operate like commercial businesses, thus becoming efficient and more businesslike (Matthews \& Crow, 2003). The school principal as a manager of the school was seen as 
extremely important in the running of the school (Sergiovanni, 1995). During this time period the school principal's role expanded to include the organization and management of the school, some administrative tasks, discipline, some teaching, school maintenance and supervision of personnel (Beck \& Murphy, 1993).

The leadership eras that are most important for this research are the Human Relations Era and the Transformational and Enlightened Leadership Era because the concepts placed importance on the needs, attitudes, and social interactions of people (Daft, 2010).

During the 1970s and the 1980s, school principals were viewed as both instructional leaders and human resource agents (Sergiovanni, 1995). The Humanistic Perspective of management focused on the importance of understanding human behavior. Begley (2006) notes that "in order to lead effectively, individuals in any leadership role need to understand human nature and the motivations of individuals in particular" (p. 571). While most theories focused on the relationship between leader and the organization, Mary Parker Follett (1869-1933) thought somewhat differently than the theorists of her day. Follett (1924) felt that "the greatest need of today is a keen, analytical, objective study of human relations" (p. ix). Her concepts of leadership focused on respect for people, for human dignity, avoiding abuse of power and developing the individual (Mele', 2006). She did not like the command-style hierarchy of organizations. Follett (1924) stated that "good intentions are not sufficient" (p. xii), but instead looked at relationships between the leader and the followers.

Follett's belief was that caring should be integrated into the decision making process (Mele', 2006). She also noted that leaders must deal fairly with the personal side of the business. When leaders treat their workers in a proper way, the business is successful (Mele', 2006). She stressed that leaders must make proper use of power. She embraced the concept of power with 
people instead of power over people. She believed that there should be a focus on cooperation, not on confrontation. Follett also focused on preservation of the integrity of each individual. Follett believed that by encouraging personal development a leader would see positive relationships develop that would better the organization.

Follett felt that leaders were in a position that would allow them to make a positive contribution to the social welfare of people and to the culture. She noted that a caring leader is one who works with a sense of service to society and is guided by standards of conduct. The role of the caring leader is used in service of others, not just for one's own purpose. Table 2 illustrates Follett's ideas on the characteristics that distinguish leaders and the approaches they use to lead:

Table 2

Contemporary Management

Characteristics Approach

Dynamism The organization is a complex dynamic social relation influenced by reciprocal reactions

Empowerment Give employees opportunities to nurture or develop their own power

Participation Coordination of the contribution of each individual for a greater good

Leadership The leader is the person who can show that his/her orders are determined by the situation

Conflict Integration is the only solution to conflict

Experience Managers should share experiences and compare and discuss conclusions with others

Note. Adapted from Mary Parker Follett, 1924. 
In the 1970s Follett's ideas re-emerged. Follett's idea was that leaders should develop relationships and people, not necessarily focus on the task that needed to be completed (Dembowski, 2006). Follett felt that leaders should nurture the integrity of the individual: We need a technique of human relations based upon the integrity of the individual. We have heard too much about the collective life as an aim in itself. What we care about is the productive life, and the first test of the productive power of the collective is its nourishment of the individual. (p. 92)

As school principals began to work toward developing relationships, their role took on a new form. During this time period, school principals were expected to relate well to people, facilitate positive interactions and take on a leadership role that moved out into the community (Hoppey, 2006). However, this was a short-lived expectation for the school principal as the focus in the 1980s shifted to instructional leadership. Hoppey (2006) asserts that during this time the school principal moved away from developing relationships to "coordinating staff development, as well as, curriculum development while leading a school toward improved educational achievement" (p. 3).

\section{Leadership Styles}

Leadership style is the way in which a leader interacts with others in various situations. It is the manner and the approach one uses in providing direction, implementing plans and motivating people. There is no best leadership style for all situations. Many times the leadership style will depend on the situation at the time (Brennen, 1994).

There is a large body of literature that looks at the various types of leadership styles and the impact they have had on education (Sergiovanni, 1995). Leadership style reflects a leader's behaviors. One looks at the traits and behaviors of a leader and then categorizes his or her 
leadership style. The common theme within each of the leadership styles is that the leader tends to be the one setting the tone for the school (Robertson, 2009).

\section{Leadership Theories}

Leadership has evolved over time, as have its theories. Leadership theories explain the concept and practice of leadership (Wolinski, 2010). The theories provide a framework that allows an understanding of leadership as: (1) a process or relationship, (2) leadership as a combination of traits or personality characteristics, or (3) certain behaviors or leadership skills. The common factor in all the theories is that the leadership role is a process that involves influence with a group of people toward a common goal (Wolinski, 2010). The periods of theories are shown in Table 3:

\section{Table 3}

Periods of Leadership Theories

\begin{tabular}{|c|c|c|}
\hline Leadership Theory & Theorist & Traits \\
\hline $\begin{array}{l}1900 \\
\text { Great Man }\end{array}$ & Carlye & Leaders are born, not made; arise when there is a need. \\
\hline $\begin{array}{l}\text { 1920-1930 } \\
\text { Trait }\end{array}$ & Jenkins & $\begin{array}{l}\text { Leaders have superior or endowed qualities; natural ability } \\
\text { to lead; traits that differentiate them from followers. }\end{array}$ \\
\hline $\begin{array}{l}1950-1960 \\
\text { Behavioral }\end{array}$ & McGregor & $\begin{array}{l}\text { Leaders can be made, rather than born; successful } \\
\text { leadership is based on learnable behavior. }\end{array}$ \\
\hline $\begin{array}{l}1960-1970 \\
\text { Situational }\end{array}$ & $\begin{array}{l}\text { Hersey \& } \\
\text { Blanchard }\end{array}$ & $\begin{array}{l}\text { Leaders act differently in each situation; situation } \\
\text { determines who is a leader; different leadership behaviors } \\
\text { for different situations. }\end{array}$ \\
\hline $\begin{array}{l}1970 \\
\text { Servant }\end{array}$ & $\begin{array}{l}\text { Follett } \\
\text { Greenleaf }\end{array}$ & $\begin{array}{l}\text { Leaders are responsible for followers; have a responsibility } \\
\text { to society; have a responsibility to those who are } \\
\text { disadvantaged. }\end{array}$ \\
\hline $\begin{array}{l}1980 \\
\text { Transactional }\end{array}$ & $\begin{array}{l}\text { Burns \& } \\
\text { Bass }\end{array}$ & $\begin{array}{l}\text { Employees are motivated by reward \& punishment. } \\
\text { Subordinates are not self-motivated; obey orders of } \\
\text { superiors. }\end{array}$ \\
\hline
\end{tabular}


1980-1990 Burns \& People follow a person who inspires them.

Transformational Bass Leaders with a vision \& passion can achieve great things.

Note. Adapted from R. Bolden, J. Gosling, A. Marturano, and P. Dennison, 2003.

Leadership theory examines what makes successful leaders excel in what they do

(Robertson, 2009). The focal point of the early theories was that leaders possessed certain innate traits which combined to yield effective leadership, such as the Great Man Theory (Daft, 2005).

Trait theories contended that leaders were born with superior qualities that separated them from followers. In the early 1900s behavioral and social scientists felt that leadership could be taught and developed (Nielsen, Randall, Yarker, \& Brenner, 2008). These theories were no longer looking at the traits of the leader, but instead, the focus was on the behavior of the leaders (Daft, 2005). The later theories focused on the relationship between the leader and the followers (Robertson, 2009). No matter what theory is used to explain it, leadership is the vital link to the success of schools.

Throughout the twentieth century, the role of the school principal has been like a revolving door. At one time school principals were groomed to be bureaucratic executives, ten years later they were viewed as humanistic facilitators, and years later they are expected to be instructional leaders (Beck \& Murphy, 1993). A review of literature shows that the role of the school principal consists of many things including, management, communication, school culture, vision development and risk taking. The role is one that is constantly shifting as the school principal balances all the tasks that are expected (Hallinger, 2003). According to DarlingHammond (1998) it is a role that is complicated due to "an increasingly complex society" and "the most diverse student body in our history" (para. 1). Effective leadership skills are necessary in order for schools to expand beyond their traditional boundaries (Green, 2001). 
According to King (2006) given the importance of leadership, it comes as no surprise that research has determined that an effective school principal is necessary in order for schools to be successful in meeting the needs of all the students. King also notes that school principals play a vital role in determining the success of all the students and in developing a relationship between the students and community. However, Noddings (1992) feels that the traditional organization of schooling does allow the school principal to meet the needs of today's society. Her view is that "too many of us think that we can improve education merely by designing a better curriculum, finding and implementing a better form of instruction, or instituting a better form of classroom management. These things won't work" (p. 173).

According to Beck \& Murphy (1994) there is "a growing awareness of the complex dilemmas facing educational leaders" (p. 3). While ensuring the educational success of students is a challenge facing the school principal, it is also a dilemma because of the diverse student population in the schools. Many students have special needs that are both academic as well as non-academic. Beck \& Murphy (1994) note that the tasks of the school leader have "moral dimensions, because they require, at every point, working with, protecting, and honoring all people" (p. 11). In order to meet this challenge, the role of the school principal needs to develop into a caring leadership role. According to Brown (2004) "the link between caring and learning is very strong" (p. 30).

\section{Caring Leadership}

\section{What is Caring?}

Trying to define caring leadership is not an easy task. Beck \& Newman (1996) noted that because there are multiple meanings attached to caring, it makes defining or recognizing it very challenging. Beck (1994) stated "true caring occurs when persons relate to others in ways that 
honor and encourage the healthy unfolding of all types of development" (p. 6). Caring, according to Irvine (2001) is a belief that educators and children should be caring members of society. Mayeroff (1971) feels that caring is a process of helping a person to grow and actualize him or herself.

Gilligan (1982) examined caring as a value and ethical obligation. In her studies, Gilligan suggests that there are two distinct voices in conversations about morality. One voice speaks from an ethic of justice, which is concerned with fairness, equality, rules and regulations. The other voice is an ethic of care, which is focused on nonviolence and no harm to anyone. An interesting twist is that she sees caring as gender related. In her work she identifies caring as being flexible and adhering to certain nonconformity to arbitrary rules, and pairs it with women. Noddings (1984) defines care as "an operation of deep concern that carries us out of ourselves and into the lives, despairs, struggles, and hopes of others" (p. 5). Noddings (1984) states that "we are obligated to do what is required to maintain and embrace caring" (p.94). Because schools are typically organized through a uniform set of rules and regulations, it raises the question as to whether principals can care and if schools can be caring environments.

Noddings (1984) feels that caring has two focuses: (a) someone cares for another if she has regard toward that person, and (b) caring means to protect someone. She also echoes Gilligan's work by agreeing that caring is not something that is guided by rules, but instead by affection and regard. Caring is not something that can be scripted; it has to evolve from one's sense of what is important.

\section{Caring Leadership}

According to Hayes, Ryan, \& Zseller (1994) the "effectiveness of our school systems has been called into question by a decade of governmental, educational and private sector 
reports... The emotional condition of students and their receptivity to teaching received very little attention in these reports" (p. 1). The emphasis in education has been and continues to be academic achievement while the "moral, ethical and human aspects of education are ignored" (p. 2). Clark (1993) notes that "an awareness of the needs of others is rarely seen as part of the curriculum" (p. 38).

Hayes, Ryan, \& Zseller (1994) note that "the concept of caring has been discussed under various terms: compassion, feeling, emoting, love, prizing, valuing, concern, confirmation and recognition of another" (p. 3-4). During the 1970s Beck \& Murphy (1993) noted that there was a period when the school principal was described as a community leader and a facilitator of positive relationships. School principals started dealing with situations that were not academic in nature. They dealt with problems in society, such as teen pregnancy, drug abuse, alcoholism, along with decreasing attendance (Coffin, 2008). This was a short-lived time period due to the changing expectations of the role that school principals should play in the school setting. The pressure on schools was to demonstrate improved student achievement. Because of this the school principal was to create a climate that was working towards improving student performance and accountability. In order to meet these expectations, the school principal had to redefine his/her role to become the primary learner in the school and strive for excellence in education. As the school principal developed into an instructional leader in the school instructional quality became the top priority of the school.

Over the past 20 years the push in education has been testing and accountability. Gordon, Benner, \& Noddings (1996) noted that because No Child Left Behind mandates that schools focus on academic goals, children are saying that nobody cares about them. Missing 
from the endless list of responsibilities and expectations for the school principal is the concept of the school principal as a caring leader.

Noddings (1992) noted that the traditional model of schools in which the needs of the organization were met instead of the needs of the individuals, is not suitable for our diverse student population today. According to Noddings (1984) the ethic of care in education is not an option, but is a moral obligation. Noddings indicates that schools must provide "caring and continuity for students" (p. 14). Researchers have attempted to find an approach that meets both the academic and the moral obligations of education as school principals struggle to ensure that students make the academic gains that the law requires (Coffin, 2008).

\section{Developing Relationships through Caring Leadership}

Noddings (1992) indicates that male and female school principals need to throw out the bureaucratic inflexibility and commit to developing students' academic, social and emotional abilities through caring leadership. Noddings (1992) also notes that the notion that "all children can learn" is a "naïve and dangerous" thought (p. 30). She continues her argument stating that "educational concerns today focus on groups instead of individual children" (p. 41). Noddings also believes that schools will not be successful in reaching the academic goals they have set "without attending to the fundamental needs of students for continuity and care" (p. 64). According to Noddings (1992) caring describes a relationship. The role of a caring principal should be to meet the needs of the students, regardless of their race, class, or gender and to transform schools into caring communities. Noddings (1984) emphasized that "caring must go beyond an attitude and actualize itself in some kind of action" (p. 92). In order for this to take place there has to be a focus on developing caring relationships. 
Caring leadership focuses on the relationships rather than on rights and rules. By developing relationships with students, the principal can become aware of the needs and feelings of the students in their schools. School principals need to be aware of and value the diversity in their student population. Follett (1924) supported this concept, as shown in the following quote: What people often mean by getting rid of conflict is getting rid of diversity, and it is of the utmost importance that these not be considered the same. We cannot get rid of diversity; we must face life as it is and understand that diversity is its most essential feature (p. 94).

Understanding diversity allows the school principal to become sensitive to the social, emotional and academic needs of all the students (Glanz, 2010). The school principal also becomes the role model for the staff, which in turn, helps to develop a caring community in the school for students. Through these relationships the students can feel safe, valued, and competent (Kaplan \& Owings, 2000).

\section{Leadership Instrument Survey}

There has not been a survey instrument found that addresses caring leadership. This researcher has explored research done by Dr. Lynn Beck and Dr. Joseph Murphy. Their research interest has been in moral and ethical issues in education and educational administration. Dr. Lynn Beck, a noted expert on caring and ethical leadership, (personal communication, August 8, 2012) indicated in an email that:

I have looked and looked but I'm not finding surveys. They must be out there somewhere, but the only surveys I can find are surveys of children's perceptions of care. I did find a couple of things that referred to teachers' perceptions of principals. The survey asked them to rate principals using Kouzes' and Posner concepts. 
Kouzes and Posner developed the Leadership Practices Inventory. It is an instrument that is administered only to those who are in a position to directly observe someone as a leader. This instrument measures five leadership practices: Challenging the Process, Inspiring a Shared Vision, Enabling Others to Act, Modeling the Way and Encouraging the Heart. The section on Encouraging the Heart was looked at to see if the questions related to caring leadership. The six questions for this section focused on praising and recognizing people, not on caring leadership.

The following studies were reviewed and included surveys and/or interviews: One study, The Principal's Role and School Structure, done by Mohajeran \& Ghaleei (2008) was conducted to investigate what impact a school's principal had on, among other things, student outcomes. The study used a mixed method approach through questionnaires and semi-structured interviews, along with school policy documents, newsletters, annual reports and management plans. It was multiple case studies using four schools. The study found that it was not so much the structure of the school that impacted students, but instead, it was the principal who made the difference. The results from this study also indicate that in-school decision making is limited by policies and legislation of the government, the Board of Education and budget constraints.

Another study, The Secondary Administrators' and Counselors' Collaborative Leadership and Involvement of Foster Parents in Special Education Decision-Making study, was a qualitative study conducted by Dr. Palladino and Dr. Haar, two former school principals. This qualitative study was conducted through semi-structured interviews with five secondary school principals and assistant principals and two secondary school counselors. The purpose of this study was to determine if there was a link between the participants' collaborations and foster parent engagement in special education decision making. The findings from this study confirmed that there are collaborative challenges present among foster care populations. While 
the study did not focus on caring leadership, it was noted by the researchers that "school leaders are best poised to make and implement policies that could resolve the deleterious educational deficits present among foster care populations" (p. 2).

John Bartlett (2008), a doctoral student at Liberty University, conducted a correlation study of specific instructional leadership practices and student achievement on the Tennessee Gateway Tests. The purpose of the research was to determine if there was a relationship between specific leadership practices of school principals and student achievement. The researcher used the Instructional Leadership Practices Survey, a survey instrument developed by the researcher to gather the information. The survey was administered to high school principals that were at schools that were identified as economically disadvantaged. The study also focused on school size, noting that research indicated that students performed better when in a small school. He also restricted the population surveyed by allowing only principals to participate that had been the administrator of the school for three years or more.

The collected data indicated that for this population of Tennessee principals there was not a relationship between specific principal leadership practices and student achievement. It also indicated that the average principal spent less than 10 hours per week monitoring instruction in the classrooms.

The Stakeholder Perception Surveys (AdvancED Surveys, 2011) are perception surveys offered to districts and schools to gather data from school stakeholders. The surveys are administered to parents, staff and students and the data is used to change plans and goals for the school. In the study, What Keeps Children in Foster Care from Succeeding in School, the data was gathered through semi-structured, individual interviews with foster children, foster parents, welfare workers and teachers. The focus of the study was to bring awareness to educational 
system and the welfare system of the many problems that foster children face in school. The results confirmed that "staffs sometimes have the least awareness of a child's foster care status and of the circumstances surrounding a child's home life" (p. 35). It was also noted that school staff demonstrated a "strong reluctance to view the experiences of foster children as being different from those of the general population" (p. 35).

Another study that was conducted by the Casey Family Program, Assessing the Effects of Foster Care: Early Results from the Casey National Alumni Study (2003) provided data from former foster children. Data for this study were collected between 1966 and 1998. Researchers gathered information through case record reviews and interviews with foster children who had exited from foster care. The results indicated that schools, foster parents, and policymakers need to focus on providing foster children with educational supports and ensure permanence and stability in their care.

A quantitative study by Watson-Davis (2009) entitled Teacher's Understanding, Perceptions, and Experiences of Students in Foster Care: A Forgotten Population, was done in order to "better inform and provide an opportunity to discover what it will take to educate teachers about the variety of circumstances that their students in care are contending with" (p. 13). The results from this research were to be used to determine the necessary support systems for teachers and foster children to ensure school success at all levels.

The researcher structured a 26 closed-ended question survey from the design used by Ortiz (2006). The survey used a Likert-scale and also included yes-no questions. The results from the study indicated that teachers don't understand the foster care system and that they lacked training to identify and implement appropriate counseling strategies, academic interventions, and programs to address early identification and working with foster parents. 
A qualitative study, School Experiences of Foster Children as Seen through the Eyes of Teachers, by Bonneau (2003) focused on foster children in the school setting. The study interviewed school teachers to determine how they perceived foster children and to assess how their perceptions impacted their relationships with foster children. The results from the study indicate that teachers feel that working with foster children is "tiring, frustrating and draining" (p. 73), and that in order to meet the needs of foster children they need proper training and ongoing professional development. They also indicated that there is a need for support from the school system and access to appropriate resources.

Because there is not a survey available to gather the information needed for this study, the survey for this research will be developed by the researcher.

\section{Summary}

Social, political and economic changes have transformed the structure of our society, which in turn has had an impact on education. This change has brought perplexing problems related to the quality and delivery of education. Begley (2006) indicates that "as our communities and societies become more diversified, school principals must become more sophisticated in their leadership, and more sensitive to the value orientations of others" (p. 582). Beck \& Murphy (1994) support the concept that "schools must play a key role in the development of a just and caring society" (p. 13). Halsey (1996) and Greenberg (1995) both noted that a successful school is one that has a caring principal in charge. When students know that the school principal cares about them, they work hard, achieve more, and feel accepted and respected. A new emerging role that school principals must embrace is that of caring leadership. The caring leader is one that is invested in the children that are in the school building. As a 
caring leader, school principals have the opportunity to develop strong commitments to things that are important and to also be role models within the school and the community.

School principals are still confronted with issues that they have not been trained in and for which there are no clear answers (Glanz, 2005). One area that illustrates the challenges of unfamiliar ground is uncertainty over the role of the school principal and the leadership strategies that should be guiding the change. While there has been some restructuring, along with some new leadership paradigms, many of the old models have been left in place. Leaders seem to struggle when trying to find the right balance between managing the routine, technical functions of the school operation and leading the school in a focused direction (Manning, n.d.).

The role of the caring principal focuses on the principal developing caring relationships and supporting students to do their best. The challenges of improving performances of both students and teachers, addressing a host of social problems and being the instructional leader in the school are still going to be on the priority for school principals. The principal is still going to be expected to succeed rather than to serve the needs of foster children (Johnson, Livingston, Schwartz \& Slate, 2000).

\section{Supports for Schools}

\section{Policy and Programs}

According to the research done by the West Virginia Out-of-Home Care Educational Task Force (2005) "a seamless continuum incorporating all aspects of care and education for outof-home children presently does not exist in West Virginia" (p. 8). Policies need to be put in place that improve, not hinder, the educational outcomes of foster children. Policy needs to be established to support students who are most in need. Federal, state and local governments need 
to provide incentives to teachers for developing and implementing innovative programs and interventions to help foster children succeed (Vacca, 2004).

\section{Collaboration Between Agencies}

There are few mechanisms that exist to ensure successful collaboration between the public school system and the child welfare system. There is a lack of understanding in the role of each agency, the procedures and laws that govern them (Altshuler, 1997). Agencies do not share information concerning the foster child because of confidentiality. While decisions made about a foster child are done by a variety of people, such as, attorneys, biological parents, juvenile court, judges, child welfare agencies and foster parents (Gustavsson, 1991), the sharing of the information is not there.

Research notes that as long as Child welfare and school systems continue to operate in isolation, the educational needs of a child in foster care will remain unmet. Altshuler (2003) calls for a more collaborative working relationship by all parties involved to develop an understanding of the barriers experienced by a child in foster care. There needs to be better communication lines between schools, welfare agencies and foster parents (Vacca, 2004). When a foster child is being enrolled in a school, they should be identified as such (Gustavsson, 1991). School principals should be able to obtain background information on foster children (Emerson \& Lovitt, 2003). Welfare social workers should take time to discuss with the school staff the life situation and history of a child. In order to have a positive working relationship established with the youth's caregivers (Emerson \& Lovitt, 2003), a positive relationship has to develop between school principals and the foster parents. Educational liaisons for child-welfare agencies need to be established (Jacobson, 2008; Weinberg, Zetlin \& Shea, 2006). There needs to be an 
educational advocate (Finkelstein, et.al., 2002). Social workers need to be able to assist in the evaluation of psychosocial needs of foster children (Gustavsson, 1991).

\section{Specialized Training for School Personnel}

School principals need to have specialized training in order for them to work with the foster child (Jacobson, 2008). There needs to be professional development and workshops for school principals that focus on the barriers and characteristics of foster children.

Orientation programs and supportive, short-term individual and group counseling should be established in order to help school principals develop an environment that is safe for the atrisk, educationally vulnerable foster child population in the schools today (Gustavsson, 1991). Schools must begin to offer comprehensive, coordinated services and reach out to the staff in the welfare system (Gustavsson, 1991). 


\section{Chapter Three}

\section{Research Design}

\section{Introduction}

The literature review shows that there is a growing concern that "children in foster care represent one of the most vulnerable, academically at risk populations in the United States" (Zetlin, Weinberg, \& Kimm, 2004, p. 421). However, because of limited research in the area of foster children and their educational experiences, there is not adequate information on how to identify and address the barriers that interfere with educational success for foster children.

Research has demonstrated the importance of supporting education for children in foster care (Altshuler, 1997); however, there is limited research exploring the experiences of elementary school principals working with foster children in their schools. There is not adequate information on how school principals identify barriers that interfere with the educational success of foster children.

The purpose of this study is to examine West Virginia Title I elementary school principals' perceptions of barriers that interfere with the delivery of educational services to foster children. This chapter includes the following sections: (a) research paradigm, (b) purpose of the study, (c) study population, (d) survey instrument, (e) structured interview, (f) interview questions, (g) eight elements of survey design, (h) Likert Scale, (i) reliability and validity, (j) panel of experts, (k) pilot testing, (l) data collection, (m) data analysis, and (n) documentation.

\section{Research Paradigm}

All research needs a design or a structure before data collection or analysis can be considered. The purpose of the research design is to "collect data from the real world, and then using these data to draw conclusions about what is being studied" (Field, 2005, p. 1). 
Quantitative research is "designed with the intention of making generalizations about some social phenomena, creating predictions concerning those phenomena and providing causal explanations" (Glense, 2006, p. 4). Methods for gathering information are "designed to be objective and to keep the researcher removed from subjects to avoid influencing behavior and responses" (Glense, 2006, p. 4). According to Creswell (1998) it is an inquiry into a social or human problem based on testing a theory composed of variables, measured with numbers, and then analyzed with statistical procedures to determine if the generalizations of the theory hold true. Jenkins (2009) has noted that a quantitative research approach gives results in precise measurements and tends to be the preferred method. The quantitative research design allows the researcher to collect data in the form of numbers and statistics and then to "count and classify, and build statistical models to then explain what is observed" (Jenkins, 2009, para. 1).

Qualitative research generates non-numerical data. It is a technique of watching, listening, and understanding. It focuses on gathering verbal data which are analyzed in an interpretative manner. Qualitative researchers "focus on in-depth, long-term interactions with relevant people in one or several sites" (Glense, 2006, p. 5). The researcher is looking for patterns in the data, but they do not "reduce the interpretations to a norm" (Glense, 2006, p. 5).

While researchers have had many discussions about which research approach is the best, many view the quantitative research design as the best to use because of the precise measurements and controlled environment of experiments (Jenkins, 2009; Lash, 2008). According to Bevea and Nicoll (1997), the research and how it is framed will largely determine the researcher's choice of design. Lash (2008) indicated that quantitative research is best for confirming and clarifying information.

This study uses a quantitative research design for the following reasons: 
- Quantitative research offers accurate measurement and analysis (Jenkins, 2009).

- The problem is defined.

- Descriptive research assesses both attitudes and perceptions of the participants.

- The results are statistically reliable (McCullough, 1998).

- Quantitative research involves data which are typically numeric and collected through surveys.

If participants indicated on the survey that they were willing to be interviewed, the researcher used a qualitative method to answer the second question for the following reasons:

- Data are collected by the researcher through an interview (Miles \& Huberman, 1994).

- The researcher is the primary instrument for data collection (Patton, 1990).

- The researcher uses open-ended questions to gain a rich understanding of the problem (Merriam, 1998).

\section{Purpose of the Study}

The purpose of this study is to examine Title I Elementary school principals' perceptions of barriers that interfere with the delivery of educational services to foster children in West Virginia public schools. The study determines if a relationship exists between identified variables by addressing the following questions:

1. What barriers do principals in West Virginia Title I elementary schools perceive exist for foster children?

2. Is there a relationship between the principals' perceptions of the barriers in the ratings of the Barriers in Educating Foster Children survey instrument as related to the 
demographics of the participants? The demographics are (2a) years of experience as a principal; (2b) years as principal at that school; (2c) gender; and (2d) region?

3. What experiences have principals in West Virginia Title I elementary schools had with foster children?

According to Trochim (2006) a variable is any entity that can take on different values. Quantitative designs have at least two types of variables: independent and dependent (Creswell, 2004). The independent variable ( $\mathrm{x}$-value) can be manipulated, measured or selected prior to measuring the outcome or dependent variable (y-value). The independent variables for this study include: (1) years of experience as a principal, (2) years of experience in the school, and (3) gender. Dependent variables are influenced by one or more independent variables (Creswell, 2004). The dependent variable for this study is the Mean of the 28 items overall and the eight categories.

\section{Study Population}

The West Virginia Board of Education has established eight Regional Education Service Agencies (RESA) that serve the 55 West Virginia counties. RESA works with the counties to improve administrative practices and teaching strategies. These eight regions are represented in this study. The study population, as illustrated in Table 4, will consisted of West Virginia elementary school administrators who work in elementary Title I schools in each of the state's eight regions. West Virginia elementary schools are defined as "a school that has any grade configuration including Kindergarten to $7^{\text {th }}$ grade, but not grade 8" (WVDE Policy 2320, 2011, 4.2). The researcher was able to obtain information about individual elementary schools from the West Virginia Educational Informational System Data On-Demand School Profile. Table 4 
has the counties identified for each of the eight regions. It also indicates how many elementary

Title I principals are employed in the school systems for those regions.

\section{Table 4}

Title I Elementary Schools in West Virginia (WVDE)

\begin{tabular}{llc}
\hline Region & Counties & Principals \\
\hline I. & McDowell, Mercer, Monroe, Raleigh, Summers, Wyoming & 44 \\
II. & Cabell, Lincoln, Logan, Mason, Mingo, Wayne & 38 \\
III. & Boone, Clay, Kanawha, Putnam & 37 \\
IV. & Braxton, Fayette, Greenbrier, Nicholas, Pocahontas, Webster & 31 \\
V. & Calhoun, Jackson, Pleasants, Ritchie, Roane, Tyler, Wirt, Wood & 31 \\
VI. & Brooke, Hancock, Marshall, Ohio, Wetzel & 20 \\
VII. & Barbour, Doddridge, Gilmer, Harrison, Lewis, Marion, Monongalia, & 57 \\
& Preston, Randolph, Taylor, Tucker, Upshur & \\
VIII. & Berkeley, Grant, Hampshire, Hardy, Jefferson, Mineral, Morgan, Pendleton & 38 \\
& & \\
Total & 55 & 296 \\
\hline
\end{tabular}

The Title I program provides federal funding to schools that are identified as having a large percentage of children from low-income families. The purpose is to target students who are at-risk of failure academically and provide supports and enrichment services to those students (U.S. Department of Education, 2011).

Research has shown that when it comes to academic achievement, socioeconomic status (SES) is the most determining factor (Hobbs, 1990). Children living in families that are low SES are at-risk for low achievement (O’Hare, 2008). Foster children are more likely to be placed in families that are at-risk, living in poverty, and receiving assistance. The foster family tends to have a householder or spouse that has not graduated high school and is unemployed (O’Hare, 2008).

The Title I program provides funding for programs, materials, professional development, and staffing to help remediate the academic problems associated with being low SES. As shown in Table 2, in West Virginia 55 counties are provided with additional Title I funding. There are 
454 elementary schools in the 55 counties. There are 296 of those elementary schools, or approximately $70 \%$, that are recognized as Title I schools.

\section{Survey Instrument}

For this study the researcher considered the most suitable research method to be a survey. The design of a study is the end result of a series of decisions made by the researcher concerning how the study will be conducted (Coughlan, Cronin, \& Ryan, 2007). Kasunic (2005) indicates that there are many things to consider when developing a survey, including, what does the researcher really want to measure? A critical factor in developing a survey instrument is to translate the researcher's information needs into a set of specific questions that respondents are willing and able to answer (Malhotra, 2004).

Using a survey, the researcher gathered data through a formal, written set of closed-ended questions, in electronic form. The data collected allowed the researcher to describe, compare, or explain knowledge, attitudes, and behaviors. It also allowed the researcher to examine opinions, characteristics, and intentions of the targeted population (Couchman \& Dawson, 1995; Pfleeger \& Kitchenham, 2001).

\section{Eight Elements of Survey Design}

A well-designed survey is important to the success of the research. The aim of a survey design is to get as many responses as possible that are usable and accurate. The development of this survey involved: (1) a research question, (2) literature review, (3) clear instructions, (4) types of questions, (5) general principles for writing questions, (6) question order, (7) layout and sequence, and (8) confidentiality and ethics (Kitcheham \& Pfleeger, 2002; University of Leeds, 2011). The following paragraphs will describe these steps. The survey has a short, meaningful title. Through analysis of the data, the researcher documented the final results. 
(1) Research question. A well-articulated research question defines the focus of the research, its scope and the motivation for the research (Cronon, 2009). It is the research question that sets boundaries that help to navigate where to go next. It "defines which data you need to collect and which methods you will use to access and analyze your documents" (Cronon, 2009, para. 2). According to Danya, International, Inc. (2003) using the following framework helps to develop strong research questions:

- Does the researcher know the field and the literature well?

- Has this study been done before? Is there a large amount of research already conducted on the topic? Is there room for improvement?

- Is there a gap in the research that this study could fill? Could this research lead to a greater understanding?

- Is the timing right for this question to be answered?

- Will this study have a major impact on the field?

(2) Literature review. A thorough understanding of the problem through literature search and readings is important. It is the literature review from Chapter 2 that clarifies an understanding of the topic (Loughborough University, 2011). This researcher notes that a review of literature has indicated that there is a gap in the field of school principals' perceptions of barriers that interfere with the delivery of educational services to foster children.

(3) Clear instructions. To achieve a higher response rate, the researcher provided clear instructions and information. The researcher introduced herself, outlined the purpose of the survey and gave reasons why the responses are important. Clear instructions were provided as to how each question should be answered. Instructions should also indicate how to return the questionnaire and by what date (Loughborough University, 2011). 
(4) Types of questions. There are many types of different questions that could have been used to acquire the information needed. Closed questions elicit quantitative data, are easy for all to respond to, are quick to answer, may improve response rate, and are easy to code and analyze (University of Leeds, 2011). For this research the question type for the survey included questions such as:

- Closed-ended questions: The question is asked and a number of possible answers, such as, yes/no, agree/disagree, true/false, or multiple choice answers, are provided for the respondent (Powell, 1998).

Examples: Have you interacted with a foster child in your school?

- Single response: The respondent is provided with a list of answers and asked to choose the best choice (Powell, 1998).

Example: What does the word "foster care" mean to you? (Circle one number)

1. children picking friends to stay with

2. children who are homeless

3. children living with their parents

4. children staying in an orphanage

- Rated responses: The respondent is asked to indicate their degree of agreement with a statement (Powell, 1998).

Example: Foster children are slow learners

$\begin{array}{llll}\text { Strongly Disagree } & \text { Disagree } & \text { Neither } & \text { Strongly Agree }\end{array}$

(5) General principles for writing questions. Every question should have a purpose. If the researcher cannot clearly identify how the information will be used, the question should not be asked. It is important to keep things simple, concise, and clear (University of Leeds, 2011). For this research the questions: 
- Are concise and unambiguous:

Can the respondent understand the questions (Larossi, 2006)?

Example: How do you work with foster children? This doesn't indicate if the researcher means in the classroom, as a student, academically, personally, etc.

- Avoid double questions: The question should be on one topic only (Larossi, 2006).

Example: Do you understand the role of the school and the welfare system when it comes to working with foster children?

- Avoid involving negatives:

The data from these questions are unreliable because they can be confusing, and the respondent may not be sure how to answer it (Larossi, 2006).

Example: It is not true that you do not feel comfortable working with foster children.

- Ask questions the respondent can answer:

The questions should not be too general or too complex (Larossi, 2006).

- Avoid leading questions:

The respondent shouldn't answer questions a certain way based on the wording or structure of the question (Larossi, 2006).

Example: I assume you agree that teachers do a heroic job for foster children

- Are clearly worded:

The questions are simple, direct, and familiar to the respondents (Larossi, 2006).

(6) Question order. Once the list of questions were developed, the researcher thought 
about the order in which the questions would appear (Loughborough University, 2011). This research considered the following principles:

- Put the most important items in first half of survey

- Start with easy, non-threatening questions, not awkward ones

- Go from general to particular

- Go from factual to abstract

(7) Layout and sequence. The appearance of a survey will encourage or discourage responses (University of Leeds, 2011). The layout and sequence for this research:

- Has a brief introductory statement

- Has contact and return information easily noted and understood

- Has questions and answer choices neatly laid out and displayed

- Includes a range of $25-30$ questions on the questionnaire in order to keep the respondents' interest

- Keeps the flow logical and very simple

- Uses clear headings and numbering when appropriate

(8) Confidentiality and ethics. Using a survey instrument is an easy and quick way to gather information about a large group of people. However, this capability is not to be taken lightly. The researcher cannot conduct a survey irresponsibly and without rigor (Loughborough University, 2011). This researcher:

- Informed respondents of the study's purpose, content, potential risks, and benefits

- Informed respondents that they do not have to answer all the questions

- Informed respondents that they can stop participating in the study at any point

- Kept respondents' identities confidential 
- Assured anonymity

\section{Measures}

Measures involve the process of observing and recording the observations that are collected during research. While there are different categories of measurements, this researcher used a survey and interviews.

Likert scale. The Likert scale is one of the most widely used itemized scales. An itemized rating scale has a number or a brief description associated with each category. The categories are arranged in a logical order, and the respondents are required to select the categories that best describe their reaction to whatever is being rated.

The end points of a Likert scale are typically "strongly disagree" and "strongly agree." The respondents indicate their degree of agreement by checking one of five response categories. The Likert scale is easy for the researcher to construct and administer. It is easy for the respondent to understand. It is suitable for mail, telephone, personal, or electronic interviews (Malhotra, 2004).

Reliability and validity. Reliability and validity are the major criteria used to evaluate the instrument developed for research. Establishing reliability and validity allows the researcher to report with confidence the results obtained from the survey. Suskie (1996) indicated that reliability and validity can be ensured through the use of careful testing procedures and data analysis.

Reliability refers to a test producing consistent results, not necessarily valid results. The instrument must be reliable before it can be considered valid. Reliability is established when the researcher is confident that the process "addresses whether repeated measurements or assessments provide a consistent result given the same initial circumstances" (Handley, 2001, 
para. 1). If a survey is used, will people interpret the questions the same way each time (Rosnow \& Rosenthal, 2008)?

Reliability comes from using a pilot test given to subjects who are not included in the sample. To assess the reliability of the survey for this study, it was appropriate for the researcher to use split-half (Radhakrishna, 2007, para 8). The process of split-half reliability is done by acquiring two sets of scores from the same survey. The idea is to see if the two halves generate the same results. The entire test is given to a group of participants and each participant has two scores - one for each half of the test. The score for each half of those is computed and the splithalf reliability is the extent to which the scores for the first half of the items correlate with the scores of the second half of the items for all of the participants.

Validity is an important criterion for ensuring the quality of a survey instrument (Professional Testing, Inc., 2006). Validity focuses on whether the study has been successful at measuring what the researcher says it is measuring (Rosnow \& Rosenthal, 2008). Validity problems include, but are not limited to, "an inadequate number of items, poor item writing, lack of pilot testing, and lack of item analysis procedures" (Brown, 2000, p.10).

Content validity focuses on the content of the instrument or test (e.g., survey). The content of a measurement procedure will be relevant if it focuses on the specific construct to be measured. To establish content validity, the researcher may select a panel of qualified experts in the content domain to judge the test (Rungtusanatham, 1998).

Because there is no previous instrument, this researcher will be developing something new to gather the data. Validity for this instrument was determined through a panel of experts.

Panel of experts. The use of a panel of experts helps to establish content validity. The panel should consist of experts in the content area of the survey or research design. Each 
question in the questionnaire is given to the panel so that they can rate it. They give their opinion about (1) whether the question survey item is relevant to the study, (2) the clarity of composition of the question, and (3) if the question is essential or useful to the study (Yount, 2006). This research used a panel of experts to help ensure content validity of the survey.

This researcher used a panel of four individuals to review the survey and provide feedback. The first expert was Dr. Lois Weinberg, Associate Professor in the Division of Special Education at California State University, Los Angeles. Dr. Weinberg co-directed the Education Initiative Project in Los Angeles County, which focuses on reducing educational barriers for foster youth. She also directs a project in California which focuses on improving and monitoring educational outcomes for foster children. The second member was Dr. Cheryl Smithgall, a faculty member at Chapin Hall at the University of Chicago. She has chaired many projects that examine the educational issues for children involved with the child welfare system and child welfare placements. The third member of the panel was Dr. James S. Vacca, Associate Professor and Chairman of the Department of Special Education and Literacy at Long Island University, in New York. Dr. Vacca has served as Educational Consultant and Foster Child Advocate for the Department of Social Services in Suffolk County, Long Island. The fourth, and last member of the Panel was Dr. Andrea Zetlin. Dr. Zetlin is a professor in the Division of Special Education and Counseling at CSULA. Dr. Zetlin has worked to develop effective models for schooluniversity-community partnerships to improve educational outcomes for high-risk students. Her most recent project involves working with schools and public agencies to identify and support the educational needs of foster children.

Through email, the panel members were given a brief description of the study and invited to participate. After accepting the invitation, a draft copy of the survey (Appendix A) and 
reviewer instructions (Appendix H) and response form (Appendix I) were sent out. Suggestions from the panel of experts were used to revise the survey before it is sent to the sample group.

The panel will reviewed the survey using the following as guidelines:

- Questions are direct and specific

- Only one question is asked at a time

- Participants can understand what is being asked

- Questions are concise

- There are no ambiguous questions

- The choices listed allow participants to respond appropriately

- The questions are sufficient to address the problem in the study

- The questions are sufficient to answer the research questions

- Are there items that should be deleted? Please indicate if so

- Are there items that should be added? Please indicate if so

Split-half reliability. Split-half reliability is used to determine internal consistency reliability. The process of obtaining split-half reliability is done by splitting in half all of the items that are intended to probe the same area of knowledge in order to form two sets of items. The entire survey is given to a population, the total score for each set is computed, and the splithalf reliability is obtained by determining the correlation between the two total set of scores.

Cronbach's Alpha, a measure of reliability, was used for this research. According to Santos (1990), Cronbach's Alpha is the most dependable statistical measure of internal consistency of survey items used to gauge the survey's reliability. 


\section{Data Collection}

The population for this survey included 296 West Virginia elementary school administrators of Title I Schools. Before invitations were sent to the survey population, an email was sent to county superintendents informing them of the pending research. The notification for the county superintendents is found in Appendix J. All contact information for individuals was gathered from the West Virginia Department of Education site.

The survey was administered via the web. According to Fricker \& Schonlau (2002), internet-based surveys are less expensive to conduct, they are faster, and they yield a higher response rate. A survey instrument developed for this research was administered using West Virginia University College of Education and Human Services Qualtrics Survey Software. Information was given to individuals that included the website address of the online survey and an IRB approved statement that ensured the confidentiality and anonymity for the participants. Appendix $\mathrm{K}$ is the email inviting individuals to participate in the study. After collecting the data, this researcher organized the survey responses and checked for completeness and accuracy.

Dillman (2000) recommends that making several contacts with the participants will increase the response rate for online surveys. The first contact should take place a couple of days before distributing the survey. This contact informed the participant that they would be receiving a survey via email. The second contact involved sending the actual survey to the participant. The third step occurred three days to a week later. This was a quick thank-you to those participants who completed the survey and a reminder to those who did not completed it. The fourth contact occurred two to three weeks after the initial survey was sent out. This was a resending of the survey to those participants who had not responded. Following this guideline data completion was done on December, 3, 2013 (4 weeks). For this study, the survey was 
distributed two days after the superintendent's notice had been sent out. In order to increase the response rate the individuals were invited to participate in the study three times utilizing the email feature of Qualtirics.

Dillman (2000) notes that besides sending the email reminders, offering incentives could also increase the respond rate. Participants were given an opportunity to win one of three $\$ 50.00$ gasoline cards to be awarded upon completing the survey. Two of the cards were awarded to individuals who responded within the first week of the survey. There was a second-chance drawing so that individuals who did not respond the first week had an opportunity to win at the closing of the survey. Dillman (2000) also notes that people who respond like to see the results of the survey. Participants were given the opportunity to receive the results when the study was completed.

The following actions were used to disperse and collect the data:

- The survey was sent to the panel of experts for review.

- After reviewing the survey instrument by the panel of experts and revision as necessary, the West Virginia University Institutional Review Board was contacted for approval to conduct the study.

- A courtesy email to county superintendents was sent telling them about the study.

- The study population was sent an email inviting them to participate in the survey.

- A reminder was sent out a week after the initial survey was sent thanking those who had returned surveys and reminding those who had not.

There was a resending of the survey after two to three weeks to those who had not responded. After four weeks the survey was closed and data analysis began. 


\section{Data Analysis}

The value of the survey would have been lost unless the data were analyzed properly and reported accurately. Data analysis is not about numbers, but instead it uses the numbers to make sense of the research. Analyzing the data allows the researcher to: (1) describe and summarize the data clearly, (2) search for themes and patterns, and (3) answer the research questions (International Program for Development Evaluation Training, 2007).

Question 1: What barriers to principals in West Virginia Title I elementary schools perceive exist for foster children?

The barriers are rated on a scale of (5) Strongly Disagree to (1) Strongly Agree. Responses from the population surveyed were used to calculate a mean score. The Mean ratings of each question were barriers. There is a mean or median to determine items where there are barriers. From this the researcher identified barriers based on how the means were ranked.

Question 2: Is there a relationship between the principals' perception of the barriers as related to the demographics of the participants? The demographics are (2a) years of experience as a principal, (2b) years as principal at that school, (2c) gender, and (2d) region.

The overall research question 2 concerned the relationship in the mean ratings of the Barriers in Educating Foster Children Survey Instrument as related to the demographics of the participants. The demographics are (2a) years of experience as a principal, (2b) years of experience as a principal in that school, (2c) gender, and (2d) region.

The researcher computed correlation coefficients among principals' perception of barriers and demographics. The demographics are (2a) the years of experience as a principal, (2b) years of experience as a principal in that school, (2c) gender, and (d) region of the participant. The independent variable is the years of experience as a principal; years of experience as a principal 
in that school, gender of the participant, and the region (RESA) where the participant works. The dependent variable is the overall survey mean ratings (across the 24 barrier items).

The correlation coefficient is a measure of the strength of association between two variables. It reflects how closely scores on two variables go together. According to Gliner \& Morgan (2000) if the correlation is between 0.0 and 0.30 it is judged to be weak. If it is between 0.31 and 0.70 it is considered to be modest. If it is above 0.71 it is judged to be strong.

Question 3: What experiences have principals in West Virginia Title Elementary schools had with foster children? If participants agreed to be interviewed, the researcher used a uniform constructed interview. The interview was tape recorded and was an attempt to uncover deeper meaning of the experiences and beliefs that principals may have about foster children. Data was collected in textual form through the interview. Probing questions were used to gain more meaning if needed. The researcher anticipated a smaller number of participants agreeing to interview. While there was no set rule, the researcher wanted at least 8 to 12 interviews. From this data, the researcher looked for themes, patterns or phrases that were used. No new volunteers were interviewed when the themes reach data saturation.

Through the use of charts, graphs, and textual write-ups, the researcher presented the calculations and the relationships based on the strengths of the correlations. The results identified the strength of correlations indicating if any relationship exists between the groups in a given independent variable (e.g., gender) for their responses to a dependent variable (e.g., overall survey mean ratings). The researcher attached meaning to the data so that the readers can gain information from the study (Levine \& Roos, 1997).

Documentation. The final stage of the survey process was the preparation and presentation of the survey results. The survey report is the concrete evidence of the research 
project. For this reason was important to carefully consider the content, organization, and clarity of the survey report (Kasunic, 2005). The report communicates effectively the data and recommendations. The documentation is a factual message relying on figures, tables, and graphical displays to clearly communicate the research findings (Kasunic, 2005). The survey results for this research include:

- A narrative background of why the survey was conducted (Chapter 4)

- Presentations that address various aspects of the research work (Chapter 4)

- Complete synthesis of the research questions and the results (Chapter 4)

- Conclusions and recommendations (Chapter 5)

Structured interview. While this research is quantitative in nature, the researcher, or the interviewer, has questions that can best be answered through the interview process. Because of this participants were given the option to mark on the survey if they would participate in an interview with the researcher. Survey questions were developed from the literature researched, as shown in the Matrix of Literature Used (Appendix E).

Research shows that interviewing allows the researcher to gain insight and understanding into the participants' lived experiences from their perceptions (Creswell, 2004). Rossman and Rallis (1998) indicate a researcher uses inquiry to focus on the meaning of a particular experience. Merriman (1998) notes that it is through stories that we make sense of experiences. It is the way that we communicate and understand the world around us. Through dialogue and reflection the researcher gains an understanding of the experience. While Creswell (2004) indicates that purposefully selecting participants will help the researcher understand the problem and the research question, the participants for this research were self-selecting. Since there is limited research that examines the school principals' perceptions of barriers that interfere with 
the educational success of foster children, the interview provided a more complete understanding of the school principals' experiences with foster children.

The interviewer prepared the questions in advance. The interviewer asked all participants the same questions in the same way. The interview questions are found in Appendix C, the Interview Guide. This research used open-ended questions to allow the interviewees options for responding, along with allowing them to voice their experiences and perspectives.

The interview questions were developed using the following criteria: relevance, selection of appropriate respondents, and the ease of answering the questions. Relevance refers to developing questions that are directly related to the purpose of the study. They also have a good probability of yielding the kind of data desired. Selection of respondents needs to be considered. A question may be relevant to the study, but it might not be answerable by the people you are asking. Interview questions need to be fairly easy to answer. Questions also should not cause the interviewee to be embarrassed or cause some sort of a burden (Practical Assessment, Research \& Evaluation, 1997).

During the interview process the role of the interviewer is to explain the procedure, administer the question, listen actively and allow the interviewee time to respond completely without interruption (Creswell, 2004). While the interviewer knows in advance what areas to cover, she is also open and receptive to any unexpected information from the interviewees. Sometimes there is a need for more information when asking a question during an interview. Probing is asking follow-up questions when one does not fully understand the response, if an answer is vague, or when there is a need for more in-depth information. Probing questions are not planned. Probing questions often begin with "what" or "how" which allows the interviewee 
to give more details (Program Development \& Evaluation, 2006). The interviewer will also use a probe, or a comment to elicit explanations about a specific response when needed.

For those volunteers who agreed to an interview, the researcher conducted the interview either in person or by phone. The participants were contacted by telephone numbers provided to the researcher. The participants were informed that the interviews were going to be tape recorded and conducted in private to ensure protection of confidential information.

The role of the researcher is to collect, analyze, and interpret the meaning of the data without bias (Creswell, 2004). The researcher used a semi-structured interview protocol for asking the questions and recording the answers during the interview sessions (Creswell, 2004). The researcher used open-ended questions in search of meaning that reflects the volunteers' perceptions of their interactions and understanding of foster children.

Panel of experts. A draft copy of the interview questions (Appendix D) and reviewer instructions and response form (Appendix G) were sent out. Suggestions from the panel of experts were used to revise the interview questions before being used with a sample group.

The panel reviewed the interview questions using the following as guidelines:

- Questions are ordered in logical and smooth-flowing order

- There are no wording issues that need to be addressed for clarity sake

- Questions are concise

- The questions are sufficient to address the problem in the study

- The questions are sufficient to answer the research questions

- The amount of time to conduct the interview is reasonable

Data analysis. Miles and Huberman (1994) break down the analysis of qualitative data into the following steps: reducing data, displaying data, and drawing and verifying conclusions. 
The following steps were used to analyze and interpret the interview question: (1) organize and prepare the data for analysis, (2) read through all the data, (3) code the data by organizing it into categories or themes, (4) prepare a description of the categories or themes using the coding process, (5) interpret the meaning of the data collected (Creswell, 2004).

\section{Summary}

Chapter Three addresses the research methods that were used to answer the questions about the barriers that school principals in Title I elementary schools perceived interfered with the delivery of educational services to foster children in public schools. The chapter included research design and information about the purpose of the study and the selection of the study population. The chapter included a description of the research procedures including the survey development and the interview development. The chapter also described the manner in which the data are analyzed. 


\section{Chapter 4}

\section{Results}

The purpose of this study was to examine West Virginia Title I elementary school principals' perceptions of barriers that interfere with the delivery of educational services to foster children in public schools. Responses were collected from West Virginia elementary principals who work in Title I schools during November of 2013.

Chapter 4 provides a description and analysis of the data collected from the survey, and from those who volunteered to be interviewed. This chapter includes the return rate and demographic statistics, provides data that addresses the study's research questions, and concludes with a summary of findings.

\section{Return Rate}

The population for this study consisted of 296 West Virginia Title I elementary school principals across the eight RESA regions. Of the 296 principals invited to complete the survey, 127 started the survey, and 121 completed the survey, for overall return rate of 40.8 percent. Survey Monkey (2011) stated that return rates for online surveys average 30\%, and if the survey is administered by email the average return rate is $40 \%$. The survey for this study was an online survey that was initiated by email (Qualtrics).

When there are a large number of non-respondents, it is possible to generalize the survey results. It has been noted that late respondents are often similar to non-respondents (Miller \& Smith, 1983). One method to determine if the results represent an entire population is to compare the data from early respondents to late respondents. If the replies from the early respondents are similar to the replies of late respondents, it can be assumed that the result can be generalized for the population. 
The data comparing these two groups are shown in Table 5. The Table looks at both Years as Principal and Years in Primary Position. However, of the 121 surveys completed only 118 indicted what RESA they represented.

Table 5

Comparison of Demographic Information of Early Respondents and Late Respondents

\begin{tabular}{lccc}
\hline \multicolumn{1}{c}{ Descriptor } & $\begin{array}{c}\text { Early Respondents } \\
(40)\end{array}$ & $\begin{array}{c}\text { Late Respondents } \\
(40)\end{array}$ & $\begin{array}{c}\text { No. Differences between } \\
\text { Early/Late Respondents }\end{array}$ \\
\hline Years as Principal & & & \\
Less than 2-5 & 22 & 13 & 10 \\
$6-10$ & 9 & 19 & 9 \\
$11+$ & 10 & 7 & \\
Years in Primary Position & & & 7 \\
Less than 2-5 & & & 2 \\
$6-10$ & 29 & 30 & 5 \\
$11+$ & 6 & 8 & \\
Gender & 5 & 2 & 9 \\
M & & & 9 \\
F & & & 1 \\
Not Identified & 16 & 7 & \\
\hline
\end{tabular}

The first 40 respondents to the survey were compared to the last 40 respondents to the survey to see if any similarities existed. The first person to complete the survey began at 3:13 a.m. on November 4,2013 . The $40^{\text {th }}$ person began the survey at 10:25 a.m. on November 4 , 2013. The $85^{\text {th }}$ person to complete the survey (the first of the last 40 respondents) began at $4: 43$ p.m. on November 21, 2013.

The early responses to the 24 Barriers were compared to the late respondents to see if they were similar. Because of the similarities in the demographics of early and late respondents 
the data indicated no differences in their perceptions to the 24 Barriers. The data were assumed to represent the entire population. Thus, the results can be generalized to the entire population.

\section{Reliability of the Survey Instrument}

Reliability of the Survey Instrument was determined using Cronbach's Alpha, a measure of inter-item reliability. According to Santos (1990), Cronbach's Alpha is the most dependable statistical measure of internal consistency of survey items used to gauge the survey's reliability. Using the Split-half method to gage the reliability of the test, the researcher split the test items in half (odd/even) in order to form two sets of items. The split-half reliability is obtained by determining the correlation between the two total "set" scores. SPSS software was used to calculate the Cronbach alpha value for this study.

Generally, it has been considered that a Cronbach Alpha of .60 is an indication of strong reliability and that is considered good. A reliability value of .70 is considered high for the social sciences. The Cronbach Alpha value for the survey was .895 , indicating the survey instrument used to gather data for this study was highly reliable.

\section{Demographics}

There were four demographic categories as part of the survey. D1 asked "What are your total years of administrative experience?" D2 asked "What are your total years as administrator in this school?" D3 asked "What is your gender?" D4 asked "Please indicate which RESA you are located in."

Table 6 displays the survey results for D1 and D2. 


\section{Table 6}

Number of Years Respondents Have Served as Administrators and Served in Current School

\begin{tabular}{ccc}
\hline Years & $\begin{array}{c}\text { No. (\%) of } \\
\text { Administrator }\end{array}$ & $\begin{array}{c}\text { No. (\%) of } \\
\text { Administrators in Current School }\end{array}$ \\
\hline $\begin{array}{c}\text { Less than } \\
\text { 6 Years }\end{array}$ & $54(45 \%)$ & $84(70 \%)$ \\
6 -10 years & $38(31 \%)$ & $21(17 \%)$ \\
$\begin{array}{c}\text { More than } \\
\text { 10 Years }\end{array}$ & $31(25 \%)$ & $16(13 \%)$ \\
\hline
\end{tabular}

Most principals (54 or $45 \%$ ) have been administrators less than 6 years. Most principals (84 or $70 \%$ ) have been at their current school for less than 6 years. Few principals (31 or $25 \%$ ) have been in administrator more than 10 years. Few principals (16 or $13 \%)$ have been at their current school more than 10 years. This indicates respondents were a young group of principals and that they changed schools or positions.

D3 asked "Please indicate your gender." Table 7 displays the number of respondents in each of the eight RESA regions for Gender. Two survey respondents did not indicate gender. Table 7 also displays the number of respondents from each RESA region. 


\section{Table 7}

Number \& Percent of Respondents and Gender of Respondents from the RESA Region $(N=119)$

\begin{tabular}{cccc}
\hline RESA & Male & Female & $\begin{array}{c}\text { No. }(\%) \text { of } \\
\text { Respondents }\end{array}$ \\
\hline I & $3(2 \%)$ & $20(16 \%)$ & $23(19 \%)$ \\
III & $3(2 \%)$ & $13(11 \%)$ & $16(14 \%)$ \\
IV & $3(2 \%)$ & $5(4 \%)$ & $8(7 \%)$ \\
V & $3(2 \%)$ & $10(8 \%)$ & $11(9 \%)$ \\
VI & $1(.8 \%)$ & $4(3 \%)$ & $5(10 \%)$ \\
VII & $9(7 \%)$ & $17(14 \%)$ & $27(23 \%)$ \\
VIII & $5(4 \%)$ & $11(9 \%)$ & $16(14 \%)$ \\
Total & $29(25 \%)$ & $89(75 \%)$ & $119(100 \%)$ \\
\hline
\end{tabular}

The largest numbers of respondents were females ( 89 or $75 \%$ ). The most respondents came from RESA I (20 or 16\%). The largest number of respondents from males came from RESA VII (9 or 7\%)). The RESA with the most number of respondents was RESA VII, with 27 $(22.88 \%)$ respondents. The RESA with the least number of respondents was RESA VI, with 5 (4.23\%) respondents. The total number of respondents was 119.

\section{Research Question 1}

What barriers do principals in West Virginia Title I Elementary Schools perceive exist for foster children? The Mean Rating and the Standard Deviation for each of the 24 barriers are shown in Table 8. The barriers are listed in the order of the Mean Ratings with the lowest ratings indicating strongly agree responses to highest ratings indicated strongly disagree responses. 
Each returned survey was entered into a scoring program through Qualtrics that calculated the mean for each barrier. The strongly disagree was assigned the value of 5 , disagree was assigned the value of 4 , neutral was assigned the value of 3 , agree was assigned the value of 2 , and strongly agree was assigned the value of 1 . What this indicates is that the lower the Mean rating, the stronger the agreement among participants. A Mean Rating of 1.0 indicated there was a high level of agreement regarding the barrier.

A low ranking barrier indicates that respondents perceive the barrier to be a strong one that interferes with the delivery of educational services for foster children in their schools. A high ranking barrier indicates that while respondents perceived it was a barrier, it is weaker barrier. 


\section{Table 8}

Mean Ratings and Standard Deviations for Each of the 24 Barriers (Highest to Lowest)

\begin{tabular}{|c|c|c|c|}
\hline $\begin{array}{l}\text { Barrier } \\
\quad \#\end{array}$ & Barrier Question & $\begin{array}{l}\text { Standard } \\
\text { Deviation }\end{array}$ & Mean \\
\hline 6 & $\begin{array}{l}\text { Foster children do not function well academically at any } \\
\text { grade level }\end{array}$ & 0.69 & 1.83 \\
\hline 1 & $\begin{array}{l}\text { Principals are not prepared to meet the learning needs of } \\
\text { foster children }\end{array}$ & 0.97 & 2.06 \\
\hline 9 & $\begin{array}{l}\text { After entry into foster care, children tend to have poor } \\
\text { attendance }\end{array}$ & 0.73 & 2.07 \\
\hline 13 & $\begin{array}{l}\text { Proper school interventions are not implemented for } \\
\text { foster children }\end{array}$ & 0.89 & 2.11 \\
\hline 2 & $\begin{array}{l}\text { Teachers are not prepared to meet the learning needs of } \\
\text { foster children }\end{array}$ & 0.99 & 2.19 \\
\hline 4 & Principals do not know when a child is in foster care & 1.16 & 2.25 \\
\hline 15 & $\begin{array}{l}\text { Foster children are suspended or expelled more often } \\
\text { than their peers }\end{array}$ & 0.72 & 2.32 \\
\hline 3 & $\begin{array}{l}\text { School staff have preconceived ideas about how foster } \\
\text { children learn, behave and achieve }\end{array}$ & 1.06 & 2.34 \\
\hline 5 & $\begin{array}{l}\text { Principals do not understand why a child is placed in } \\
\text { foster care }\end{array}$ & 1.24 & 2.38 \\
\hline 22 & $\begin{array}{l}\text { Foster families don't ensure that foster children do their } \\
\text { homework }\end{array}$ & 0.70 & 2.41 \\
\hline 17 & Foster children have impaired communication skills & 0.89 & 2.55 \\
\hline 24 & $\begin{array}{l}\text { There is a level of mistrust between welfare workers and } \\
\text { school principals }\end{array}$ & 1.07 & 2.55 \\
\hline 7 & $\begin{array}{l}\text { Foster children tend to repeat grade levels more often } \\
\text { than their peers }\end{array}$ & 0.86 & 2.60 \\
\hline 21 & $\begin{array}{l}\text { Foster families don't provide a study space for foster } \\
\text { child(ren) }\end{array}$ & 0.70 & 2.68 \\
\hline 12 & $\begin{array}{l}\text { There is a high percentage of foster children enrolled in } \\
\text { special education }\end{array}$ & 0.75 & 2.74 \\
\hline 11 & $\begin{array}{l}\text { Foster children are under identified for special education } \\
\text { services }\end{array}$ & 0.99 & 2.74 \\
\hline 23 & $\begin{array}{l}\text { Caseworkers don't advocate for the foster child's } \\
\text { educational needs }\end{array}$ & 0.97 & 2.75 \\
\hline 16 & Foster children lack skills to cope with situations & 0.97 & 3.00 \\
\hline 14 & $\begin{array}{l}\text { Behavior of foster children is extreme ranging from } \\
\text { aggressive to passive }\end{array}$ & 1.02 & 3.05 \\
\hline 18 & $\begin{array}{l}\text { Foster children are uncomfortable with others knowing } \\
\text { they are in foster care }\end{array}$ & 0.90 & 3.11 \\
\hline 10 & $\begin{array}{l}\text { Foster children experience frequent school moves that } \\
\text { delay enrollment }\end{array}$ & 1.00 & 3.12 \\
\hline 8 & Foster children do not transfer to new schools with & 1.04 & 3.14 \\
\hline
\end{tabular}


appropriate records

$\begin{array}{llll}20 & \text { There is a lack of support services that address the needs } & 0.90 \quad 3.52\end{array}$ of foster families

19 There is a lack of coordination between child welfare $\quad 0.93 \quad 3.90$ and the school system

The Mean Rating for the 24 Barriers shows that principals perceived the greatest barrier is 6 , with a Mean Rating of 1.83 , which stated "Foster children do not function well academically at any grade level." The weakest ranking barrier indicated by highest Mean Rating is Barrier 19, with a Mean Rating of 3.90, which stated "There is a lack of coordination between child welfare and the school system.”

The Mean for the 24 Barriers is 2.64. Barriers less than 2.64 are perceived to be the greatest barriers interfering with the delivery of educational services to foster children. Standard Deviation (SD) is a measure of the spread of the scores on either side of the mean. The value of standard deviation tells you how spread out the examples in a set are from the mean. The more the scores differ from the mean, the larger the standard deviation will be. SD provides an indication of how much the individual responses to a question vary. When the data in a data set closely match the normal distribution, the standard deviation is small. The lesser the SD, the more stable the item. A small standard deviation indicates not much dispersion. A large standard deviation indicates lots of dispersion.

There were thirteen barriers that fell below the Mean Rating of 2.64. Barriers that fall below the 2.64 Mean rating are as follows:

Barrier 6 states "Foster children do not function well academically at any grade level." This is an In-School Barrier that falls under Academics. Barrier 1 states "Principals are not prepared to meet the learning needs of foster children." This is an In-School Barrier that falls under School Personnel. Barrier 9 states "After entry into foster care, children tend to have poor 
attendance." This is an In-School Barrier that falls under Records. Barrier 13 states "Proper school interventions are not implemented for foster children." This is an In-School Barrier that falls under Special Education. Barrier 2 states "Teachers are not prepared to meet the learning needs of foster children." This is an In-School Barrier that falls under School Personnel. Barrier 4 states "Principals do not know when a child is in foster care." This is an In-School Barrier that falls under School Personnel. Barrier 15 states "Foster children are suspended or expelled more often than their peers." This is an In-School Barrier that falls under Behavior. Barrier 3 states "School staffs have preconceived ideas about how foster children learn, behave and achieve." This is an In-School Barrier and falls under School Personnel. Barrier 5 states "Principals do not understand why a child is placed in foster care." This is an In-School Barrier and falls under School Personnel. Barrier 22 states “Foster families don't ensure that foster children do their homework." This is an Out-of-School Barrier and falls under Foster Families. Barrier 17 states "Foster children have impaired communication skills." This is an In-School Barrier and falls under Social. Barrier 24 states "Foster families do not ensure that foster children do their homework." This is an Out-of School Barrier and falls under Foster families. Barrier 7 states "Foster children tend to repeat grade levels more often than their peers." This is an In-School Barrier and falls under Academics.

Thirteen of the barriers were below the mean rating of 2.64 with eleven of them being InSchool Barriers. Five of those barriers are identified under the category of School Personnel. The other barriers are identified under the category of Academics, Records, Special Education, Behavior, and Social.

Two of the thirteen barriers are Out-of-School Barriers. The category was Foster Families. 


\section{Foster children}

Respondents were asked in survey question \#8 “approximately how many foster children were currently enrolled in your school." The results from the survey question are noted in Table 9.

\section{Table 9}

Number of Foster Children Enrolled in Schools in Each of the Eight RESA Regions

\begin{tabular}{cc}
\hline RESA & Foster Children \\
\hline I & 55 \\
II & 37 \\
III & 5 \\
IV & 27 \\
V & 35 \\
VI & 23 \\
VII & 56 \\
VIII & 42 \\
Total & 280 \\
\hline
\end{tabular}

Table 9 shows the number of foster children that respondents reported are enrolled throughout the schools within each of the eight RESA regions (280). The mean rating for the number of foster children respondents reported enrolled is 35. RESA VII respondents reported the most foster children enrolled (56). RESA III respondents reported the least number of foster children enrolled (5). 
Respondents were given the option of commenting about the number of foster children enrolled in their school. There were a total of 112 respondents who commented. Some reported ranges from 4 to 10 foster children enrolled. One principal reported 10 to 15 foster children per year. One principal reported that the number increases and decreases throughout the school year. Comments included:

- None; I am unaware of any at the current time; I do not know; unknown;

- one I am aware of to date;

- not sure;

- many do not tell us.

Item 9 on the survey asked the respondents "How do you find out that students in your school are part of the foster care system?" Respondents were asked to check all that applied. Table 10 displays the responses from principals in each of the eight RESA regions.

\section{Table 10}

How Principals Find Out That Students in Their School Are Part of Foster Care

\begin{tabular}{lc}
\hline \multicolumn{1}{c}{ Contact } & Response \\
\hline Foster Parent/Legal Guardian & 110 \\
Child Welfare & 46 \\
Family Member/Relative & 36 \\
Student Him/Herself & 32 \\
Counselor & 29 \\
Teacher/Colleague & 27 \\
Cumulative Records/Documentation & 25 \\
Sibling of Foster Child & 14 \\
Friend of Family & 8 \\
Police/Law Enforcement & 5 \\
None of the Above/Never Informed & 0 \\
\hline
\end{tabular}

Table 10 shows that the most frequent way (110) principals find out children are in foster care is from the foster parent or legal guardian. Only 46 principals indicated that the information comes from Child Welfare. There were 32 principals who indicated that the foster child 
informed the principal that he or she was in foster care. The counselor informed 29 principals that a child was in foster care.

Principals were given the opportunity to write in other ways that they are informed of children being in foster care if it was not noted above. Below are the comments that were given:

- We have identified foster care families within attendance area from a student residency form sent home with all students

- Word of mouth

\section{Research Question 2}

Research Question 2 asked if there is a relationship between the principals' perception of the barriers and (2a) years of experience as a principal; (2b) years as principal at that school; (2c) gender; and (2d) region. Pearson Correlation looks for a measure of the correlation that exists between the variables. Correlation describes the relationship that exists between variables. Table 11 outlines the scale used to interpret the strength of the relationship indicted by the correlation coefficient.

Table 11

Relative Strengths of Correlation

\begin{tabular}{cc}
\hline Number Value & Description of Strength \\
\hline .00 to .19 & Very Weak \\
.20 to .39 & Weak \\
.40 to .59 & Moderate \\
.60 to .79 & Strong \\
.80 to 1.0 & Very Strong \\
\hline
\end{tabular}

The strength of the correlation is measured by a correlation coefficient. The coefficient will fall within a range of -1.00 , which is a perfect negative relationship to +1.00 which is a perfect positive relationship. 
Research Question 2a: Is there a relationship between principals' perceptions of the 24 barriers and years of experience as a principal?

$H_{o}$ There is no relationship between the principals'years as an administrator and perceptions of barriers that they perceive exist for foster children.

$H_{a}$ There is a relationship between the principals' years as an administrator and perceptions of barriers that they perceive exist for foster children.

Table 12 displays the results of the relationship between the principals' years as an administrator and perceptions of the 24 barriers. Data were calculated by factor for Pearson $r$ correlation for each question. This calculation is done by using the Mean likert scores for each barrier as indicated for each of the three groups (less than 6 years, 6-10 years, and more than years of administrative experience) and then running a Pearson $r$ in SPSS to get the correlations.

\section{Table 12}

Correlations of Principals' Years of Experience as a Principal and Their Perceptions of the 24 Barriers

\begin{tabular}{|c|c|c|c|c|}
\hline & & $\begin{array}{c}\text { Less Than } 6 \\
\text { Years }\end{array}$ & $\begin{array}{c}6-10 \\
\text { Years } \\
\end{array}$ & $\begin{array}{c}\text { More than } 10 \\
\text { Years }\end{array}$ \\
\hline $\begin{array}{c}\text { Less than } 6 \\
\text { Years }\end{array}$ & Pearson $r$ & 1.00 & $.956 * *$ & $.942 * *$ \\
\hline $6-10$ Years & Pearson $r$ & $.956 * *$ & 1.00 & $.960 * *$ \\
\hline $\begin{array}{c}\text { More Than } \\
10 \text { Years }\end{array}$ & Pearson $r$ & $.942 * *$ & $.960 * *$ & 1.00 \\
\hline
\end{tabular}

**Correlation is significant at the 0.01 level (2-tailed).

The correlation between principals with less than 6 years of experience and principals with 6-10 years of experience is .956 . That is a high positive relationship between these two groups and significant for (2 tailed), which is significant at the .01 level. 
The correlation between principals with less than 6 years of experience and principals with more than 10 years of experience is .942 . That is a high positive relationship between these two groups and significant for (2-tailed), which is significant at the .01 level.

The correlation between principals with more than 6-10 years of experience and principals with more than 10 years of experience is .960 . That is a positive relationship between these two groups and significant for (2-tailed), which is significant at the .01 level.

Every correlation shows a high positive relationship and the .01 level is strong indicating that these relationships exist. Anything below .05 is significant. SPSS reports the p-value for this test as being .01 which indicates that there is strong evidence to believe $H_{a}$, thus rejecting the Null Hypothesis. Therefore, the three groups' perceptions of barriers are not different. There is a relationship between the principals' perceptions of the 24 barriers and the years of experience as a principal.

Research Question 2b: Is there a relationship between the principals' perception of barriers and years as principal at that school?

$H_{o}$ There is no relationship between the principals' years as an administrator in their current school and the perception of barriers that they perceive exist for foster children $H_{a}$ There is a relationship between the principals' years as an administrator in their current school and the perception of barriers that they perceive exist for foster children

Table 13 displays results about the relationship between principals' years as an administrator in their current school and their perceptions of the 24 barriers. Data were calculated by factor for Pearson $r$ correlation using means per each question. 


\section{Table 13}

Correlations of Principals' Years as Principal at that School and Their Perceptions of the 24 Barriers

\begin{tabular}{ccccc}
\hline & & $\begin{array}{c}\text { Less Than } 6 \\
\text { Years }\end{array}$ & $\begin{array}{c}6-10 \\
\text { Years }\end{array}$ & $\begin{array}{c}\text { More Than } 10 \\
\text { Years }\end{array}$ \\
\hline $\begin{array}{c}\text { Less than } 6 \\
\text { Years }\end{array}$ & Pearson $r$ & 1.00 & $.925^{* *}$ & $.921^{* *}$ \\
$6-10$ Years & Pearson $r$ & $.925^{* *}$ & 1.00 & $.872^{* *}$ \\
$\begin{array}{c}\text { More Than } \\
\text { 10 Years }\end{array}$ & Pearson $r$ & $.921^{* *}$ & $.872^{* *}$ & 1.00 \\
& & & & \\
\hline
\end{tabular}

**Correlation is significant at the 0.01 level (2-tailed)

The correlation between principals with less than 6 years of experience and principals with 6-10 years of experience is .925 . That is a high positive relationship between these two groups and significant for (2 tailed), which is significant at the 0.01 level.

The correlation between principals with less than 6 years of experience and principals with more than 10 years of experience is .921 . That is a high positive relationship between these two groups and significant for (2-tailed), which is significant at the 0.01 level.

The correlation between principals with 6-10 years of experience and principals with more than 10 years of experience is .872. That is a positive relationship between these two groups and significant for (2-tailed), which is significant at the 0.01 level.

Every correlation shows a high positive relationship and the 0.01 level is strong that these relationships exist. Anything below .05 is significant. SPSS reports the p-value for this test as being 0.01 which indicates that there is strong evidence to believe $H_{a}$, thus rejecting the Null Hypothesis. Therefore, the three groups' perceptions of barriers are not different. There is a relationship between the principals' perceptions of the 24 barriers and years as principal at that school. 
Research Question 2c: Is there a relationship between the principals' gender and their perceptions of the 24 barriers?

$H_{o}$ There is no relationship between the principals' gender and the perception of barriers that they perceive exist for foster children

$H_{a}$ There is a relationship between the principals' gender and the perception of barriers that they perceive exist for foster children

Table 14 shows the relationship between the principals' gender and their perceptions of the 24 barriers.

\section{Table 14}

Correlations of Principals' Gender and Their Perceptions of the 24 Barriers

\begin{tabular}{cccc}
\hline & & Female & Male \\
\hline Female & Pearson $r$ & 1.00 & $.934 * *$ \\
Male & Pearson $r$ & $.934 * *$ & 1.00 \\
\hline$* *$ Correlation
\end{tabular}

**Correlation is significant at the 0.01 level

The correlation between female and male is .934 . That is a high positive relationship between these two groups and significant for (2-tailed), which is significant at the 0.01 level. Therefore, the two groups' perceptions of barriers are not different. SPSS reports the p-value for this test as being 0.01 which indicates that there is strong evidence to believe $H_{a}$, thus rejecting the Null Hypothesis. There is a relationship between principals' gender and their perceptions of the 24 barriers. They see the barriers in the same way.

Research Question 2d: Is there a relationship between the principals' perception of the barriers and RESA region?

$H_{o}$ There is no relationship between the principals' RESA Region and the perception of barriers that they perceive exist for foster children 
$H_{a}$ There is a relationship between the principals' RESA Region and the perception of barriers that they perceive exist for foster children

Table 15 shows the relationship between the principals' RESA region and their perceptions of the 24 barriers.

\section{Table 15}

Correlations of Principals' RESA Region and Their Perceptions of the 24 Barriers

\begin{tabular}{|c|c|c|c|c|c|c|c|c|c|}
\hline & & $\begin{array}{c}\text { RESA } \\
\text { I }\end{array}$ & $\begin{array}{c}\text { RESA } \\
\text { II }\end{array}$ & $\begin{array}{c}\text { RESA } \\
\text { III }\end{array}$ & $\begin{array}{c}\text { RESA } \\
\text { IV }\end{array}$ & $\begin{array}{c}\text { RESA } \\
\mathrm{V}\end{array}$ & $\begin{array}{c}\text { RESA } \\
\text { VI }\end{array}$ & $\begin{array}{c}\text { RESA } \\
\text { VII }\end{array}$ & $\begin{array}{c}\text { RESA } \\
\text { VIII }\end{array}$ \\
\hline $\begin{array}{c}\text { RESA } \\
\text { I }\end{array}$ & Pearson $r$ & 1.00 & $.819 * *$ & $.736 * *$ & $.790 * *$ & $.856 * *$ & $.689 * *$ & $.896 * *$ & $.909 * *$ \\
\hline $\begin{array}{c}\text { RESA } \\
\text { II }\end{array}$ & Pearson $r$ & $.819 * *$ & 1.00 & $.766^{* *}$ & $.721 * *$ & $.866^{* *}$ & $.633 * *$ & $.865 * *$ & $.906 * *$ \\
\hline $\begin{array}{c}\text { RESA } \\
\text { III }\end{array}$ & Pearson $r$ & $.736 * *$ & $.766 * *$ & 1.00 & $.689 * *$ & $.799 * *$ & $.637 * *$ & $.844 * *$ & $.823 * *$ \\
\hline $\begin{array}{c}\text { RESA } \\
\text { IV }\end{array}$ & Pearson $r$ & $.790 * *$ & $.721 * *$ & $.689 * *$ & 1.00 & $.787 * *$ & $.702 * *$ & $.788 * *$ & $.851 * *$ \\
\hline $\begin{array}{c}\text { RESA } \\
\mathrm{V}\end{array}$ & Pearson $r$ & $.856 * *$ & $.866 * *$ & $.799 * *$ & $.787 * *$ & 1.00 & $.765^{* *}$ & $.831 * *$ & $.943 * *$ \\
\hline $\begin{array}{c}\text { RESA } \\
\text { VI }\end{array}$ & Pearson $r$ & $.689 * *$ & $.633 * *$ & $.637 * *$ & $.702 * *$ & $.765^{* *}$ & 1.00 & $.660 * *$ & $.791 * *$ \\
\hline $\begin{array}{c}\text { RESA } \\
\text { VII }\end{array}$ & Pearson $r$ & $.896 * *$ & $.865 * *$ & $.844 * *$ & $.788 * *$ & $.831 * *$ & $.660 * *$ & 1.00 & $.936 * *$ \\
\hline $\begin{array}{c}\text { RESA } \\
\text { VIII }\end{array}$ & Pearson $r$ & $.909 * *$ & $.906 * *$ & $.823 * *$ & $.851 * *$ & $.943 * *$ & $.791 * *$ & $.936 * *$ & 1.00 \\
\hline
\end{tabular}

The correlation between:

- $\quad$ RESA I and RESA II is .819;

- $\quad$ RESA I and RESA III is .736;

- $\quad$ RESA I and RESA IV is .790; 
- RESA I and RESA V is .856;

- RESA 1 and RESA VI is .689;

- RESA I and RESA VII is .896; and

- RESA I and RESA VIII is .909.

Which is a high positive relationship between RESA I and the seven other RESA regions and significant for (2 tailed), which is significant at the 0.01 level.

The correlation between:

- $\quad$ RESA II and RESA I is .819;

- $\quad$ RESA II and RESA III is .766;

- $\quad$ RESA II and RESA IV is .721;

- RESA II and RESA V is .866;

- RESA II and RESA VI is .633;

- $\quad$ RESA II and RESA VII is .865; and

- $\quad$ RESA II and RESA VIII is .906 .

Which is a high positive relationship between RESA I and the seven other RESA regions and significant for ( 2 tailed), which is significant at the 0.01 level.

The correlation between:

- RESA III and RESA I is .736;

- $\quad$ RESA III and RESA II is .766;

- RESA III and RESA IV is .689;

- RESA III and RESA V is .799;

- $\quad$ RESA III and RESA VI is .637;

- RESA III and RESA VII is .844; and 
- $\quad$ RESA III and RESA VIII is .823.

Which is a high positive relationship between RESA III and the seven other RESA regions and significant for (2 tailed), which is significant at the 0.01 level.

The correlation between:

- RESA IV and RESA I is .790;

- $\quad$ RESA IV and RESA II is .721;

- $\quad$ RESA IV and RESA III is .689;

- RESA IV and RESA V is .787;

- $\quad$ RESA IV and RESA VI is .702;

- RESA IV and RESA VII is .788; and

- $\quad$ RESA IV and RESA VIII is .851.

Which is a high positive relationship between RESA IV and the seven other RESA regions and significant for (2 tailed), which is significant at the 0.01 level.

The correlation between:

- RESA V and RESA I is .856;

- $\quad$ RESA V and RESA II is .866;

- $\quad$ RESA V and RESA III is .799;

- RESA V and RESA IV is .787;

- RESA V and RESA VI is .765;

- RESA V and RESA VII is .831; and

- RESA V and RESA VIII is .943.

Which is a high positive relationship between RESA V and the seven other RESA regions and significant for (2 tailed), which is significant at the 0.01 level. 
The correlation between:

- $\quad$ RESA VI and RESA I is .689;

- $\quad$ RESA VI and RESA II is .633;

- $\quad$ RESA VI and RESA III is .637;

- $\quad$ RESA VI and RESA IV is .702;

- $\quad$ RESA VI and RESA V is .765;

- RESA VI and RESA VII is .660; and

- $\quad$ RESA VI and RESA VIII is .791.

Which is a high positive relationship between RESA III and the seven other RESA regions and significant for ( 2 tailed), which is significant at the 0.01 level.

The correlation between:

- $\quad$ RESA VII and RESA I is .896;

- $\quad$ RESA VII and RESA II is .865;

- $\quad$ RESA VII and RESA III is .844;

- $\quad$ RESA VII and RESA IV is .788;

- $\quad$ RESA VII and RESA V is .831;

- RESA VII and RESA VI is .660; and

- $\quad$ RESA VII and RESA VIII is .936.

Which is a high positive relationship between RESA VII and the seven other RESA regions and significant for (2 tailed), which is significant at the 0.01 level.

The correlation between:

- $\quad$ RESA VIII and RESA I is .909;

- RESA VIII and RESA II is .906; 
- $\quad$ RESA VIII and RESA III is .823;

- RESA VIII and RESA IV is .851;

- $\quad$ RESAVIII and RESA V is .943;

- $\quad$ RESA VIII and RESA VI is .791; and

- $\quad$ RESA VIII and RESA VII is .936.

Which is a high positive relationship between RESA VIII and the seven other RESA regions and significant for (2 tailed), which is significant at the 0.01 level. SPSS reports the pvalue for this test as being 0.01 which indicates that there is strong evidence to believe $H_{a}$, thus rejecting the Null Hypothesis. There is a relationship between the principals' perception of the 24 barriers and RESA region.

\section{The Interview}

The purpose of collecting qualitative data was to better understand what experiences West Virginia Title I elementary principals have had with foster children. The interview process in this study allowed the researcher to gain insight into the research question posed by the study. Research question (3) asked, "What experiences have principals in West Virginia Title I schools had with foster children?" The researcher conducted individual interviews with respondents who volunteered to be interviewed in the final question of the interview.

\section{Participants}

The interview population consisted of West Virginia Title I elementary school principals who volunteered to be interviewed. Respondents indicated on the survey if they would like to be interviewed and supplied contact information. Of the 35 who volunteered to be interviewed, 16 provided contact information. The following narrative presents the themes from the 12 interviewed. 
The participants were contacted by telephone numbers provided to the researcher. The participants were informed that the interviews were going to be tape recorded. To protect the privacy of the participants and the confidential nature of the information, no demographics were identified and participants were identified only as respondent 1 , respondent 2 . Interviews lasted between fifteen to twenty-five minutes. All participants answered each of the 12 questions regarding their personal experiences with foster children. Several of the participants answered question 13 by saying there was nothing else they wanted to share.

The interviews served as the means of data collection from the participant's viewpoint. The researcher served as the interviewer and supplied the questions. The interview questions consisted of 13 structured questions and 14 probing questions, (Appendix D \& Appendix E) which focused on the participants' experiences with foster children.

All participants received the identical set of questions, allowing them to expand their responses as appropriate. All of the participants' responses were audio taped to ensure confidentiality and data analysis. Interviews lasted between fifteen to twenty-five minutes. All participants answered each of the 12 questions regarding their personal experiences with foster children. Several of the participants answered question 13 by saying that there was nothing else they wanted to share.

Though the responses were qualitative, a coding system was developed that allowed for data aggregation and analysis. At the conclusion of the interviews, the recorded conversations were transcribed verbatim.

There were a total of twelve interviews conducted. There were seven males and five females. 


\section{Themes}

Many principals that were interviewed expressed their concern about foster children moving in and out so much and a concern over the foster placement itself. Respondent number 12, an elementary Title I school principal indicated that he has had several foster children that come through his school. While he felt that it was rewarding for him to be involved with the foster child, he didn't think that foster care has been real rewarding for the child.

He noted that many foster kids came to him with gaps because they have been out of school for so long. What bothered him the most was that they didn't get the chance to stay in his school very long. Some came and stay a few days, some a few weeks, and some a few months. They would just get into a routine in his school and then they were moved on. It bothered him that they didn't stay long in the school or in the foster home. He noted that it was a fragmented relationship that developed. It bothered him that sometimes the foster children were moved into a different foster home or back in with the biological parents, only to be moved again. One of the frustrating things that bothered him was that he was never sure if it was the government agency, the foster parents or the biological parents that weren't cooperating.

He felt that while the foster homes provided the physical needs for the foster child, he didn't feel that the emotional needs of the children were always being met. Because of this he saw how the foster child suffered socially from the lack of emotional needs being met, those needs only real parents can provide.

Respondent number 9 indicated that as a principal in the school system she saw foster kids coming in and going out of her school. Her concern was that the foster system has people who are foster parents that should not have children in their home or in their care. She felt that it was a private industry for them, not a safe haven for the foster children. She indicated that one 
of the problems was that the foster parents get the kids, keep them for a short time and then the child is moved on somewhere else. The principal felt that it was frustrating cycle because by the time their records and information reach the school, the child was gone.

There were five major themes that surfaced from the interviewing process. These themes include (1) academic barriers, (2) special challenges, (3) frustrations, (4) experiences with agencies, and (5) strategies or interventions when working with foster children.

\section{Academic Barriers}

From the interviews the following academic barriers emerged: children come with no background knowledge, attendance, continuity, reading deficits, gaps or holes in learning, lack interventions that most kids get, lack vocabulary, low reading comprehension, and struggle with reading and math.

Interview question 3 asked participants to describe the academic barriers that they felt foster children struggled with in school. The topic of academic barriers was discussed many times throughout the interview session, not just during question 3:

- “most foster children struggle because they don't have a background. Because of neglect they haven't been taught." (Respondent 2)

- "Them going to school is a big thing. Coming to school is a major step in the right place. Many are behind academically because many have not gone to school very much.” (Respondent 12)

- "foster children struggle with continuity in my school. You get pulled out of school and sent here and sent there and so forth and so on-continuity is a problem.” (Respondent 4, 7, 8, 9) 
- "Reading is something that you need to do outside of school. Practicing all the time. If you are coming from an unstable home life you have not don't that."(Respondent 5, 10)

- 'they don't have the interventions that most of the kids that have been here for a while have had. They don't have the vocabulary." (Respondent 9)

- "barriers are similar to low SES. " (Respondent 6)

- "because of the transient nature of their lives they struggle with reading and math mostly. Gaps in reading and math ability." (Respondent $11,5,12$ )

\section{Special Challenges}

Another theme to emerge was special challenges that foster children in school faced. While there was a long list, the most important and frequently mentioned challenges included: emotional issues, behavior issues, they aren't with their biological parents, adapting to other students, social challenges, students are fragile, issues that we know nothing about, and we aren't prepared to deal with foster children.

- "Special challenges...I guess adapting to the other students. And if they are special education students that takes even a little more training and work on our part.” (Respondent 3)

- "Many times there are behavior issues. They may come with behavioral plans or we have to write behavioral plans." (Respondent 5)

- "I think one challenge is sometimes they want to be with their real parents and they get real upset and stuff when they can't see them. That's one challenge. And getting them to understand it's better for them." (Respondent 6) 
- "The biggest problem — not so much with the school, but what they are dealing with at home or what they aren't dealing with at home. Most have issues because they have been removed and are not with their biological parents. A lot of emotional issues you deal with before you can even get to the academics.” (Respondent 2, 3, 4, 5)

\section{Frustrations}

The third theme was what frustrated school principals the most when working with foster children. The responses dealt more with outside school barriers rather than inside school barriers. These included: frustrating to work with the system, lack of communication, foster parents don't spend the time they should with foster child, lack of cooperation with agencies, lack of information about the child's educational needs, lack of information about what the child has been through, and emotional needs of the foster child aren't being met.

- "The system is what is frustrating to work with. Communication is frustrating.” (Respondent 7,3 )

- "Two things frustrate me-sometimes foster parents don't want to spend the time. They want the money. The second part is we don't get a lot of cooperation from the state or whoever has custody of these kids."

(Respondent 2)

- 'I know the people working with them are getting paid—but I don't see the money being spent on them." (Respondent 3)

- "The lack of information of what they are coming to us with or without in terms of education and in terms of emotional baggage. Or even the types of things they've been through.” (Respondent 5) 
- "foster homes provide the physical needs for the foster child, but they don't meet the emotional needs" (Respondent 12)

\section{Experiences with Agencies}

This was a theme that emerged through many of the responses to the interview questions. While there were a few positive responses, most were negative in nature. These included: no communication with agencies, nobody checks with the school, unrealistic expectations of the school, frustrating to deal with, and no pleasant experiences working with social services.

- “Most part -doesn't seem like they touch base with us like they should. I think they should check with us and see how the child is doing in school. I think they sometimes are too quick to take the word of the foster parent." (Respondent 2)

- "Zero experience—never seen one. In the last two years not seen anybody. Just knowing why they are here would help.” (Respondent 3)

- "I think they have unrealistic expectations about what the school should provide for the child." (Respondent 5)

- “Lack of communication. They don't follow up with me. I don't have a lot of pleasant experiences working with social services.” (Respondent 7)

- "It's frustrating at times. I've called DHHR and just let them have it. They need to take some of these parents off their list of foster homes. It's frustrating. You may deal with one person one time and then never again. You get a good one and they are gone. It's a huge turn over in the office." (Respondent 11)

- "I haven't had good experiences with Child Welfare" (Respondent 12) 


\section{Strategies or Interventions When Working with Foster Children}

The respondents all had strategies and interventions that they had used that were successful in their schools. These strategies included: involving the foster child in school programs and activities, recognize issues and deal with them, make sure foster children are included, keep in mind foster children may not be able to appropriately or effectively express themselves, be open minded, be patient, listen to them, pair the foster child up with a peer buddy, monitor them closely, work with the foster parents, and involve everyone that works with them.

- "involve them as much as you possibly can in school programs and activities. Make them feel welcome.” (Respondent 1)

- "Recognize issues and deal with them on case to case bases." (Respondent 2)

- “Just listening to him." (Respondent 3)

- "Help foster kids and all kids feel included, fit in and be successful." (Respondent 4)

- "Realize that you are working with a child who probably has not had experiences in terms of how people appropriately and effectively express themselves. Express their emotions, their frustrations, and their anger. In terms of what generally wouldn't trigger a child who has not grown up in the foster system could trigger a foster child.” (Respondent 5)

- "Be open minded." (Respondent 6)

- "Being patient, by not trying to do too much at one time, giving time to selfreflect.” (Respondent 7) 
- "I would pair them up with someone, to make sure that you touch base with them on a daily bases in some way and to stay in close contact with foster parents and teachers about progress.” (Respondent 8)

- "Monitor, monitor, monitor. Keep an eye on them. They are in a fragile state when they get to us." (Respondent 9)

- "Just working with the parents. Help them meet the needs of the child." (Respondent 10)

- "Be patient with them. We try to involve everyone at the school that works with them. Even our cooks and custodians keep an on them." (Respondent 11)

\section{Summary of Findings}

This study sought to determine West Virginia Title I elementary school principals’ perceptions of barriers that interfere with the delivery of educational services for foster children. The study also sought to determine if there was a relationship between the principals' perception of barriers and their years of experience as a principal, years as principal at current school, gender, and RESA region.

- The RESA with the most respondents to the survey was RESA VII $(n=27)$.

- The largest group of respondents had less than 6 years administrative experience $(n=54)$.

- The largest group of respondents had been at their current school less than 6 years $(n=84)$.

- $\quad$ The largest group of respondents were females $(n=89)$.

1. What barriers do principals in West Virginia Title I elementary schools perceive exist for foster children? The Median for the Mean rating of the 24 barriers is 2.64. Anything below 2.64 is a barrier of high agreement among the respondents. The lesser the $\mathrm{SD}$, the more stable the 
variation. There were thirteen barriers of high agreement, with eleven of them in the category of In-School Barriers. Five of the barriers were in the factor category of School Personnel, two barriers were in the factor category of Academics, one barrier was in the factor category of Behavior, one barrier in the factor category of Records, one barrier was in the factor category of Social, and one barrier was in the factor category of Special Education.

- Academics: Barrier \#6 which states, "Foster children do not function well academically at any grade level”. (Mean Rating 1.83, SD .69)

- School Personnel: Barrier \#1 which states, "Principals are not prepared to meet the learning needs of foster children”. (Mean Rating 2.06, SD .97)

- Records: Barrier \#9 which states, "After entry into foster care, children tend to have poor attendance". (Mean Rating 2.07, SD .73)

- Special Education: Barrier \#13 which states, "Proper school interventions are not implemented for foster children”. (Mean Rating 2.11, SD .89)

- School Personnel: Barrier \#2 which states, "Teachers are not prepared to meet the learning needs of foster children”. (Mean Rating 2.19, SD .99)

- School Personnel: Barrier \#4 which states, "Principals do not know when a child is in foster care". (Mean Rating 2.25, SD 1.16)

- Behavior: Barrier \#15 which states, "Foster children are suspended or expelled more often than their peers". (Mean Rating 2.3, SD .72)

- School Personnel: Barrier \#3 which states, "Staff have preconceived ideas about how foster children learn, behave and achieve". (Mean Rating 2.34, SD 1.06)

- School Personnel: Barrier \#5 which states, "Principals do not understand why a child is placed in foster care". (Mean Rating 2.38, SD 1.24) 
- Social: Barrier \#17 which states, "Foster children have impaired communication skills". (Mean Rating 2.55, SD 0.89)

- Academics: Barrier \#7 which states, "Foster children tend to repeat grade levels more often than their peers". (Mean Rating 2.60, SD 0.86)

2. Is there a relationship between the principals' perception of the barriers and (2a) years of experience as a principal; (2b) years as principal at that school; (2c) gender; and (2d) RESA region?

- A relationship existed between the perceptions of principals with Less than 6 years as a principal, 6-10 years as a principal, and more than 10 years as a principal and the 24 barriers.

- A relationship existed between the perceptions of principals with less than 6 years at their current school, 6-10 years at their current school, and more than 10 years at their current school and the 24 barriers.

- A relationship existed between perceptions of principals and female gender and the 24 barriers.

- A relationship existed between perceptions of principals and male gender and the 24 barriers.

- A relationship existed between perceptions of principals in RESA I, II, III, IV, V, VI, VII, and VIII and the 24 barriers. 


\section{Null Hypothesis}

The Null Hypotheses was rejected in this study. A high positive relationship between demographics and the principals' perceptions of the 24 barriers was measured by Pearson $r$.

The data indicate that the demographics all see the 24 barriers in the same way, they rated them consistently. There were no differences no matter the principals' years as an administrator, how long they were at one location, gender, or RESA region.

This chapter summarized the collected data from the transcriptions of interviews. The participants provide insight about their experiences with foster children in their schools, a topic for which there is little information. The five themes that emerged from the interviews included: academic barriers, special challenges, frustrations, experiences with agencies, and strategies or interventions when working with foster children. 


\section{Chapter 5}

\section{Conclusions, Discussions, and Recommendations}

This chapter includes a summary, study conclusions, discussion, insights, and recommendations for policy, practice, and research, and researcher's insights. This chapter provides an overview of the data with conclusions drawn from the data pertaining to the research questions presented in Chapter four.

\section{Introduction}

Research notes that there has been much written about the foster child's dilemma in schools, but not about what principals perceive to be their barriers in school. The purpose of this study was to determine if school principals in West Virginia Title I elementary school perceived that there were barriers that interfere with foster children succeeding academically. According to Fletcher-Campbell (1997) the need to identify a successful model for addressing the educational needs of foster children has not yet been explored. Findings from this study have potential to contribute to the field of educational leadership related to the perceived barriers and the academic success of foster children in West Virginia.

Principals at West Virginia Title I elementary schools were invited to respond to an online survey instrument. The survey was developed on Qualtrics and designed specifically for this study by the researcher. The survey, through research, identified 24 possible barriers that could interfere with the delivery of educational services to foster children. The participants were asked to indicate to what extent they agreed the items were barriers that interfered with meeting the educational needs of foster children in their school. A 5 point Likert scale was used to see if the participate strongly disagreed to strongly agreed that item was a barrier. There were four 
variables that were demographics. Demographics included the administrative years of experience, years as an administrator at the current school, gender, and RESA region,

The population for this study consisted of 296 West Virginia Title I elementary school principals, but 118 responded. Each of these principals received a letter introducing the researcher, study, a brief overview of the instrument, and a request to participate (See Appendix L).

\section{Conclusions}

The study contained three research questions. Selected findings follow each:

Research Question 1: What barriers do principals in West Virginia Title I Elementary Schools perceive exist for foster children?

There was a high level of agreement about which barrier interfered with the academic success of foster children in school. West Virginia Title I elementary school principals indicated Barrier 6, which stated "Foster children do not function well academically at any grade level." Thus, the research demonstrated agreement among the West Virginia Title I elementary school principals the In-School Barrier, Barrier 6, stated "Foster children do not function well academically at any grade level," was the highest ranking barrier. West Virginia Title I elementary school principals perceive this barrier interferes with the delivery of educational services for foster children in their schools.

There was a high level of agreement that Barrier 1, 6, 9, 13, 2, 4, 15, 3, 5, 22, 17, 24, and 7 interfered with the academic success of foster children in school. Eleven of the thirteen barriers $(1,6,9,13,2,4,15,3,5,17$, and 7) are barriers that fall under the category of In-School barriers. Five of those barriers are under the heading of school personnel. Two of the barriers are under the heading of Academics. One is under the heading of records, one is under the 
heading of special education, one is under the heading of Social, and one is under the heading of behavior.

Research Question 2: Is there a relationship between the principals' perception of barriers and the demographics of the participants? The demographics were (2a) years of experience as a principal, (2b) years as principal at that school, (2c) gender, and (d) region.

D2a: Results of correlations completed using Pearson $r$ showed there was a high positive relationship of the three groups (Less than 6 years, 6-10 years, and more than 10 years) perceptions of the 24 barriers. The .01 level strongly indicates that a relationship exists. This finding rejects the null hypothesis.

D2b: Results of correlations completed using Pearson $r$ showed there was a high positive relationship of the three groups' (less than 6 years, 6-10 years and more than 10 years) perceptions of the 24 barriers. The .01 level strongly indicates that a relationship exists. This finding rejects the null hypothesis.

D2c: Results of correlations completed using Pearson $r$ showed there was a high positive relationship between these two groups' (male and female) perceptions of the 24 barriers. The .01 level strongly indicates that a relationship exists. This finding rejects the null hypothesis.

D2d: Results of correlation completed using Pearson $r$ showed there was a high positive relationship between the eight RESA regions perceptions of the 24 barriers. The .01 level strongly indicates that a relationship exists. This finding rejects the null hypothesis.

Research Question 3: What experiences have principals in West Virginia Title I elementary schools had with foster children? Five themes emerged from the data collected through the interviews. Those themes included Academic Barriers, Special Challenges, 
Frustrations, Experiences with Agencies, and Strategies or Interventions When Working with Foster Children.

The theme of Academic Barriers indicated that respondents noted foster children have:

- gaps in their knowledge base,

- they struggle with continuity,

- poor attendance,

- deficiencies in reading and math, and

- they have barriers that are similar to low SES students.

The theme of Special Challenges indicated that respondents felt that foster children did have to cope with special challenges. Frequently mentioned challenges included:

- emotional issues,

- they weren't with their biological parents,

- adapting to other students,

- social challenges,

- they come to the schools in a fragile state, and

- issues that we know nothing about.

The theme of Frustrations indicated that respondents did have frustrations when dealing with foster children, but the frustrations were not always with the child, but at times with the processes and the agencies involved. Frustrations included:

- frustrating to work with the system,

- lack of communication,

- foster parents don't spend the time they should with foster child,

- lack of cooperation with agencies, 
- lack of information about the child's educational needs,

- lack of informational about what the child has been through, and

- emotional needs of the foster child aren't being met.

The theme of Experiences with Agencies indicated that a few respondents had good experiences with the agencies; most respondents do not have any working relationships with the agencies that are involved with the foster children.

The theme of Strategies or Interventions when Working with Foster Children indicates that respondents:

- work hard to make the school experience a positive one for the foster children, no matter the length of time they are in their school.

- $\quad$ keep the child involved, and

- monitor what was going on with the child.

\section{Discussion}

The Non-participators. A number (175) of principals that were requested to participate in the online survey choose not to participate. To gain participation the researcher contacted each principal by letter online and a follow-up reminder indicating the date the survey would be open. A number of reasons might explain the lack of willingness to participate in the survey, which could include, time restraints, time of the year, and not knowing the topic to be surveyed.

The research took place during month of November, which tends to be a busy time of the school year for administrators. It is a month that has holidays throughout the time period, which means administrators may have been out of their office. There are also various meetings and functions that school administrators are obligated to attend. 
This was also a sensitive topic that may have intimidated some administrators. They may have felt that they were not knowledgeable enough about the topic to participate in the survey. They may have felt that there could be improper use or misinterpretation of the survey data, even though the researcher stated that this would not be the case. Principals may have thought the survey would somehow target their school or the foster children in their school.

Principals are held to a high standard of confidentiality when it comes to protecting children. While the research was conducted to provide insight and help to the principals, they may not have trusted an outsider with such private information. The lack of participation could also have been due to the fact that the school principal did not feel knowledgeable enough about the topic to participate in the survey.

Some administrators sent back responses that they did not have foster children in their school at that time. They may have thought that they had to have foster children present to participate in the survey.

Foster children do not function well in school at any age. West Virginia Elementary Title I principals' ranked Barrier 6 as the highest, which research cited in the Literature Review of the present document supports. For example, Avery (2001), Christian (2003), Pears, Fisher, \& Bronz (2007), all indicate that foster children do not function well in school at any age. They also note that they are academically at-risk for school failure. Altshuler (1997) indicates foster children struggle with success in school and that a large percentage of foster children will experience school failure. Zetlin (2006) indicates that research shows 30\% of foster children perform below level and 50\% are held back a grade level in school. Frerer, Sosenko, Pellegrin, Zakharenkov, Horowitz, and Patton (2011) notes that not only do foster children fall behind the general student population, they also fall behind the other at-risk student population. Zetlin, 
Weinberg, \& Kimm (2003) indicate that foster children are more likely to be retained a grade level due to academic gaps.

There is a lack of coordination between child welfare and the school system. West Virginia Elementary Title I principals ranked Barrier 19 as the lowest. Research indicates that there is a lack of cooperation between social workers and educators and there is also a level of mistrust between these agencies due to a difference in perceptions (Conger \& Finkelstein, 2003; Stone, et.al, 2007). The biggest challenge that research indicated for these agencies is that they do not coordinate their efforts or share information about the children in their systems. In order for the educational needs of the children to be met, Vera Institute notes that the systems (child welfare, education and the courts) must work together with a focus on the education of the foster child.

Numbers of foster children reported. Item 8 on the survey asked for principals “approximately how many foster children are currently at your school?” The respondents indicated a total of 280 foster children enrolled in the various schools.

According to the State Child Welfare Policy Database, (2007), there were 4,409 children in West Virginia in foster care at the end of 2007. According to database, $853(19.3 \%)$ of the children were between 2 and 5 years of age, and 1,047 (23.7\%) of the children were between 6 and 12 years of age. This would include students in grades Preschool and Kindergarten through $4^{\text {th }}$ grade, which is the elementary setting for West Virginia schools. This is a total of 1,900 children in foster care in West Virginia. That amounts to approximately 1,620 foster children not accounted for in the school system.

There could be various reasons for the discrepancy in numbers. The first logical reason for the large difference could be the fact that there was a very low response rate to the survey. 
Out of 296 school principals contacted only 119 responded. The other reasons could be, school principals may not be aware that a child in their school is in foster care, foster children may not be enrolled in schools, and foster children could be in between schools and not on any school roster.

Survey respondents identified barriers that fell in the category of In-School Barriers. Four out of the eight barriers $(50 \%)$ were in the factor category of School Personnel. Participants who were interviewed indicated that they have concerns about the educational gaps that foster children have. They also indicated their frustration at not having a working relationship with the agencies involved with the foster children.

The education system and the child welfare system are both guided by the common mission to serve the best interests of children. A collaborative, working relationship needs to be established with the school system and the agencies involved with foster children in order for there to be a seamless educational process for the these children. The school system and the welfare system need to ensure that the educational needs of the foster children are met.

\section{Survey respondents indicated the needs of foster children are the same as low SES}

children. According to research done by Barrat and Berliner (2013) "the message that students in foster care constitute a distinct subgroup of at-risk students has not yet been clearly or fully translated from research to policy to practice" (p. 2). The study also indicates "students in foster care have unique characteristics that justify their identification as a separate at-risk student subgroup, and that this subgroup has a significant achievement gap compared to other student groups" (p. 3). It also noted that foster children have a different demographic profile when compared to their low SES peers. Just doing the same for foster children as we do for low SES students is not going to help close the achievement gap for foster children. 
Principals' understanding of a caring leadership role. Research has noted there is a link between caring and learning. Because the foster child comes from an environment that tends to be unstable and lacking a caring, nurturing environment, the role of the school principal is significant for both the foster child and the school personnel. Noddings (1992) noted that care is "an operation of deep concern that carries us out of ourselves and into the lives, despairs, struggles, and hopes of other" (p. 5). The school principal should feel "obligated to do what is required to maintain and embrace caring" (p. 94).

School administrators should have training and support to become the caring administrators who will meet the diverse needs of the students in their schools, and not the needs of the organization. The role of a caring principal is to meet the needs of all students and to help transform schools into caring communities. The focus in schools tends to be on the test scores and not on the well-being of children. Caring Leadership needs to be explored and implemented in the school setting.

\section{Recommendations for Practice}

The information collected in this study provides a point of reference for adults who work with foster children in schools. The results of this study can give school principals an enhanced perspective. The adults who share the responsibility for children in foster care need to work together to provide opportunities for educational success for these children.

Adults who have the responsibility of placing, moving and monitoring children in foster care should be aware of the educational impact they have when administering these changes.

There needs to be professional development and workshops for school principals that focus on the barriers that interfere with delivery of educational services to foster children. 
Gaining an understanding of the barriers that foster children face daily could help school principals improve the educational opportunities for children who are in foster care.

The following are recommendations based on conclusions:

1. Provide orientation programs to help school principals develop an environment for foster children.

- Caring Leadership

- Understanding the Foster Child

2. Develop district guidelines to guide the school principal in addressing the educational needs of foster children.

- Administrators in both child welfare and education work collaboratively to create systemic change through a commitment to joint planning and goal setting.

- Research interventions that increase academic achievement of foster children

- Identify training in supports associated with improving academic outcomes for foster children.

- Develop strategies that focus on communication between child welfare and the school system.

3. Improve coordination and cooperation between child welfare agencies and schools

- Use electronic information databases to communicate

- Hire liaisons to ensure increased communication between the agencies \& schools

- Implement cross-training programs for school personnel, foster parents and child welfare department 
The identified barriers of greatest concern and the themes that emerged from the interviews need to be addressed. Table 16 displays the identified barriers and themes under categories of interventions to address the issues.

\section{Table 16}

Interventions to Address the Identified Barriers and Themes

\begin{tabular}{lll}
\hline \multicolumn{1}{c}{ Orientation Programs } & \multicolumn{1}{c}{ District Guidelines } & \multicolumn{1}{c}{$\begin{array}{c}\text { Coordination/Cooperation } \\
\text { Between Agencies }\end{array}$} \\
\hline $\begin{array}{l}\text { Address the academics needs } \\
\text { of foster child }\end{array}$ & $\begin{array}{l}\text { Provide guidance on how } \\
\text { principals will know when a child } \\
\text { is in foster care }\end{array}$ & $\begin{array}{l}\text { Improve collaboration and } \\
\text { communication through } \\
\text { partnerships }\end{array}$ \\
$\begin{array}{l}\text { Address differences of low } \\
\text { SES vs. at-risk foster child }\end{array}$ & $\begin{array}{l}\text { Address suspension or expulsion } \\
\text { of foster child }\end{array}$ & $\begin{array}{l}\text { Interagency trainings } \\
\text { Address the needs principals } \\
\text { have about working with } \\
\text { foster children }\end{array}$ \\
$\begin{array}{l}\text { Address preconceived ideas } \\
\text { about foster child }\end{array}$ & $\begin{array}{l}\text { Address attendance for foster } \\
\text { child }\end{array}$ & \\
$\begin{array}{l}\text { Address special challenges of } \\
\text { working with foster child }\end{array}$ & & \\
\hline
\end{tabular}

\section{Future Research}

Timing is very important when trying to collect data from school principals. In the future I would arrange for my contact time to be at the end of September or the beginning of October. These are less stressful time periods and I believe more principals would take time to review and respond to a survey.

Identifying a general problem area to research was challenging, but setting up the approach and designing an experiment was difficult. I explored several ways to gather my data and would still use the same approaches. Developing the survey was a challenging task. While I feel that the instrument provided me with good data, I may have been able to structure it better if 
I had examined other surveys that had been used for data collection. I may have been able to structure my instrument to gather the data with fewer items for the participants to have to answer. I also would add an item that allowed for the participant to respond with comments.

The interviewing process was one that provided me with a greater understanding of how the participants viewed the research topic. This tool was valuable in gathering data but it was a very time consuming process. The participants were very responsive; however, as I got towards the end of the questioning it seemed that they answered quickly and were ready to end the process. In order to keep the interest, I would develop an interview guide with a more precise focus and less questions for the participants.

Given the low number in participants, additional research exploring the School Principals' Perceptions of the Barriers that Interfere with the Delivery of Educational Services for Foster Children is needed. Because little research has been conducted to explore this area, to improve the delivery of educational services to this at-risk population, additional research should be conducted.

Due to the fact that results from the survey indicated no differences, future research could be conducted using a different set of demographics, such as, surveying elementary principals in non-Title I schools, Central Office personnel and administrators. It is possible that the perceptions would be different based on other demographics. 
APPENDIX A

Survey Instrument 


\section{Barriers in Educating Foster Children Survey Instrument}

To what extent do you agree that the following are barriers that interfere with meeting the needs of foster children in your school?

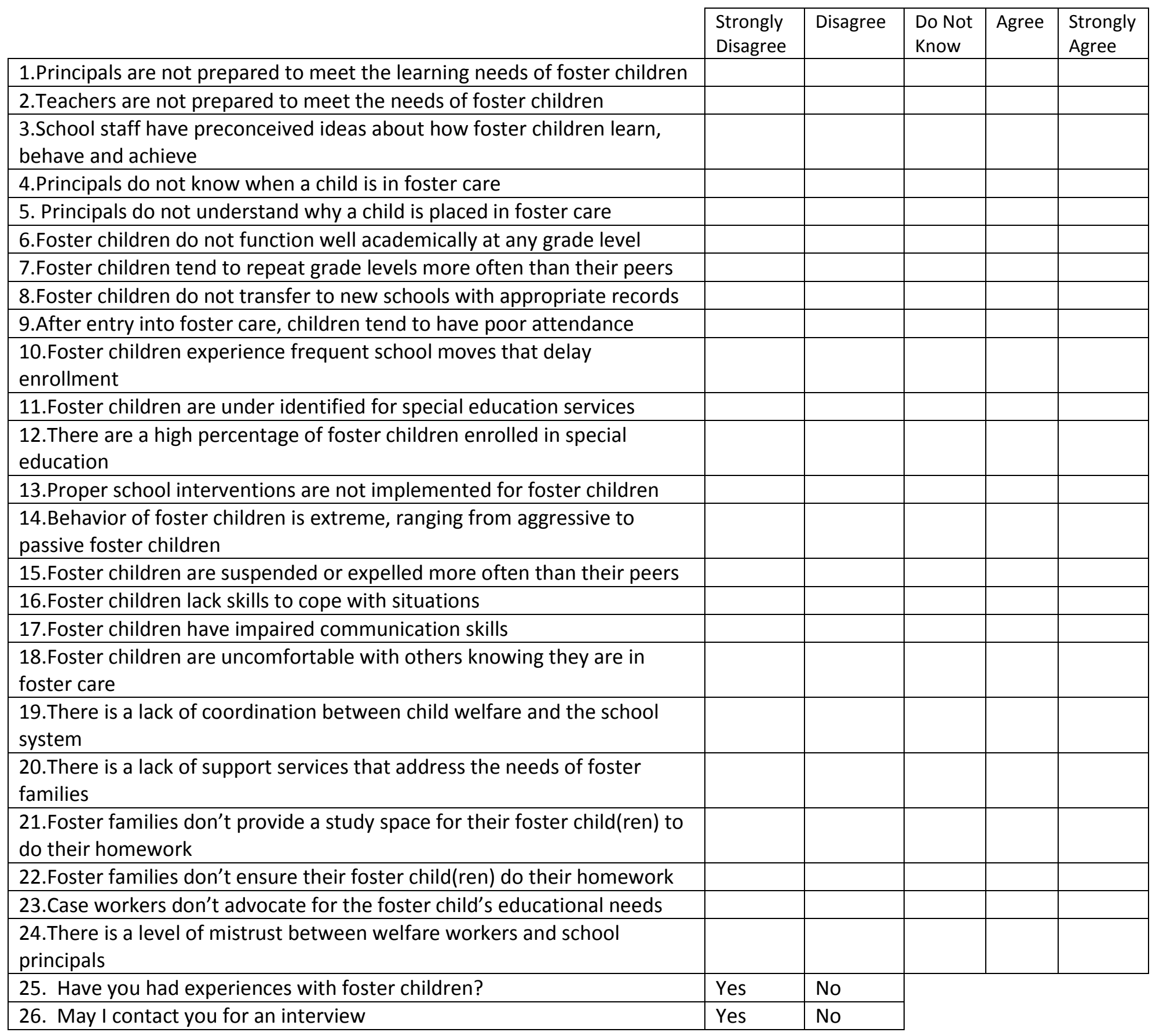


D1. What are your total years of administrative experiences?

O less than 2 years

○ 2-5 years

○ 6-10 years

o 11-15 years

o 16-20 years

- More than 20 years (please indicate the length of time )

D2. What are your total years as administrator in this school?

O Less than 2 years

○ 2-5 years

○ 6-10 years

○ 11-15 years

○ $16-20$ years

- More than 20 years (please indicate the length of time

D3. My gender is:

o Male

o Female

How do you find out that children in your school are part of the foster care system? (Check all that apply)

- Family member or relative

O Foster parent/legal guardian

O Friend of the family

o Cumulative record or documentation

o Student him/herself

○ Child welfare

○ Police/law enforcement

o Teacher/colleague

- Sibling of foster child

o Counselor

O None of the above-never informed

o Other

Approximately how many foster children are currently at your school?

May I contact you for interviewed?

○ Yes If yes, please give me your name and contact information (email, phone number, etc.)

$\circ$ No 
APPENDIX B

Matrix Displaying the Relationship between the Literature and the Survey Items 
Matrix Displaying the Relationship between the Literature and the Survey Items

$\underline{\text { Demographics }}$

\begin{tabular}{|l|l|l|l|}
\hline $\begin{array}{c}\text { Factor } \\
\text { Category }\end{array}$ & \multicolumn{1}{|c|}{ Points In Literature } & \multicolumn{1}{|c|}{ Reference } & \multicolumn{1}{|c|}{ Survey Item } \\
\hline $\begin{array}{l}\text { School } \\
\text { Principal } \\
\text { teaching experience }\end{array}$ & $\begin{array}{l}\text { Over 99\% of principals have } \\
\text { Most public school principals have } \\
\text { an average of 14 years teaching } \\
\text { experience }\end{array}$ & Hine, 2003 & $\begin{array}{l}\text { D1: How many years of } \\
\text { teaching experience have } \\
\text { you had? }\end{array}$ \\
\hline $\begin{array}{l}\text { Women tend to be dominate as } \\
\text { elementary principal, men } \\
\text { secondary }\end{array}$ & $\begin{array}{l}\text { Rand Corporation, n.d. } \\
\text { Drincipals lack awareness, How many years of } \\
\text { expectations, educational strategies, } \\
\text { and exposure to fully understand } \\
\text { the foster child's plight }\end{array}$ & $\begin{array}{l}\text { Reaching Every Child, } \\
\text { you had? }\end{array}$ & $\begin{array}{l}\text { D6: My gender is: } \\
\text { Q1: Principals are not } \\
\text { prepared to meet the } \\
\text { learning needs of foster } \\
\text { children }\end{array}$ \\
\hline
\end{tabular}

In School Barriers

\begin{tabular}{|c|c|c|c|}
\hline $\begin{array}{c}\text { Factor } \\
\text { Category }\end{array}$ & Points in Literature & Reference & Survey Item \\
\hline \multirow[t]{4}{*}{$\begin{array}{l}\text { School } \\
\text { Personnel }\end{array}$} & $\begin{array}{l}\text { Not prepared to teach foster } \\
\text { children }\end{array}$ & $\begin{array}{l}\text { Cormier, } 1994 \\
\text { Vacca, } 2004\end{array}$ & $\begin{array}{l}\text { Q2: Teachers are not } \\
\text { prepared to meet the } \\
\text { learning needs of foster } \\
\text { children. }\end{array}$ \\
\hline & $\begin{array}{l}\text { Preconceived ideas about foster } \\
\text { children }\end{array}$ & Powers \& Stotland, 2002 & $\begin{array}{l}\text { Q3: School staffs have } \\
\text { preconceived ideas about } \\
\text { how foster children learn, } \\
\text { behave and achieve. }\end{array}$ \\
\hline & $\begin{array}{l}\text { School principals are unaware of } \\
\text { the presence of foster children in } \\
\text { their schools }\end{array}$ & Palladino, 2006 & $\begin{array}{l}\text { Q4: Principals do not } \\
\text { know when a child is in } \\
\text { foster care. }\end{array}$ \\
\hline & $\begin{array}{l}\text { Don't understand history of foster } \\
\text { children }\end{array}$ & Gustavsson, 1991 & $\begin{array}{l}\text { Q5: Principals do not } \\
\text { understand why a child is } \\
\text { placed in foster care. }\end{array}$ \\
\hline \multirow[t]{2}{*}{ Academics } & $\begin{array}{l}\text { Foster children do not function } \\
\text { well at any grade level }\end{array}$ & $\begin{array}{l}\text { Avery, } 2001 \\
\text { Christian, } 2003 \\
\text { Pears, Fisher, \& Bronz, } \\
2007\end{array}$ & $\begin{array}{l}\text { Q6: Foster children do } \\
\text { not function well } \\
\text { academically at any grade } \\
\text { level. }\end{array}$ \\
\hline & $\begin{array}{l}\text { Many foster children end up } \\
\text { repeating grades }\end{array}$ & $\begin{array}{l}\text { Atshuler, } 2003 \\
\text { Emerson \& Lovitt, } 2003 \\
\text { Jacobson, } 2008 \\
\text { Paulson, } 2005\end{array}$ & $\begin{array}{l}\text { Q7: Foster children tend } \\
\text { to repeat grade levels } \\
\text { more often than their } \\
\text { peers. }\end{array}$ \\
\hline
\end{tabular}




\begin{tabular}{|c|c|c|c|}
\hline Records & $\begin{array}{l}\text { Schools don't have adequate } \\
\text { information about foster children }\end{array}$ & $\begin{array}{l}\text { Finkelstein, } 2002 \\
\text { Gustavsson, } 1991\end{array}$ & $\begin{array}{l}\text { Q8: Foster children do } \\
\text { not transfer to new } \\
\text { schools with appropriate } \\
\text { records. }\end{array}$ \\
\hline & $\begin{array}{l}\text { Foster children have poor } \\
\text { attendance }\end{array}$ & $\begin{array}{l}\text { National Center for } \\
\text { Mental Health } \\
\text { Promotion \& Youth } \\
\text { Violence Prevention, } \\
2010\end{array}$ & $\begin{array}{l}\text { Q9: After entry into } \\
\text { foster care, foster children } \\
\text { tend to have poor } \\
\text { attendance. }\end{array}$ \\
\hline & $\begin{array}{l}\text { Frequent moves at the beginning } \\
\text { of year and during year delay } \\
\text { enrollment in school }\end{array}$ & $\begin{array}{l}\text { Weinberg, Zetlin, \& } \\
\text { Shea, } 2006\end{array}$ & $\begin{array}{l}\text { Q10: Foster children } \\
\text { experience frequent } \\
\text { school moves that delay } \\
\text { enrollment. }\end{array}$ \\
\hline $\begin{array}{l}\text { Special } \\
\text { Education }\end{array}$ & $\begin{array}{l}\text { Under identified for special } \\
\text { education services } \\
\text { High percentage of foster children } \\
\text { in special education }\end{array}$ & $\begin{array}{l}\text { Vesecky, Woodard, \& } \\
\text { Levine, } 2005 \\
\text { Lips, } 2007 \\
\text { Reynolds, } 2011\end{array}$ & $\begin{array}{l}\text { Q11: Foster children are } \\
\text { under identified for } \\
\text { special education services } \\
\text { Q12: There are a high } \\
\text { percentage of foster } \\
\text { children enrolled in } \\
\text { special education. }\end{array}$ \\
\hline & $\begin{array}{l}\text { Proper interventions not } \\
\text { implemented for foster children }\end{array}$ & $\begin{array}{l}\text { Christian, } 2004 \\
\text { Jacobson, } 2008 \\
\text { Runyan \& Gould, } 1985\end{array}$ & $\begin{array}{l}\text { Q13: Proper school } \\
\text { interventions are not } \\
\text { implemented for foster } \\
\text { children }\end{array}$ \\
\hline Behavior & $\begin{array}{l}\text { Behavior is extreme aggressive to } \\
\text { passive }\end{array}$ & $\begin{array}{l}\text { Avery, } 2001 \\
\text { Christian, } 2004 \\
\text { Conger \& Finkelstein, } \\
2003 \\
\text { Atshuler, } 1997 \\
\text { Pears, Fisher \& Bronz, } \\
2007 \\
\text { Vacca, } 2004\end{array}$ & $\begin{array}{l}\text { Q15: Behavior of foster } \\
\text { children is extreme, } \\
\text { ranging from aggressive } \\
\text { to passive. }\end{array}$ \\
\hline & $\begin{array}{l}\text { Foster children are suspended or } \\
\text { expelled more often than peers }\end{array}$ & $\begin{array}{l}\text { Smithgall, Gladde, } \\
\text { Yang, \& George, } 2005\end{array}$ & $\begin{array}{l}\text { Q15: Foster children are } \\
\text { suspended or expelled } \\
\text { more often than their } \\
\text { peers. }\end{array}$ \\
\hline Social & $\begin{array}{l}\text { Foster children lack skills to cope } \\
\text { with situations }\end{array}$ & $\begin{array}{l}\text { Costin \& Rapp, } 1984 \\
\text { Vacca, 2004 } \\
\text { Gustavsson, } 1991\end{array}$ & $\begin{array}{l}\text { Q16: Foster children lack } \\
\text { skills to cope with } \\
\text { situations }\end{array}$ \\
\hline & Impaired communication skills & $\begin{array}{l}\text { Glastone, } 1981 \\
\text { Green, } 1978 \\
\text { Kinard, } 1982\end{array}$ & $\begin{array}{l}\text { Q17: Foster children } \\
\text { have impaired } \\
\text { communication skills. }\end{array}$ \\
\hline & $\begin{array}{l}\text { Foster children struggle with the } \\
\text { "foster care" status }\end{array}$ & Gustavsson, 1991 & $\begin{array}{l}\text { Q18: Foster children are } \\
\text { uncomfortable with } \\
\text { others knowing they are } \\
\text { in foster care. }\end{array}$ \\
\hline
\end{tabular}


Out of School Barriers

\begin{tabular}{|l|l|l|l|}
\hline $\begin{array}{c}\text { Factor } \\
\text { Category }\end{array}$ & \multicolumn{1}{|c|}{ Points in Literature } & \multicolumn{1}{c|}{ Reference } & \multicolumn{1}{c|}{ Survey Item } \\
\hline $\begin{array}{l}\text { Child } \\
\text { Welfare } \\
\text { System }\end{array}$ & $\begin{array}{l}\text { Lack of cooperation between } \\
\text { social workers \& educators }\end{array}$ & $\begin{array}{l}\text { Conger \& Finkelstein, } \\
2003 \\
\text { Stone, et., al, 2007 }\end{array}$ & $\begin{array}{l}\text { Q19: There is a lack of } \\
\text { coordination between } \\
\text { child welfare \& the } \\
\text { school system. }\end{array}$ \\
\hline $\begin{array}{l}\text { Lack of support services that } \\
\text { address the needs of foster families }\end{array}$ & Jacobson, 2008 & $\begin{array}{l}\text { Q20: There is a lack of } \\
\text { support services that } \\
\text { address the needs of } \\
\text { foster families. }\end{array}$ \\
\hline & $\begin{array}{l}\text { Caseworker does advocate for the } \\
\text { foster child's educational needs }\end{array}$ & Vera Institute, 1999-2002 & $\begin{array}{l}\text { Q23: Case workers } \\
\text { don't advocate for the } \\
\text { foster child's } \\
\text { educational needs. }\end{array}$ \\
\hline $\begin{array}{l}\text { Foster } \\
\text { Families }\end{array}$ & $\begin{array}{l}\text { There is a level of mistrust } \\
\text { diffeen both agencies due to }\end{array}$ & $\begin{array}{l}\text { Conger \& Finkelstein, } \\
\text { 2003 in perceptions }\end{array}$ & $\begin{array}{l}\text { Q24: There is a level of } \\
\text { mistrust between welfare } \\
\text { workers and the school } \\
\text { principal }\end{array}$ \\
\hline & $\begin{array}{l}\text { Foster parents don't provide } \\
\text { structured environment for foster } \\
\text { child to study }\end{array}$ & Finkelstein, et.al, 2002 & $\begin{array}{l}\text { Q21: Foster families } \\
\text { don't provide a study } \\
\text { space for their foster } \\
\text { child(ren) to do } \\
\text { homework }\end{array}$ \\
\hline $\begin{array}{l}\text { Foster families worry more about } \\
\text { the child's behavior and not about } \\
\text { education }\end{array}$ & Finkelstein, Wamsley \& & $\begin{array}{l}\text { Q22: Foster families } \\
\text { don't ensure their foster } \\
\text { child(ren) do their } \\
\text { homework }\end{array}$ \\
\hline
\end{tabular}




\section{Appendix C}

Introduction and Closing for Interview 


\section{Introduction}

Hello, my name is Jane DeVaul, a doctoral student at West Virginia University. My research is explores barriers in educating foster children. I will be taping this conversation for datarecording accuracy purposes, but your comments will be held confidential. I will not identify participants specifically with anything they say during the interview. The information will be used only in aggregate when compiling and documenting the research findings.

\section{Closing}

Thank you for participating in this interview. If you are interested in the results of my research, you can give me your address and I would be happy to share the final results with you. 
Appendix D

Interview Guide 
Interview Guide

Telephone Interview

Tape Recorded

Principal's Name:

Date of Interview:

School:

1. Tell me about your experiences with foster children.

2. How many foster children do you have in your school this year? What grades are they in?

3. Describe the academic barriers that you feel foster children struggle with in your school.

4. Describe any special challenges that foster children in your school face.

5. Tell me how you make sure foster children are succeeding academically.

6. What kinds of difficulties do foster children experience in your school?

7. Describe the behavioral problems foster children display.

8. What do you think are the unique needs of foster children compared to their non-foster peers?

9. Describe the interactions between foster children in your school and the non-foster children?

10. Explain how you involve the foster child's foster family in the school environment.

11. What has been your experience in dealing with the school social worker, child welfare or other agencies on behalf of the foster children in your school?

12. What strategies or interventions would you recommend when working with foster children?

13. Is there anything that we haven't discussed that you would like to share? 
Appendix E

Probing Questions 


\section{Probing Questions for the Interview Session}

1b. Explain what you like most about working with foster children?

1c. What successes have you had with foster children?

1d. Describe what frustrates you most when working with foster children?

2b. Explain to me how you become aware of your students' foster care status.

3b. How do your address these problems?

4b. What kinds of strategies are in place to address these challenges?

4c. Describe the process involved in working with foster children to correct the problems?

6b. Tell me what strategies are in place to address these problems?

7b. How do you address these problems?

7c. What has worked well?

7d. Who works with the foster children when there are behavioral problems?

$8 \mathrm{~b}$. What services are available in your school to address these unique needs of foster children?

9b. What concerns do you have about these interactions?

11b. What would make this interaction more successful for you? 


\section{Appendix F}

Matrix Displaying the Relationship between the Literature and the Interview Questions 
Matrix Displaying the Relationship Between the Literature and the Interview Questions

\begin{tabular}{|c|c|c|}
\hline $\begin{array}{l}\text { Points In Literature } \\
\text { School administrators } \\
\text { have preconceived } \\
\text { ideas about foster } \\
\text { children. }\end{array}$ & \begin{tabular}{l}
\multicolumn{1}{c}{ Reference } \\
Cormier, 1994 \\
Vacca, 2004
\end{tabular} & 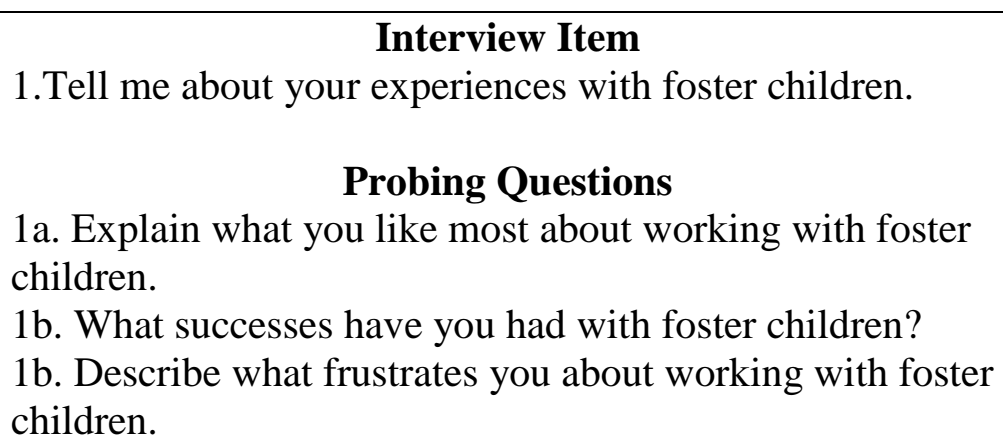 \\
\hline $\begin{array}{l}\text { School administrators } \\
\text { are unaware of the } \\
\text { presence of foster } \\
\text { children in their } \\
\text { school. }\end{array}$ & $\begin{array}{l}\text { Palladino, } \\
2006 \\
\text { Reaching } \\
\text { Every Child, } \\
2005\end{array}$ & $\begin{array}{l}\text { 2. How many foster children do you have in your school } \\
\text { this year? What grades are they in? } \\
\text { Probing Question } \\
\text { 2a. Explain to me how you become aware of your students' } \\
\text { foster care status. }\end{array}$ \\
\hline $\begin{array}{l}\text { Not much has been } \\
\text { done in examining } \\
\text { the academic barriers } \\
\text { facing foster children }\end{array}$ & Ferguson, 1999 & $\begin{array}{l}\text { 3.Describe the academic barriers that you feel foster } \\
\text { children struggle with in your school. } \\
\text { Probing Question } \\
\text { 3a. How do you address these problems? }\end{array}$ \\
\hline $\begin{array}{l}\text { Foster children face } \\
\text { unique challenges } \\
\text { and obstacles }\end{array}$ & $\begin{array}{l}\text { Frerer, } \\
\text { Sosenko, } \\
\text { Pellegrin, } \\
\text { Zakharenkov, } \\
\text { Horowitz, \& } \\
\text { Patton, } 2011\end{array}$ & $\begin{array}{l}\text { 4. Describe any special challenges that foster children in } \\
\text { your school face. } \\
\text { Probing Question } \\
\text { 4a. What kinds of strategies are in place to address these } \\
\text { 4b. Describe the process involved in working with foster } \\
\text { children to correct the problems }\end{array}$ \\
\hline $\begin{array}{l}\text { Foster children are at } \\
\text { a tremendous risk } \\
\text { educationally }\end{array}$ & $\begin{array}{l}\text { Zetlin } \\
\text { Weinberg, \& } \\
\text { Kimm, } 2003 \\
\text { Joftus, } 2007 \\
\text { Stone, } 2007 \\
\text { Gustavsson \& } \\
\text { MacEachron, } \\
2001\end{array}$ & $\begin{array}{l}\text { 5. Tell me how you make sure foster children are } \\
\text { succeeding academically? }\end{array}$ \\
\hline $\begin{array}{l}\text { Foster children do not } \\
\text { function well in } \\
\text { school at any age. }\end{array}$ & $\begin{array}{l}\text { Avery, } 2001 \\
\text { Christian, } 2003 \\
\text { Pears, Fisher, } \\
\text { \& Bronz, } 2007\end{array}$ & $\begin{array}{l}\text { 6. What kinds of difficulties do foster children experience } \\
\text { in your school? } \\
\text { Probing Question } \\
\text { 6a. What strategies are in place to address these problems? }\end{array}$ \\
\hline $\begin{array}{l}\text { Foster children } \\
\text { develop behavioral, }\end{array}$ & $\begin{array}{l}\text { Avery, } 2001 \\
\text { Christian, } 2004\end{array}$ & $\begin{array}{l}\text { 7. Describe the behavioral problems foster children } \\
\text { display. }\end{array}$ \\
\hline
\end{tabular}




\begin{tabular}{|c|c|c|}
\hline $\begin{array}{l}\text { physical, and } \\
\text { emotional disorders } \\
\text { that they bring to the } \\
\text { classroom }\end{array}$ & $\begin{array}{l}\text { Conger \& } \\
\text { Finkelstein, } \\
2003\end{array}$ & $\begin{array}{l}\text { Probing Question } \\
\text { 7a. How do you address these problems? } \\
\text { 7b. Has it worked well? } \\
\text { 7c. What has worked well? }\end{array}$ \\
\hline $\begin{array}{l}\text { School } \\
\text { Administrators have } \\
\text { little or no training to } \\
\text { work with foster } \\
\text { children; } \\
\text { School } \\
\text { Administrators lack } \\
\text { knowledge of how to } \\
\text { meet the challenges } \\
\text { of the foster child's } \\
\text { many needs }\end{array}$ & $\begin{array}{l}\text { Hanson, } 2009 \\
\text { Comier, } 1994 \\
\text { Ellermann, } \\
2007 \\
\text { Emerson \& } \\
\text { Lovitt, } 2003 \\
\text { Finkelstein, et. } \\
\text { al, 2002 } \\
\text { Schwarts, } 1999\end{array}$ & $\begin{array}{l}\text { 8. What do you think are the unique needs of foster } \\
\text { children compared to their non-foster peers? } \\
\text { Probing Question } \\
\text { 8a. What services are available in your school to address } \\
\text { these unique needs of foster children? }\end{array}$ \\
\hline $\begin{array}{l}\text { One major aspect that } \\
\text { is missing from the } \\
\text { foster child's life is } \\
\text { that sense of } \\
\text { belonging }\end{array}$ & $\begin{array}{l}\text { Reynolds, } \\
2011\end{array}$ & $\begin{array}{l}\text { 9. Describe the interactions between foster children in your } \\
\text { school and the non-foster children. } \\
\text { Probing Question } \\
\text { 9a. What concerns do you have about these interactions? }\end{array}$ \\
\hline $\begin{array}{l}\text { Educators blame } \\
\text { foster families for the } \\
\text { difficulties that foster } \\
\text { children experience } \\
\text { in school. }\end{array}$ & $\begin{array}{l}\text { Finkelstein, } \\
\text { et.al, } 2002\end{array}$ & $\begin{array}{l}\text { 10. Explain how you involve the foster child's foster } \\
\text { family in the school environment. }\end{array}$ \\
\hline $\begin{array}{l}\text { There is a lack of } \\
\text { cooperation between } \\
\text { social workers \& } \\
\text { educators, along with } \\
\text { a level of mistrust }\end{array}$ & Christian, 2004 & $\begin{array}{l}\text { 11. What has been your experience in dealing with the } \\
\text { school social worker, child welfare or other agencies on } \\
\text { behalf of the foster children in school? }\end{array}$ \\
\hline $\begin{array}{l}\text { Foster children rarely } \\
\text { receive the services } \\
\text { needed to address } \\
\text { their unique needs }\end{array}$ & Kelly, 2002 & $\begin{array}{l}\text { 12. What strategies or interventions would you recommend } \\
\text { when working with foster children? }\end{array}$ \\
\hline
\end{tabular}




\section{Appendix G}

Concept Map of In-school Barriers

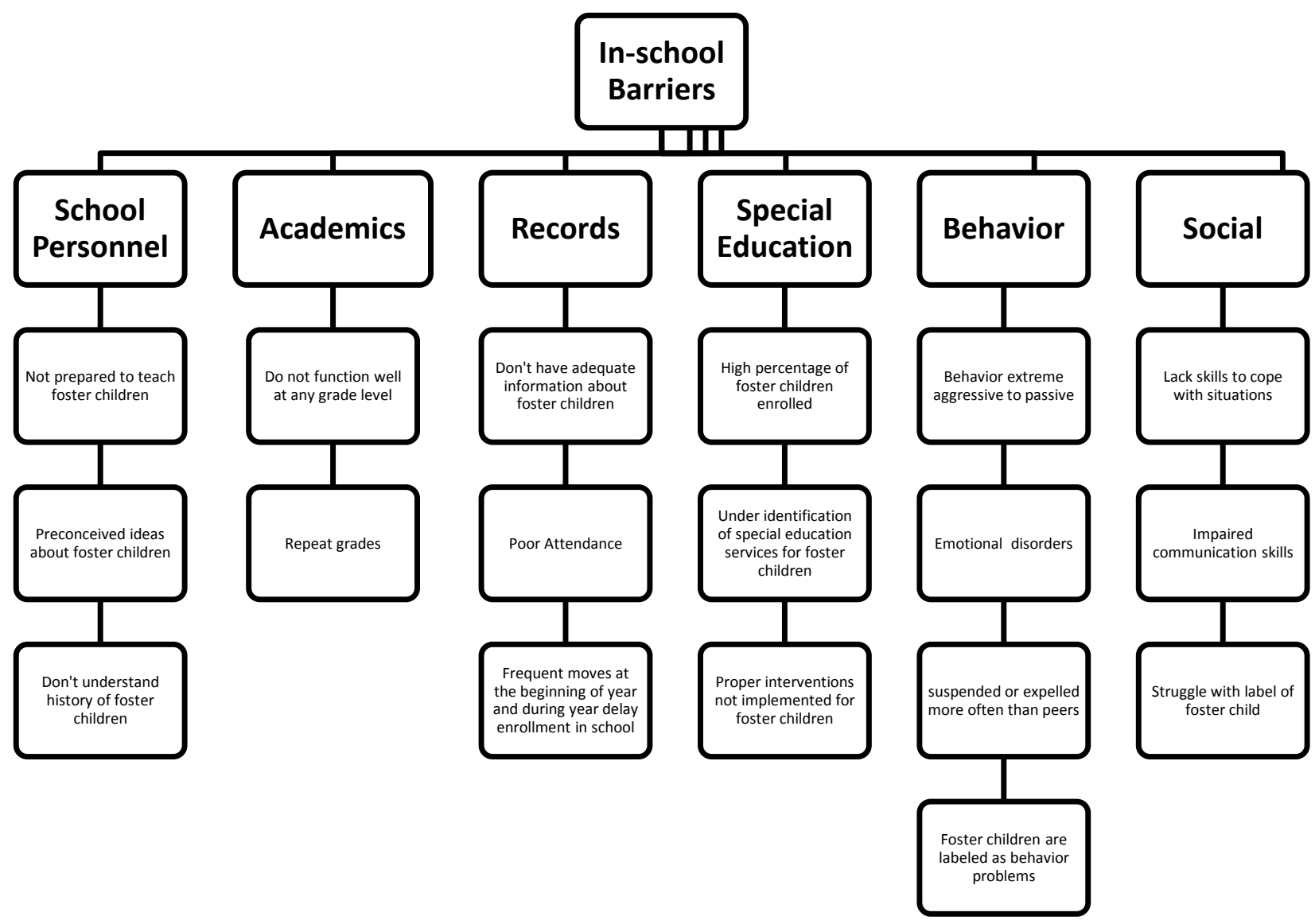


Appendix $\mathbf{H}$

Concept Map of Out-of-school Barriers

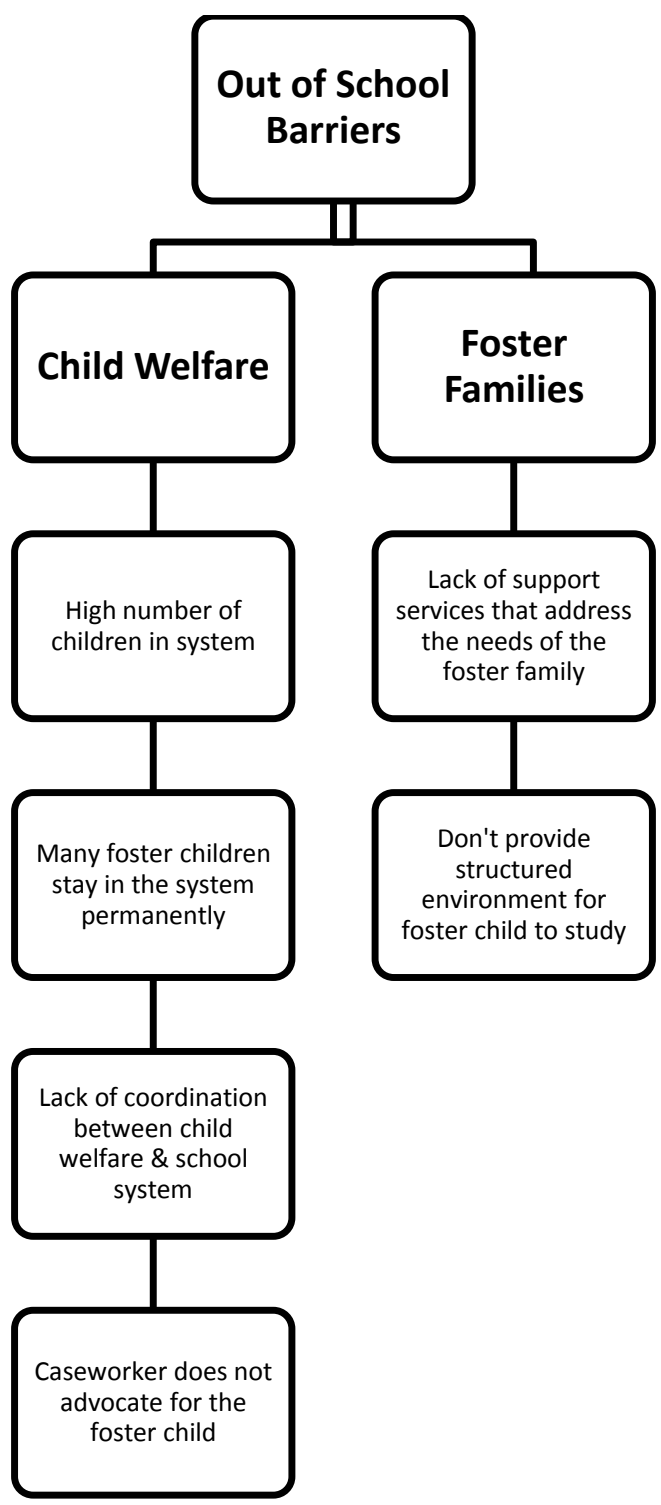




\section{Appendix I}

Directions to Panel of Experts Reviewing the Proposed Survey Instrument

\section{West Virginia Elementary School Principals' Perceptions of the Barriers that Interfere With the Delivery of Educational Services for Foster Children: The Lost At-Risk Children}

\section{Study Research Questions:}

- What barriers do principals in West Virginia Title I elementary schools perceive exist for foster children?

- Is there a relationship in the ratings of the Barriers in Educating Foster Children survey instrument as related to the demographics of the participants? The demographics are (2a) years of experience as a principal; (2b) years as principal at that school; (2c) gender; and (2d) RESA region?

- What experiences have principals in West Virginia Title I elementary schools had with foster children?

Directions: Please review the survey instrument West Virginia Elementary School Principals, Perceptions of the Barriers that Interfere with the Delivery of Educational Services for Foster Children: The Lost At-risk Children (attached). The invitation will be distributed via email to principals at 304 West Virginia elementary Title I schools. Those invited will receive a link to a URL hosting the survey instrument.

As you review the documents, please complete the attached response form following the directions provided at the top of the form. You will be asked to consider the following as you review the survey:

- Questions are direct and specific

- Only one question is asked at a time

- Participants can understand what is being asked

- Questions are concise

- The choices listed allow the participants to respond appropriately

- The questions are sufficient to address the problem in the study

- The questions are sufficient to answer the research questions

- Are there items that should be deleted? If so, please indicate

- Are there items that should be added? If so, please indicate

Please contact Janie DeVaul at jcdevaul@gmail.com or 304-657-1207 if you have any questions. Your input is valuable in improving the survey instrument. Please provide your feedback to jcdevaul@gmail.com no later than DATE

Thank you for taking the time to review this survey instrument 
APPENDIX J

SURVEY ITEM REVIEW 


\section{Survey Item Review}

\section{WV Elementary School Principal's Perceptions of the Barriers that Interfere with the Delivery of Educational Services for Foster Children: The Lost At-risk Children}

Directions: Please enter the word "Yes" or "No" in each space in the first three columns indicating your opinion of the item. In

Column 4, please indicate if the item should be kept, deleted, or modified. Please enter any comments or suggestions in Column 5.

\begin{tabular}{|c|c|c|c|c|c|}
\hline Item & $\begin{array}{c}\text { Column } 1 \\
\text { Clear \& easily } \\
\text { understood? }\end{array}$ & $\begin{array}{l}\text { Column } 2 \\
\text { Related } \\
\text { to topic \& } \\
\text { goals? } \\
\end{array}$ & $\begin{array}{l}\text { Column } 3 \\
\text { Important to } \\
\text { the research } \\
\text { aims? } \\
\end{array}$ & $\begin{array}{c}\text { Column } 4 \\
\text { Keep, Delete or } \\
\text { Modify? }\end{array}$ & $\begin{array}{c}\text { Column } 5 \\
\text { Comments or suggested modifications }\end{array}$ \\
\hline $\begin{array}{l}\text { Q1: Principals are not } \\
\text { prepared to meet the needs } \\
\text { of foster children }\end{array}$ & & & & & \\
\hline $\begin{array}{l}\text { Q2: Teachers are not } \\
\text { prepared to meet the needs } \\
\text { of foster children }\end{array}$ & & & & & \\
\hline $\begin{array}{l}\text { Q3: School staff have } \\
\text { preconceived ideas about } \\
\text { foster children }\end{array}$ & & & & & \\
\hline $\begin{array}{l}\text { Q4: Staff do not understand } \\
\text { the foster child's history in } \\
\text { school }\end{array}$ & & & & & \\
\hline $\begin{array}{l}\text { Q5: Foster children do not } \\
\text { function well at any grade } \\
\text { level }\end{array}$ & & & & & \\
\hline $\begin{array}{l}\text { Q6: Foster children tend to } \\
\text { repeat grade levels more }\end{array}$ & & & & & \\
\hline
\end{tabular}




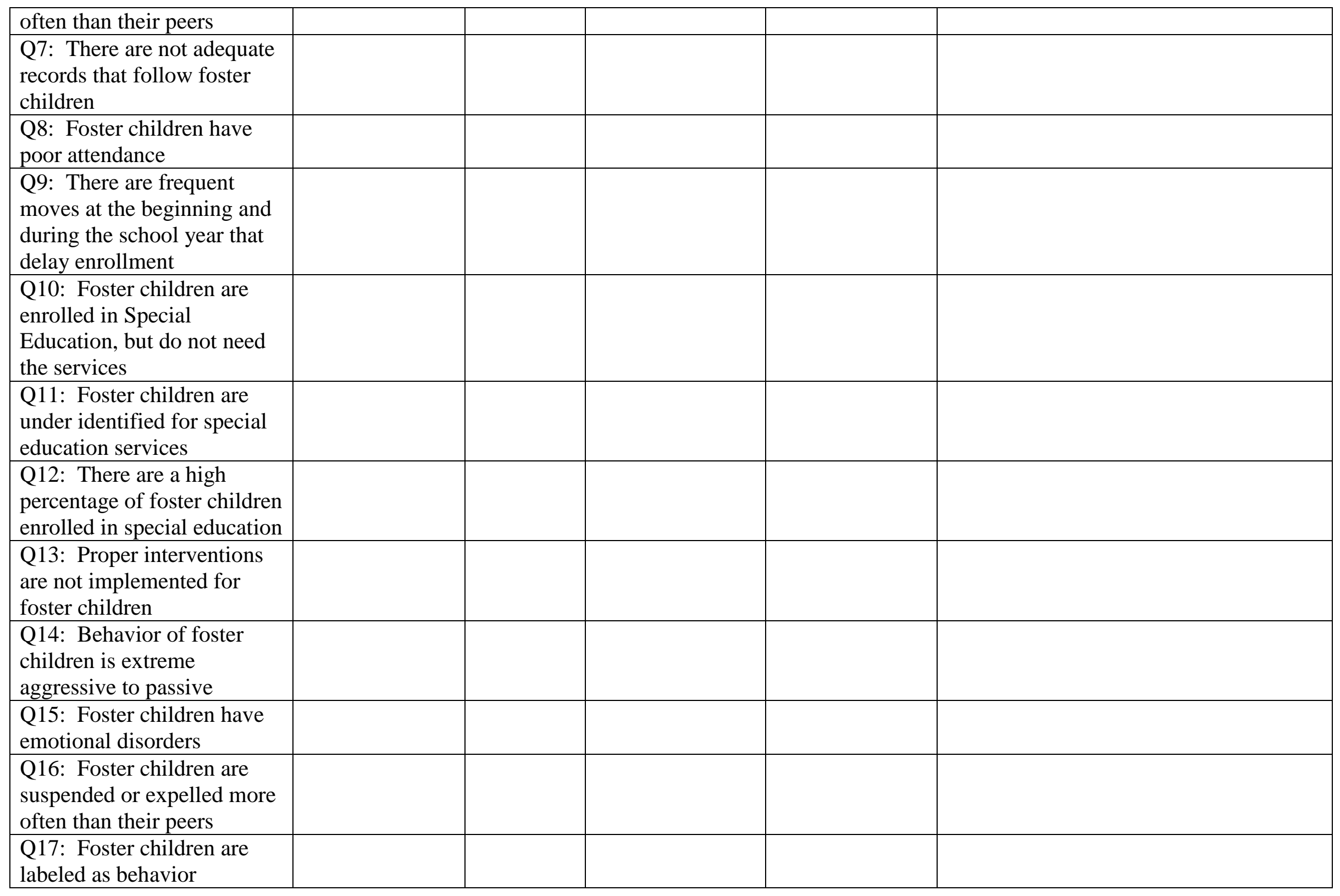




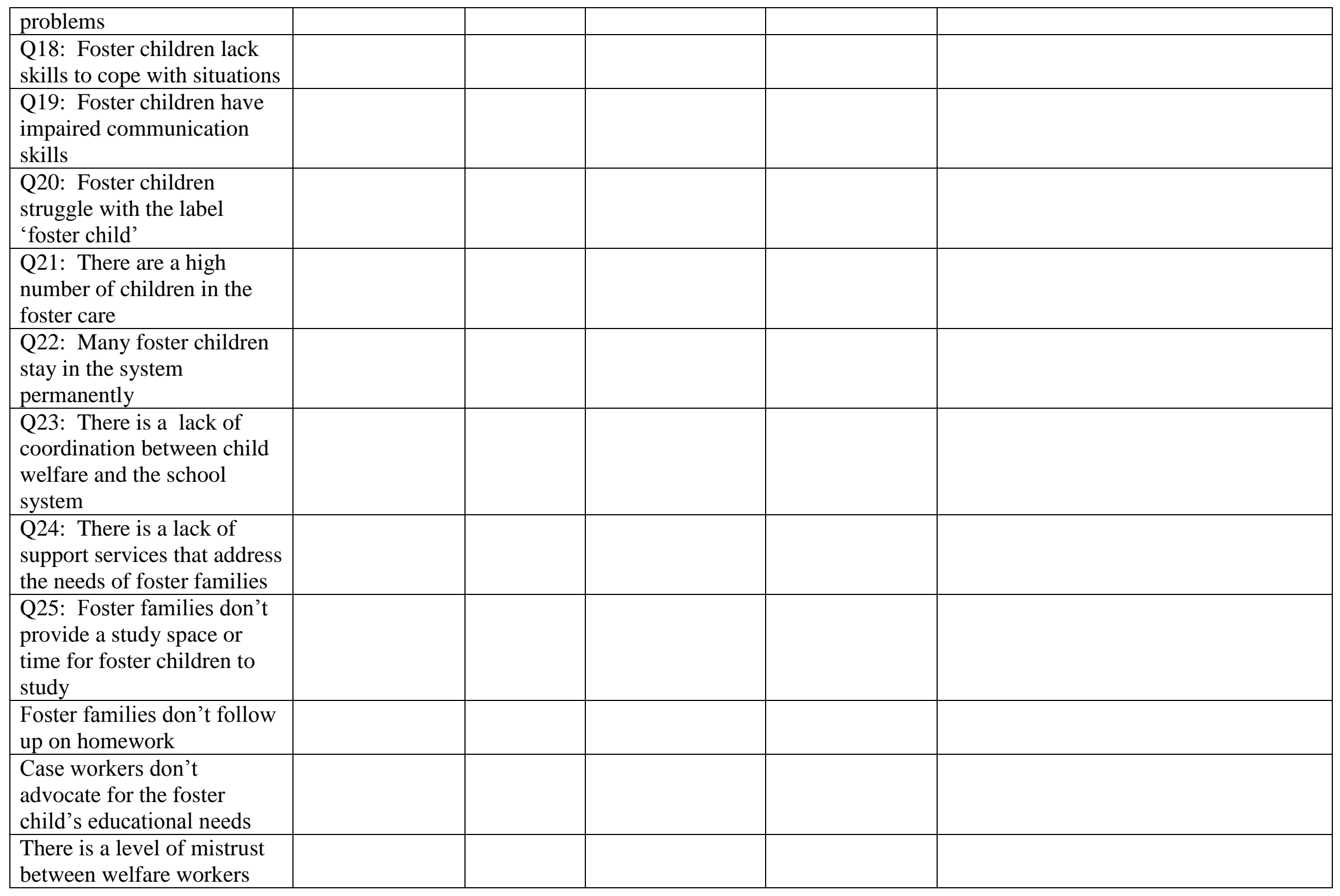




\begin{tabular}{|l|l|l|l|l|}
\hline and school principals & & & & \\
\hline $\begin{array}{l}\text { Have you had experiences } \\
\text { with foster children }\end{array}$ & & & & \\
\hline $\begin{array}{l}\text { How do you find out that } \\
\text { students in your school are } \\
\text { part of the foster care }\end{array}$ & & & & \\
system & & & & \\
\hline $\begin{array}{l}\text { How many foster children } \\
\text { are currently at your school }\end{array}$ & & & & \\
\hline $\begin{array}{l}\text { Would you like to be } \\
\text { interviewed }\end{array}$ & & & & \\
\hline
\end{tabular}

\section{Demographic Questions}

\begin{tabular}{|l|l|l|l|l|l|}
\hline \multicolumn{1}{|c|}{ Item } & $\begin{array}{c}\text { Column 1 } \\
\text { Clear \& easily } \\
\text { understood? }\end{array}$ & $\begin{array}{c}\text { Column 2 } \\
\text { Related } \\
\text { to topic \& } \\
\text { goals? }\end{array}$ & $\begin{array}{c}\text { Column 3 } \\
\text { Important to } \\
\text { the research } \\
\text { aims? }\end{array}$ & $\begin{array}{c}\text { Column 4 } \\
\text { Keep, Delete, } \\
\text { or Modify? }\end{array}$ & $\begin{array}{c}\text { Column 5 } \\
\text { Comments or suggested } \\
\text { modifications? }\end{array}$ \\
\hline $\begin{array}{l}\text { D1: What is your total } \\
\text { administrative experience }\end{array}$ & & & & \\
\hline $\begin{array}{l}\text { D2: What are your total } \\
\text { years as administrator in } \\
\text { this school }\end{array}$ & & & & & \\
\hline $\begin{array}{l}\text { D3: My gender is } \\
\text { male/female }\end{array}$ & & & & & \\
\hline $\begin{array}{l}\text { D4: In what RESA Region } \\
\text { are you located? }\end{array}$ & & & & \\
\hline
\end{tabular}


Appendix K

Superintendent Notification Letter 


\section{WestVirginiaUniversity}

College of Education and Human Services

October 2013

\section{Dear Superintendent:}

In partial fulfillment of the educational leadership studies doctoral program at West Virginia University, I am required to conduct a research-based study. The purpose of my study is to identify barriers, if any, that West Virginia Title I elementary school principals perceive interfere with the delivery of educational services to foster children in their schools. The data from this research could have an impact on how principals work with foster children.

The purpose of this letter is to inform you I will soon be contacting by email the principals at Title elementary schools seeking their participation in the study by completing an electronic survey. The survey will take less than 10 minutes of their time. Participation is voluntary and there are no consequences for non-participation. Respondents may skip any questions they are not comfortable answering or may quit at any point and submit a partially completed questionnaire. Individual survey responses will be kept confidential. Survey results will not indicate the identity of the participants or their respective schools.

Respondents are asked to complete the survey no later than DATE. If you have further questions contact me at jcdevaul@gmail.com or (304) 657-1207. Thank you for your assistance. Sincerely,

Helen M. Hazi, Ph.D.

Professor and Committee Chairperson
Janie C. DeVaul

Doctoral Candidate

\section{Department of Curriculum \& Instruction/Literacy \\ Program of Educational Leadership Studies \\ 608 Allen PO Box 6122 \\ Morgantown, WV 26506-6122}

Helen.Hazi@mail.wvu.edu

Phone: 304-293-1885 
Appendix L

Letter of Invitation to Participate in Survey 


\section{WestVirginiaUniversity}

Equal opportunity/Affirmative Action Institution

College of Education and Human

Services

October 2013

Dear Principal:

In partial fulfillment of the educational leadership studies doctoral program at West Virginia University, I am required to conduct a research-based study. The purpose of my study is to identify barriers, if any, that West Virginia Title I elementary school principals perceive interfere with the delivery of educational services to foster children in their schools. The data from this research could have an impact on how principals work with foster children.

The purpose of this letter is to seek your participation in the study by completing an electronic survey. The survey will take less than 10 minutes of your time. Your participation is voluntary and there are no consequences for non-participation. You may skip any questions you are not comfortable answering or may quit at any point and submit a partially completed questionnaire. Individual survey responses will be kept confidential. Survey results will not indicate the identity of the participants or your respective schools. West Virginia University's Institutional Review Board acknowledgement of this project is on file.

The online survey can be accessed at the following site: INCLUDE URL.

I sincerely appreciate your consideration regarding participation in this study. Please complete the survey no later than DATE. If you have further questions contact me at jcdevaul@ gmail.com or (304) 657-1207. Thank you for your assistance.

Sincerely,

Helen M. Hazi, Ph.D.

Professor and Committee Chairperson
Janie C. DeVaul

Doctoral Candidate

\section{Department of Curriculum \& Instruction/Literacy Program of Educational Leadership Studies 608 Allen PO Box 6122 \\ Morgantown, WV 26506-6122}

Helen.Hazi@mail.wvu.edu Phone: 304-293-1885 


\section{References}

Aldgate, J., Colton, M., Ghate, D., \& Heath, A. (1992). Educational attainment and stability in long-term foster care. Children in Psychology, 6(2), 91-103.

Allen, M. \& Bissell, M. (2004). Safety and stability for foster children: The policy context. Children, Families, and Foster Care, 14(1), 53-54.

Altshuler, S. (1997). A reveille for school social workers: Children in foster care need our help! Social Work in Education, 19(2), 121-127.

Altshuler, S. (2003). From barriers to successful collaboration: Public schools and child welfare working together. Social Work, 48(1), 52-63.

Antoine, K., \& Fisher, P. (2005). Preparing foster children for school. Educational Digest, 71(7), 61-63.

Avery, J. (2001). Education and children in foster care: Future success or failure? New Horizons for Learning. Seattle, WA. Retrieved November 15, 2011 from http://www.newhorizons.org

Baker, T. (1994). Doing Social Research. ( $2^{\text {nd }}$ Ed), New York: McGraw-Hill Inc. Retrieved from http://sru.soc.surrey.ac.uk/SRU35.HTML

Barahal, R., Waterman, J., \& Martin, H. (1981). The social-cognitive development of abused children. Journal of Consulting and Clinical Psychology, 49, 508-516.

Barbell, K. \& Freundlich, M. (2001). Foster Care Today. Washington, DC: Casey Family programs. Retrieved November 20, 2012 from http://www.hunter.cuny.edu/socwork/nrcfcpp/downloads/Policyissues/foster_care_today.pdf 
Barrat, V. \& Berliner, B. (2013). The Invisible Achievement Gap: Part I: Education outcomes of students in foster care in California's public schools. San Francisco: WestEd.

Barrier [Def. 2]. (2013). MacMillian dictionary online, retrieved March 19, 2013 from http://www.macmillandictionary.com/us/dictionary/american/barrier

Bass, S., Shield, M., \& Behaman, R. (2004). Children, families and foster care: Analysis and recommendations. Academic Journal 14(1), 5-29.

Beck, L. (1994). Reclaiming educational administration as a caring profession. New York: Teachers College Press.

Beck, L. \& Murphy, J. (1994). Understanding the principalship: Metaphorical themes, 1920s to 1990s. New York: Teachers College Press.

Begley, P. (2006). Self-knowledge, capacity and sensitivity: Prerequisites to authentic leadership by school principals. Journal of Educational Administration, 44(6), 570-589.

Berrick, J. (1998). When children cannot remain home: Foster family care and kinship care. Protecting Children From Abuse and Neglect, 8(1), 72-87.

Bevea, S. \& Nicoll, L. (1997). Selecting samples for research studies requires knowledge of the populations of interest. AORN Journal, 1-4. Retrieved December 18, 2012 from http://findarticles.com/p/articles/mi_mOFSL/is_n4_v66/ai_19996778/?tag=content;coll

Black, S. (2006). Fostering the right relationships. American School Board Journal, 50-52.

Blome, W. (1997). What happens to foster kids: Educational experiences of a random sample of foster care youth and a matched group of non-foster care youth. Child and Adolescent Social Work Journal, 14(1), 41-53.

Bolden, R., Gosling, J., \& Marturano, A., \& Dennison, P. (2003). A review of leadership theory and competency frameworks. Center for Leadership Studies. University of Exeter. 
Bonneau, L. (2003). School experiences of foster children as seen through the eyes of teachers (Doctoral dissertation). Retrieved July 19, 2010 from http://dspace.smith.edu/handle/.../browse?...Bonneau\%2C+Lynda\&type=author Brennen, A. (1994). Articles \& Resources on Educational Administration and Supervision. Retrieved April 15, 2011 from http://www.soencouragement.org/administration/

Brooks, J. \& Miles, M. (2006). From scientific management to social justice... and back again? Pedagogical shifts in the study and practice of educational leadership. International Electronic Journal for Leadership in Learning. 10(21). Retrieved October 2012 from http://www.ucalgary.ca/ iejll/

Brown, K. (2004). Loving the middle level. Principal Leadership (Middle School Edition) 4(5), $30-36$.

Bruskas, D. (2008). Children in foster care: A vulnerable population at risk. Journal of Child and Adolescent Psychiatric Nursing, 21(2), 70-77.

California Child Welfare Co-Investment Partnership (2011). Retrieved February 10, 2012 from http://www.google.com/search?q=california+child+welfare+coinvestment+partnership\% 2C+2011\&rlz=1C1CHLA_enUS459US459\&oq=california+child+welfare+coinvestment +partnership $+\% 2 \mathrm{C}+2011 \&$ aqs $=$ chrome $.0 .57 .243752 \&$ sugexp=chrome, mod=1\&sourceid $=$ chrome $\&$ ie $=$ UTF- 8

Calix, A. (2009). The effect of foster care experience and characteristics on educational outcomes (Doctoral dissertation). Retrieved from University of North Caroline: Chapel Hill.

Camras, L., Grow, J., \& Ribordy, S. (1983). Recognition of emotional expression by abused children. Journal of Clinical Child Psychology, 12, 325-328. 
Casey National Alumni Study. (2003). Assessing the effects of foster care: Results from the Casey National Alumni Study. Retrieved April 3, 2012, from http://www.casey.org/Resources/Publications/AssessingEffectsOfFosterCare.htm Child Trends (2011). Retrieved on February 12, 2012 from http://www.childtrends.org/Files/Child_Trends_2011_05_31_DS_FosterCare.pdg

Child Welfare Information Gateway (2011). Family reunification: What the evidence shows. Retrieved October 8, 2012, from http://www.childwelfare.gov/pubs/issue_briefs/family_reunification/family_reunification .pdf

Child Welfare League of America (2007). Education is the lifeline for youth in foster care. Retrieved February 1, 2013, from http://www.cwla.org/advocacy/NationalEdFactSheet2011.pdf

Children's Rights (2013). Facts About Foster Care. http://www.childrensrights.org/issuesresouces/foster-care/facts-about-foster-care/

Chipungu, S. \& Bent-Goodley, T. (2004). Meeting the challenges of contemporary foster care. Children, Families and Foster Care, 14(1). Retrieved January 18, 2013, from http://www.princeton.edu/futureofchildren/publications/journals/article/index.xml?journa lid $=40 \&$ articleid $-135 \&$ sectionid $=887$

Chisholm, G. (2010). Educational experiences that enhanced and impeded the academic outcome of youth in foster care (Doctoral dissertation). Retrieved from ProQuest Dissertations and Theses database. (UMI No. 3438132) 
Christian, S. (2003). Educating children in foster care. Washington, DC: National Conference of State Legislatures. Retrieved on July 18, 2010, from http://www.ncsl.org/Default.aspx?Tabld=4245

Christian, S. (2007). Educating children in foster care. Denver, CO: National Conference of State Legislatures. Retrieved July 23, 2012, from http://www.ncsl.org/programs/cyf/CPIeducate.htm

Coffin, D. (2008). Teacher perceptions of the changing role of the secondary middle school principal. Retrieved September 21, 2012, from http://scholarcommons.usf.edu/etd/182

Cohen, E. (1981). Sociology looks at team teaching. Research in Sociology of Education and Socialization, 2, 163-193.

Conducting Educational Research (n.d.). Identifying a Research Problem and Question. Retrieved January 15, 2013, from http://www.uk.sagepub.com/upmdata/36330_Chapter2.pdf

Conger, D., \& Finkelstein, M. (2003). Foster care and mobility. Journal of Negro Education, 72(1), 97-103.

Cormier, G. (1994). Increasing knowledge and assessment of foster care through in-service training for elementary school educators. ED.D. practicum report, Nova University, Ft. Lauderdale, FL.

Costin, L. \& Rapp, C. (1984). Child welfare policies and practices. New York: McGraw-Hill.

Couchman, W. \& Dawson, J. (1995). Nursing and health-care research, $2^{\text {nd }}$ ed. Scutari, London, UK. Retrieved December 15, 2012, from http://www.ruralhealth.utlas.edu.au/.../turnoch-and-gibson-action-research- 
Coughlan, M., Cronin, P., \& Ryan, F. (2007). Step-by-step guide to critiquing research. Part 1: quantitative research. British Journal of Nursing, 1(11). Retrieved March 22, 2011, from http://www.ncbi.nlm.nih.gov/pubmed/17577184

Courtney, M., Terao, S., \& Bost, N. (2004). Midwest evaluation of the adult functioning of former foster youth: Conditions of youth preparing to leave state care. Chicago, IL: Chapin Hall Center for Children at the University of Chicago.

Creswell, J. (1998). Qualitative inquiry and research design: Choosing among five traditions. London: Sage.

Creswell, J. (2004). Educational research: Planning, conducting, and evaluating quantitative and qualitative research. Columbus, $\mathrm{OH}$ : Merrill Prentice Hall.

Cronon, W. (2009). Learning how to do historical research: A primer how to frame a researchable question. Retrieved March 4, 2012, from http://www.williamcronon.net/researching/questions.htm

Crozier, J. \& Barth, R. (2005). Cognitive and academic functioning in maltreated children. National Association of Social Workers, 27(4), 197-206.

Daft, R. (2005). The leadership experience. Mason, OH: South-Western.

D'Ambrosio, M. (n.d.). Leadership in today's world. Navigating the currents of change. The Leader's role. The Annual International Congress on Challenges to Education: Balancing unity and diversity in a changing world. Retrieved June 22, 2012, from http://www.stanswartz.com/DAMBROSIO.htm

Danya International, Inc. (2003). The relationship between the research question, hypotheses, specific aims, and long-term goals of the project. The Research Assistant. Retrieved from http://www.theresearchassistant.com/tutorial/2-1.asp 
Darling-Hammond, L. (1998). Teacher learning that supports student learning. ASCD, 55(5).

Retrieved January 5, 2011, from http://www.ascd.org/publications/educationalleadership/feb98/vol55/num05/Teacher-Learning-That-Supports-Student-Learning.aspx

Data Snapshot (2011). Child Welfare Information Gateway. Retrieved March 18, 2013, from http://www.childwelfare.gov>Systemwide>Statistics

Dembowski, F. (2006). The Changing roles of leadership and management in education. Retrieved December 15, 2011, from http://cnx.org/content/m14280/latest/Dembowski.pdf.pdf

Dillman, D. (2006). Mail and internet surveys. $2^{\text {nd }}$ ed., New York: John Wiley and Sons.

DiPaola, M., \& Walther-Thomas, C. (2003). Principals and special education: The critical role of school leaders. Center on Personnel Studies in Special Education. University of Florida. Retrieved February 21, 2013, from http://copse.education.ufl.edu/docs/IB-7/1/1B-7.pdf

Downey, J. (2002). Perspectives on educational resilience from children facing adversity

(Doctoral dissertation). Retrieved from ProQuest Dissertations and Theses Database. (UMI No. 3059981)

Eckenrode, J., Rowe, E., Laird, M., \& Brathwaite, J. (1995). Mobility as a mediator of the effects of child maltreatment on academic performance. Child Development, 66, 1130-1142.

Educating Children in Foster Care (2008). National Conference of State Legislatures, 20042007. Retrieved August 5, 20122, from http://www.ncsl.org/print/cyf/foster_care_education.pdf

Ellerman, C. (2007). Influences on the mental health of children placed in foster care. Family Community Health, 30(25), 523-532. 
Emerson, J. \& Lovitt, T. (2003). The educational plight of foster children in schools and what can be done about it. Remedial and Social Education, 24(4), 199-203.

Eyre, T. (2005, August, 12). Foster children lost in schools, study says. West Virginia Gazette, p. $1 \mathrm{C}$.

Fergunson, C. (1999). The academic and school behavior outcomes of children in foster care: $A$ research synthesis (unpublished manuscript). University of California at Berkeley.

Finkelstein, M., Wamsley, M., \& Miranda, D. (2002). What keeps children in foster care from succeeding in school? Views of early adolescents and the adults in their lives. New York: Vera Institute of Justice. Retrieved October 26, 2010 from http://www.vera.org

Fletcher-Campbell, F. (1997). The education of children who are looked after. Slough, England: National Foundation for Educational Research.

Follett, M. (1924). Creative experience. Retrieved from http://archive.org/stream/creativeexperien00foll/creativeexperien00foll_djvu.txt

Foster Care Facts: West Virginia Child Welfare Policy. (2007). Retrieved from http://www.childwelfarepolicy.orgdoc/FCfacts.West\%20Virginia.pdf

Frerer, K., Sosenko, L., Pellegrin, N., Zakharenkov, A., Horowitz, J., \& Patton, M. (2011). First look: Foster youth educational outcomes in four California counties. Retrieved May 15, 2012, from http://www.stuartfoundation.org/Files/FirstLook_FullReport_Nov2011.pdf

Fricker, R. \& Schonlau, M. (2002). Advantages and disadvantages of internet research surveys: Evidence from the literature. Field Methods, 14(4), 347-67.

Gilligan, C. (1982). In a different voice: Psychological theory and women's development. Cambridge, MA: Harvard University Press. 
Gillian, R. (1999). The importance of schools and teachers in child welfare. Child and Family Social Work, 3, 13-25.

Glastone, R. (1981). The domestic dimensions of violence: Child abuse. Psychoanalytic Study of the Child, 36, 391-409.

Glanz, J. (2005). Action research as instructional supervision: Suggestions for principals. NASSP Bulletin, 89(643), 17-27.

Glanz, J. (2010). Justice and caring: Power, politics, and ethics in strategic leadership. ISEA, $38(1), 66-86$.

Glesne, C. (2006). Becoming qualitative researchers: An introduction. Boston, MA: Pearson and Allyn and Bacon.

Gliner, J. \& Morgan, G. (2000). Research methods in applied settings: An integrated approach to design and analysis. Mahwah, NJ: Lawrence Erlbaum Associates.

Goldring, E., \& Greenfield, W. (2002). Understanding the evolving concept of leadership in education: Roles, expectations, and dilemmas. In J. Murphy (Ed) The educational leadership challenge: Redefining leadership in the $21^{\text {st }}$ century, (pp 1-19). Chicago, IL: National Society for the Study of Education.

Gordon, S., Benner, Pl, \& Noddings, N. (1996). Caregiving: Readings in knowledge, practice, ethics, and politics. Philadelphia, PA: University of Pennsylvania Press.

Green, A. (1978). Psychiatric treatment of abused children. Journal of the American Academy of Psychoanalysis, 9, 435-446.

Green, R. (2001). Practicing the art of leadership: A problem-based approach to implementing the SLLC standards. Upper Saddle River, NJ: Merrill Prentice-Hall.

Greenburg, R. (1995). Promoting excellence in early childhood education. Principal, 74, 11-14. 
Gustavsson, N. (1991). The school and the maltreated child in foster care: A role for the school social worker. Social Work in Education, 13(4), 224-235.

Gustavsson, N. \& MacEachron, A. (2010). No foster child left behind: Child welfare policy perspectives on education. The Journal of Contemporary Social Services, 92(3), 276-281.

Gutman, D. (2013, September, 19). Poverty, stagnant incomes still prevalent in W.Va., Census report shows. West Virginia Gazette. Retrieved June 16, 2014, from www.wvgazett.com/News/201309190082

Hallinger, P. (2003). Leading educational change: Reflections on the practice of instructional and transformational leadership. Cambridge Journal of Education, 33(3), 329-351.

Halsey, V. (1996). Creating a school where people want to be. Thrust for Educational Leadership, 26(2), 25.

Handley, (2001). Validity and Reliability in Research. Retrieved on February 21, 2014, from http://www.natco1.org/Professional-Development/files/Research\%20Guidelines/ValidityReliability\%20Research\%20Article.pdf

Harden, B. (1998). Safety and stability for foster children: A developmental perspective. Children, Families, and Foster Care, 14(1). Retrieved on June 17, 2012 from http://www.futureofchildren.org

Hayes, C., Ryan, A., \& Zseller, E. (1994). The middle school child's perceptions of caring teachers. American Journal of Education, 103, 1-19

Herman, E. (2012). Fostering and foster care. The Adoption History Project. Retrieved June 18, 2012, from http://darwing.uoregon.edu/ adoption/topics/fostering.htm

Hine, G. (2003). Are American schools facing a shortage of qualified administrators? Catholic Education: A Journal of Inquiry and Practice, 7(2), 266-277. 
Hobbs, D. (1990). School based community development: Making connections for improved learning. In S. Raferty \& D. Mulkey (Ed.), The Role of Rural Schools in Community Development, (pp. 57-64). Mississippi State, MS. Southern Rural Development Center.

Hofstetter, C. (1999). Toward an equitable NAEP for English Language learners: What contextual factors affect math performance. Paper presented at the annual meeting of the American Educational Research Association, Montreal, Canada.

Hoppey, D. (2006). The man in the principal's office: Revisiting Harry Wolcott's research during an era of increased complexity and high stakes accountability (Doctoral dissertation). University of Florida.

International Program for Development Evaluation Training. (2007). Retrieved February 21, 2013 from http://www.worldbank.org/ieg/ipdet/modules.html

Irvine, J. (2001). Caring, competent teachers in complex classrooms. Washington, DC: American Association of Colleges for Teacher Education.

Jacobson, L. (2008). Schooling issues a complication for foster care. Education Week 27(41), 116.

Joftus, S. (2007). Educating Children in Foster Care: The McKinney-Vento and No Child Left Behind Acts. Retrieved October 1, 2012 from http://www.casey.org

Jenkins, L. (2009). Fundamentals of quantitative research. Retrieved March 19, 2011 from http://www.suite101.com/content/fundamentals-of-quantitative-research-al49406

Johnson, J., Livingston, M., Schwartz, R., \& Slate, J. (2000). What makes a good elementary school? A critical examination. The Journal of Educational Research, 93(3), 339-348. 
Julianelle, P. (2008). The McKinney-Vento Act and children and youth awaiting foster care placement. Strategies for improving educational outcomes through school stability. National Association for the Education of Homeless Children and Youth.

Kalla, S. (2011). Correlational Study. Retrieved on January 21, 2013 from http://explorable.com/correlational-study

Kaplan, L. \& Ownings, W. (2000). Helping kids feel safe, valued, and competent. The Education Digest, 66(3), 24-28.

Kasunic, M. (2005). Designing an Effective Survey. Software Engineering Measurement and Analysis. Retrieved from http://www.sei.cmu.edu/reports/05hb004.pdf

Keating, J. (2000). Education and foster care: A partnership model (Doctoral dissertation). Retrieved from ProQuest and Theses database. (UMI NO. 3199221)

Kellam, S. (2000). New school, new problems: Foster children struggle in U.S. schools. Connect for Kids. Retrieved April 2, 2010 from http://connectforkids.org/

Kelly, K. (2000). The education crisis for children in the California Juvenile Court System. Hastings Constitutional Law Quarterly, 27, 757-773.

Kendall-Tackett, K. \& Eckenrode, J. (1996). The effects of neglect on academic achievement and disciplinary problems: A developmental perspective. Child Abuse \& Neglect, 20, 161-169.

Kids Count (2010). State profiles on child well-being. Retrieved on February 5, 2011 from http://www.kidscount.org/KidData

King, B. (2006). Relationship of principal's leadership behavior to academic achievement and school improvement efforts (Doctoral dissertation). University of Maryland, College Park. 
King, L. (2010, September, 24). Study: Foster children struggle to learn. USA Today. Retrieved from http://usatoday30.usatoday.com/news/education/2010-09-23-foster-homes_Nhtm

Kinard, E. (1982). Experiencing child abuse: Effects on emotional adjustment. American Journal of Orthopsychiatry, 52, 82-91.

Kitchenham, B. \& Pfleeger, S. (2002). Principles of survey research. Software Engineering Notes, 28(2). Retrieved April 22, 2012 from http://www.idi.ntnu.no/grupper/su/publ/ese/kitcheham-survey6.pdf

Klugkist, I. (2008). Analysis of variance (ANOVA). In P. Lavarakas (Ed.), Encyclopedia of survey research methods (pp. 27-28). Thousand Oaks, CA: SAGE Publications.

Kools, S. \& Kennedy, C. (2003). Foster children health and development: Implications for primary care. Pediatric Nursing, 29(1), 39-46.

Kurtz, D., Gaudin, J., Howing, P., \& Wodarski, J. (1993). The Consequences of Physical Abuse and Neglect on the School Age Child: Mediating Factors. Children and Youth Services Review, 15, 85-104.

Larossi, G. (2006). The power of survey design: A user's guide for managing surveys, interpreting results, and influencing respondents. Washington, DC: The World Bank.

Lash, J. (2008). Understand qualitative vs. quantitative research. Retrieved May 15, 2012 http://www.goodproductmanager.com/2008/01/22/understand-qualitative-vsquantitativeresearch/

Levine, J. \& Ross, T. (1997). Introduction to data analysis: The rules of evidence. Retrieved April 18, 2012 from http://www.dartmouth.edu/ mss/docs/Volumes_1-2.pdf 
Lips, D. (2007). Foster care children need better educational opportunities. The Heritage Foundation, Leadership for America. Retrieved October 15, 2011 from http://www.heritage.org/research/education/bg2039.cfm

Loughborough University (2011). Questionnaire design. Retrieved April 17, 2012 from http://www.lboro.ac.uk/services/library/skills/topicslist/topic---questionnaire--design.html

Luneburg, F. (2010). Schools as open systems. National Forum Journals, Schooling 1(1). Retrieved January 8, 2012, from http://www.nationalforum.com/.../Lununburg,\%20Fred\%20C

Malhotra, N. (2004). Questionnaire design and scale development. Retrieved March 23, 2012 from http://www.terry.uga.edu/ rgrover/chapter_5pdf

Manning, E. (n.d.). Leadership v. management. Success Factory, Retrieved November 27, 2011 from http://www.successfactory.co/za/index2php?option=contentanddo_pdf=landid=43

Martin, G. \& Jenkins, S. (2008). Leadership eras. Lamar University, Beaumont, TX, Retrieved from http://degree.lamar.edu/documents/Week_4_Reading-Leadership_Eras.pdf

Mata, C. (2009). Academic achievement of foster children: Child welfare workers' perceptions and practices (Doctoral dissertation). California State University, Long Beach.

Matthews, L. \& Crow, G. (2003). Being and becoming a principal. Boston, MA: Pearson Education, Inc.

Mayeroff, M. (1971). On Caring. International Philosophical Quarterly, 5(3), 462-474.

McCullough, D. (1998). Assessing the reliability of statistical software: Part II. The American Statistician, 53,(2), 149-159. Retrieved on February 25, 2013 from http://www.pages.drexe.edu/ bdm25/tas2.pdf 
McKinney-Vento Homeless Education Act. (2001). Title X, Part C, of the Federal No Child Left Behind act, PL. 107-110, 42 U.S. code $\$ 11431$ et seq.

McNaught, K. (2005). Myth busting: Breaking down confidentiality and decision-making barriers to meet the educational needs of children in foster care. Washington, DC: American Bar Association Center on Children and the Law. Retrieved November 24, 2012 from http://www.aanet.org/child/rcji/education/caseyeducationproject.pdf

Mele', D. (2006). Ethics in management: Exploring the contribution of Mary Parker Follett. IESE Business School. University of Navarra.

Mendez, S. (2008). Support Networks and the Effect They Have on Foster Youth's Academic Success (Doctoral dissertation). Retrieved from Proquest Dissertations and Theses database. (UMI No. 1452550)

Merriam, S. (1998). Qualitative research and case study applications in education. San Francisco, CA: Jossey-Bass.

Miles, M. \& Huberman, M. (1994). An expanded sourcebook: Qualitative data analysis. Thousand Oaks, CA: Sage.

Miller, L. \& Smith, K. (1983). Handling nonresponse issues. Journal of Extension, 21(5), 4550. Retrieved from http://www.joe.org/joe/1983september/83-5-a7.pdf

Mohajeran, B. \& Ghaleei, A. (2008). Principal role and school structure. International Journal of Human and Social Sciences, 3(1). Retrieved November 18, 2012 from http://www.waset.org/journals/ijhss/v3/v3-1-7.pdf

Murphy, J. (1992). The landscape of leadership preparations: Reframing the education of school administrators. Newbury Park, CA: Corwin Press. 
Mydland, L. (2011). The legacy of one-room schoolhouse: A comparative study of the American Midwest and Norway. European Journal of American Studies. Retrieved July 12, 2012 from http://ejas.revues.org/9205

National Center for Mental Health Promotion and Youth Violence Prevention (2010). The Role of Schools in Supporting Children in Foster Care. Retrieved April 12, 2011 from http://www.promoteprevent.org

Nielsen, K., Randall, R., Yarker, J., \& Brenner, S. (2008). The effects of transformational leadership on followers' perceived work characteristics and psychological well-being: A longitudinal study. Work \& Stress, 22(1), 16-32.

Noble, L. (1997). The face of foster care. Educational Leadership, 55(8), 26-29.

No Child Left Behind Act (NCLB). Retrieved on April 28, 2012 from http://www.ed.gov/nclb/overview/intro/execsumm.html

Noddings, N. (1984). Caring: A feminine approach to ethics and moral education. Berkeley, CA: University of California Press.

Noddings, N. (1992). The challenge to care in schools: An alternative approach to education. New York: Teachers College Press.

O’Hare, W. (2008). Foster care vs. traditional. Annie E. Casey Foundation Study. Retrieved from http://www.aecf.org/ /media/PublicationFiles/FosterChildrenJuly2508.pdf

Palladino, J. (2006). Don't sell them dreams without the foundations: Collaboration for the transitional needs of foster care adolescents with disabilities. The High School Journal, 90(1), 22-32.

Patton, M. (1990). Qualitative evaluation and research methods, ( ${ }^{\text {nd }}$ ed.). Newbury Park, CA: Sage. 
Paulson, A. (2005). Fostering education. Christian Science Monitor. Retrieved from http://www.csmonitor.com/2005/0222/p15s01-legn.html

Pears, K., Fisher, P., \& Bronz, K. (2007). An intervention to promote social emotional school readiness in foster children: Preliminary outcomes from a pilot study. School Psychology Review, 36(4), 665-673.

The Pew Commission on Children in Foster Care. (2003). A Child's Journey Through the Child Welfare System. Retrieved October 26, 2010, from http://pewfostercare.org/research/docs/journey.pdf

Pfleeger, S. \& Kitcheham, B. (2001). Principles of survey research part 1: Turning lemons into lemonade. ACMSIGSOFT Software Engineering Notes, 26(6), 16-18. doi: $10.1145 / 505532.505535$

Phillips, J. (1996). Manager-Administrator to instructional leader: Shift in the role of the school principal. Retrieved April 9, 2012 from http://www.google.com/url?sa=t\&rct=j\&q=\&esrc=s\&source=web\&cd=33\&ved=OCCsQ FjACOB4\&url=http $\% 3 \mathrm{~A} \% 2 \mathrm{~F} \% \mathrm{Fwww}$.learningdomain.com\%2FPrincipalInstructLeader. htm\&ei=L4WDT-PKO8HgOQHs_sy1Bw\&usg=AFQjCNGtHco2iam18t1W11FDCyJSGpLcg\&sig2=FcnJnwSab8C2SzdN3vcAZw

Powell, E. (1998). Collecting evaluation data: Surveys. Program Development and Evaluation, University of Wisconsin-Extension. Retrieved March 3, 2012, from http://learningstore.uwex.ed/assets/pdfs/G3658-10.PDF

Powers, P. \& Stotland, J. (2002). Lost in the shuffle revisited. The education law center's report on the education of children in foster care in Pennsylvania. Retrieved February 22, 2012 
from http://www.elc-pa.org/pubs/downloads/english/dis-lost-in-the-shuffle-revisited-1202.pdf

Practical Assessment, Research \& Evaluation (1997). Retrieved May 2013 from http://pareonline.net.net

Professional Testing, Inc. (2006). Test validity. Retrieved March 20, 2012 from http://www.proftesting.com/test_topics/pdfs/test_quality_validity.pdf

Program Develoment \& Evaluation. (2006). University of Wisconsin-Extension. Retrieved from http://www.uwex.edu/ces/pdande/resources/pdf/tipsheet34.pdf

Radhakrishna, R. (2007). Tips for developing and testing questionnaires/instruments. Journal of Extension.45(1). Retrieved from http://www.joe.org/joe/2007february/tt2.php

Rand Corporation (n.d.). Who is leading our schools? Overview of current school administrators. Retrieved July 10, 2012 from http://www.rand.org/content/dam/rand/pubs/monograph_reports/MR1679.ch3.pdf Reaching Every Child (2005). Addressing educational attainment of out-of-home care children in West Virginia. West Virginia Out-of-Home Care Education Task Force. Retrieved January 12, 2013, from http://www.wvdhhr.org/oos_comm/reports/reaching\%20every\%20child\%20report\%2011 -23-05.pdf

Reynolds, T. (2011). Foster children: A hidden group. International Journal of Business and Social Services, 2(1), 44-50.

Robertson, T. (2009). Leadership theory vs. leadership style. Retrieved on April 21, 2012 from http://smallbusiness.chron.com.com/leadership-theory-vs-leadership-style-32967.html 
Rosnow, R. \& Rosenthal, R. (2008). Beginning behavioral research. Sixth Edition. Upper Saddle River, NJ: Prentice Hall.

Rossman, R. \& Rallis, S. (1998). Learning in the field: An introduction to qualitative research. Thousand Oaks, CA: Sage.

Rungtusanatham, M. (1998). Let's not overlook content validity. Decision Line, 29(4), 10-13.

Runyan, D. \& Gould, C. (1985). Foster care for child maltreatment: II. Impact on school performance. Pediatric, 72, 841-847.

Rush, S. \& Vitale, P. (1994). Analysis for determining factors that place students at-risk. Journal of Educational Research, 97(6), 325-333.

Santos, J. (1999). Cronbach's Alpha: A tool for assessing the reliability of scales. E-Journal of Extension Journal, 36(2). Retrieved from http://www.joe.org/joe/1999april/tt3.php.

Sawyer, R. \& Dubowitz, H. (1994). School performance of children in kinship care. Child Abuse and Neglect, 18(7), 587-597.

Sergiovanni, T. (1995). The principalship a reflective practice perspective. Boston, MA: Allyn and Bacon.

Schwartz, W. (1999). School support for foster families. New York: ERIC Clearinghouse on Urban Education.

Smithgall, C., Gladden, R., Yang, D., \& George, R. (2005). Behavior problems and educational disruptions among children in out-of-home car in Chicago. Chicago, IL: Chapin Hall Center for Children.

Southern Regional Education Board (2009). The district leadership challenge: Empowering principals to improve teaching and learning. Retrieved August 19, 2012 from http://www.sreb.org 
Spears, L. (2010). Character and servant leadership: Ten characteristics of effective, caring leaders. The Journal of virtues \& Leadership, 1(1), 25-30.

Stone, S. (2007). Child maltreatment, out-of-home placement and academic vulnerability: A fifteen year review of evidence and future directions. Children \& Youth Services Review 29(2), 139-161.

Stone, S., D’Andrade, A., \& Austin, M. (2007). Educational services for children in foster care: Common and contrasting perspectives of child welfare and education stakeholders. Journal of Public Child Welfare 1(2), 53-71.

Survey Monkey. (2011). Smart survey design. Retrieved from http://s3.amazonaws.com/SurveyMonkeyFiles/SmartSurvey.pdf

Suskie, L. (1996). Survey research: What works for the institutional researcher? Ithaca, NY: Northeast Association for Institutional Research.

The Federal Child \& Family Services Review (2001). Training of child welfare staff and providers. Protecting Children 19, 4-14. Retrieved October 25, 2012 from http://www.childwelfare.gov/management/reform/cfsr/findings.cfm

Thurlow, M. (2000). Standards-based reform and students with disabilities: Reflections on a decade of change. Focus on Exceptional Children 32(1). Retrieved January 25, 2013, from www.personnelcenter.org/pdf/copsse_principals.pdf

Trochim, W. (2006). Internal consistency reliability. Retrieved March 28, 2012 from http://www.socialresearchmethods.net/kb/reltypes.php

University of Leeds (2011). Guide to the design of questionnaires. Retrieved February 22, 2012 from http://iss.leeds.ac.uk/info/312/surveys/217/ 
University of Wisconsin (2006). Program Development \& Evaluation. Retrieved May 2013 from http://www.uwex.edu/ces/pdande/resources/pdf/Tipsheet34.pdf

U.S. Department of Education. (2011). No Child Left Behind, A Reauthorization of the Elementary and Secondary Act. Washington, DC: U.S. Department of Education.

U.S. Department of Health \& Human Services Administration for Children \& Families (2008). Trends in foster care and adoption. Retrieved May 25, 2011 from http://www.acf.hhs.gov/programs/cb/cwmonitoring/tools_guide/statewidethree.htm

Vacca, J. (2004). No child left behind...except the foster child. Relational Child \& Youth Care Practice, 20(2), 67-73.

Vacca, J. (2008). Breaking the cycle of academic failure for foster children - what can the schools do to help? Children and Youth Services Review, 30(9), 1081-1087.

Vera Institute of Justice. (1999-2002). Foster children \& education: How can you create a positive educational experience for the foster child. Retrieved October 1, 2012 from http://www.ytfg.org/documents/241_452.pdf

Vesecky, S., Woodard, S., \& Levine, A. (2005). California Foster Care Education Law Fact Sheets. Retrieved November 12, 2011 from http://www.casey.org Washington State Institute For Public Policy (2008). Evidence-based programs to prevent children from entering and remaining in the Child Welfare System: Benefits and costs for Washington. Retrieved May 5, 2012 from http://www.wsipp.wa.gov/rptfiles/08/073901.pdf

Watson-Davis, D. (2010). Teacher's understanding, perceptions, and experiences of students in foster care: A forgotten population (Doctoral dissertation). Retrieved from ProQuest Dissertations and Theses database. (UMI No. 3399119) 
Weinberg, L., Zetlin, A., \& Shea, N. (2006). Improving educational prospects for youth in foster care: The educational prospects for youth in foster care: The Educational Liaison Model. Intervention in Schools and Clinics, 41(5), 267-272.

West Virginia Department of Education (2014). Title I Homeless. Retrieved June 16, 2014, from wvde.state.wv.us/titlei/homeless.html

West Virginia Department of Health of Human Resources Bureau for Children and Families (2005). Retrieved on May 25, 2012 from http://www.wvdhhr.org/bcf/

West Virginia Out-of-Home Care Educational Task Force (2005). Reaching Every Child: Addressing educational attainment of out-of-home care children in West Virginia. Retrieved June 30, 2012 from http://www.wvdhhr.org/oss_comm/reports/reaching\%20every\%20child\%20report\%2011 -23-05.pdf

Witt, M. (2007). Mary Parker Follett: Retrospect \& Prospect. Paper presented at CMSS Conference: Management \& Organization History Stream. University of La Verne, La Verne, CA.

Wolinski, S. (2010). Leadership Theories. Retrieved April 21, 2012 from http://managementhelp.org/blogs/leadership/2010/04/21/leadership-theories/

Yount, D. (2006). Survey research: The questionnaire, the interview, and developing a survey instrument. Retrieved May 5, 2012 from http://www.napce.org/documents/researchdesign-young/10_survey_4th.pdf

Yukl, G. (1989). Managerial leadership: A review of theory and research. Journal of Management, 15(2), 251-288. 
Zetlin, A. (2006). The experiences of foster children and youth in special education. Journal of Intellectual \& Developmental Disability, 31(3), 161-165.

Zetlin, A. \& Weinberg, L. (2004). Understanding the plight of foster youth and improving their educational opportunities. Child Abuse \& Neglect, 28(9), 917-923.

Zetlin, A., Weinberg, L., \& Kimm, C. (2003). Are the educational needs of children in foster care being addressed? Children \& Schools, 25(2), 105-119.

Zetlin, A., Weinberg, L., \& Kimm, C. (2004). Improving education outcomes for children in foster care: Intervention by an education liaison. Journal of Education for Students Placed at Risk 9(4), 421-429.

Zetlin, A., Weinberg, L., \& Kimm, C. (2005). Helping social workers address the educational needs of foster children. Child Abuse and Neglect, 29(7), 811-823.

Zetlin, A., Weinberg, L., \& Shea, N. (2006). Seeing the whole picture: Views from diverse participants on barriers to educating foster youths. Children and Schools, 28(3), 156-173. 